Aus dem Institut für Tierphysiologie und Tierernährung der Georg-August-Universität Göttingen

\title{
Organic farming and the impact of fiber-related digestive processes in pigs
}

\author{
Dissertation \\ zur Erlangung des Doktorgrades \\ der Fakultät für Agrarwissenschaften \\ der Georg- August-Universität zu Göttingen
}

vorgelegt von

Elke Meister

geboren in Langen/Offenbach

Göttingen, November 2004 
D7

Referent:

Prof. Dr. Hj. Abel

Korreferent:

Prof. Dr. G. Breves

Tag der mündlichen Prüfung: $\quad$ November 2004 


\section{TABLE OF CONTENTS}

$\begin{array}{ll}\text { 1.Introduction } & 1\end{array}$

2.Literature Review 3

2.1 Plant composition 3

2.1.1 Dry matter 3

2.1.2 Protein 3

2.1.3 Carbohydrates 5

$\begin{array}{ll}\text { 2.2 Physiological effects of fiber-rich organic feedstuff } & 6\end{array}$

2.2.1 Degradation of NSP 6

2.2.1.1 General 6

2.2.1.2 Degradation of NSP in the digestive tract 7

2.2.1.3 Microbial growth and microbial activity 9

2.2.1.4 SCFA production in the digestive tract $\quad 10$

$\begin{array}{ll}\text { 2.2.1.5 Influence of NSP on energy metabolism } & 12\end{array}$

2.2.2 Influence of NSP on the digestion and absorption of other nutrients $\quad 14$

2.2.2.1 Influence of NSP on passage time during the gastrointestinal tract $\quad 14$

2.2.2.2 Influence of NSP on digestion of starch and sugar 16

$\begin{array}{ll}\text { 2.2.2.3 Influence of NSP on protein digestion } & 16\end{array}$

$\begin{array}{ll}\text { 2.2.2.4 Influence of NSP on fat digestion } & 18\end{array}$

$\begin{array}{ll}\text { 2.2.2.5 Influence of NSP on mineral absorption } & 20\end{array}$

$\begin{array}{ll}\text { 3. Studies } & 22\end{array}$

Study 1: Nutritional properties of organically and conventionally grown cultivars of wheat, barley and faba beans

1. Introduction 22

2. Material and methods 23

3. Results 25

4. Discussion 27

$\begin{array}{ll}\text { 5. References } & 30\end{array}$ 
Study 2: Fiber-related digestive processes in different breeds of pigs

1. Introduction

2. Material and methods

3. Results 38

4. Discussion 42

5. References

Study 3: Influence of sugar beet pulp addition on fermentation characteristics in different pig breeds using the Colon Simulation Technique (COSITEC)

1. Introduction 52

2. Material and methods 53

3. Results 57

4. Discussion 61

5. References 64

Study 4: The use of microcalorimetry to determine microbial activity in caecum content of pigs fed diets differing in BFS content

1. Introduction 67

2. Material and methods 68

3. Results 70

4.Discussion 72

5. References 74

Study 5: Influence of dietary SBP supplement on electrophysiological parameters in pigs determined with the Ussing chamber technique

1. Introduction

2. Material and methods 76

3. Results 79

4. Discussion 83

5. References 84 
Study 6: Influence of feeding diets of organically or conventionally produced food components on digestive processes in different pig breeds

1. Introduction

2. Material and methods 88

3. Results 90

4. Discussion 93

5. References 95

4. General Discussion 100

5 Summary 103

6. Zusammenfassung 104

7. References 106 


\section{LIST OF TABLES}

\section{Literature review}

Table 1: Crude protein content of organically and conventionally produced cereals (\% DM)

Table 2: $\quad$ Starch content of organically and conventionally produced cereals $(\% \mathrm{DM}) \quad 6$

Table 3: Digested polysaccharides (\%) in ileum and feces in dependence of the dietary oat fraction according to BACH KNUDSEN et al. (1993b)

Table 4: Concentration of different fatty acids in the intestine content of pigs ( $\mathrm{mg} / \mathrm{g}$ gut content) in dependence of NSP source according to FREIRE et al. (2000; modified)

Study 1: Nutritional properties of organically and conventionally grown cultivars of wheat, barley and faba beans

Table 1: Starch content in wheat, barley and faba beans of conventional and organic cultivation (\% DM)

Table 2: Pentosan content in wheat of conventional and organic cultivation (\% DM)

\section{Study 2: Fiber-related digestive processes in different breeds of pigs}

Table 1: Components of the experimental diets (\%)

Table 2: DM content (\%) and ingredients (\% DM) of the experimental diets

Table 3: Influence of diet and pig breed on bulking properties and WHC (g water/g DM) in different intestinal parts

Table 4: Influence of diet and pig breed on nutrient digestibility (\%)

Table 5: Influence of diet and pig breed on the amount of consumed and digested fiber $\left(\mathrm{g} / \mathrm{kg}^{0.75}\right)$ and on fiber digestibility $(\%)$

Table 6: Influence of diet and pig breed on N-balances during metabolism trial

Table 7: Influence of diet and pig breed on total $\mathrm{N}\left(\mathrm{g} / \mathrm{d}^{*} \mathrm{~kg}^{0.75}\right)$, on the amount and proportion (\%) of $1 \mathrm{~N}$-fractions and on the amount of BP ( $\mathrm{g}$ per $100 \mathrm{~g}$ BFS) in feces.

Table 8: Influence of diet and breed on urea and creatinin excretion in urine $\left(\mathrm{g} / \mathrm{d}^{*} \mathrm{~kg}^{0,75}\right) 41$

Table 9: Influence of diet and breed on mineral balances

Study 3: Influence of sugar beet pulp addition on fermentation characteristics in different pig breeds using the Colon Simulation Technique (COSITEC)

Table 1: Components of the experimental diets (\%)

Table 2: $\quad$ DM content (\%) and ingredients (\% DM) of the experimental diets 54

Table 3: Composition of artificial buffer (mmol/l) 55

Table 4: External standard for analysis of short chain fatty acids $\quad 57$

Table 5: Influence of diet and pig breed on input, disappeared nutrients and nutrient disappearance in the COSITEC

Table 6: Influence of diet and breed on input, disappeared nutrients and nutrient disappearance in the COSITEC: differentiation of interaction cases 
Table 7: Influence of diet and pig breed on SCFA production in the COSITEC:

differentiation of the interaction cases $(\mathrm{mmol} / \mathrm{d})$

Table 8: Influence of diet and pig breed on the production of fermentation gases (mmol/d) during COSITEC

Table 9: Influence of diet and pig breed on hydrogen balances

Table 10: Influences of diet and pig breed on hydrogen balances: differentiation of the interaction cases

Study 4: The use of microcalorimetry to determine microbial activity in caecum content of pigs fed diets differing in BFS content

Table 1: Components of the experimental diets (\%)

Table 2: $\quad$ DM content $(\%)$ and ingredients (\%DM) of experimental diets

Table 3: Influence of the repetition on energy production $(\mathrm{J} / \mathrm{gDM})$ and on average heat production $(\mathrm{mW} / \mathrm{gDM})$

Table 4: Influence of diet and breed on energy and average heat production of caecum content

Study 5: Influence of dietary SBP supplement on electrophysiological parameters in pigs determined with the Ussing chamber technique

Table 1: Components of the experimental diets (\%)

Table 2: $\quad$ DM content (\%) and ingredients (\% DM) of experimental diets

Table 3: Composition of serosal and mucosal buffer solution used in the Ussing chamber (mmol/l)

Study 6: Influence of feeding diets of organically or conventionally produced feed components on digestive processes in different pig breeds

Table 1: Components of the experimental diets (\%)

Table 2: Content DM (\%) and ingredients (\% DM) of the experimental diets

Table 3: Influence of diet and pig breed on nutrient digestibility (\%)

Table 4: Influence of diet and breed on N-balances during metabolism trial

Table 5: Influence of diet and pig breed on mineral balances 


\section{LIST OF FIGURES}

\section{Literature review}

Figure 1: NSP (Glucose)- and Arabinoxylan-concentration (g/kg DM) in different sections of the digestive tract of pigs according to BACH KNUDSEN (1993b) (I: Ileum; Ce: Caecum; C1: proximal Colon, C2 and C3: ascending Colon; C4 and C5: descending Colon; C6: distal Colon)

Study 1: Nutritional properties of organically and conventionally grown cultivars of wheat, barley and faba beans

Figure 1: Influence of the cultivation method on crude protein content in wheat,barley and faba beans ( $\%$ of DM)

Figure 2: Influence of cultivation method on NDF content in wheat, barley and faba beans (\% of DM)

Figure 3: Influence of cultivation method on ADF content in wheat, barley and faba beans $(\%$ of $\mathrm{DM})$

Study 4: The use of microcalorimetry to determine microbial activity in caecum content of pigs fed diets differing in BFS content

Figure 1: Heat production of caecum content from pigs fed the basal diet or the SBP diet. 71

Figure 2: Heat production of caecum content of different pig breeds independent of the feed type

Study 5: Influence of dietary SBP supplement on electrophysiological parameters in pigs determined with the Ussing chamber technique

Figure 1: Influence of diet and breed on the short circuit current in the jejunal mucosa. 80

Figure 2: Influence of diet on the short circuit current in the colon mucosa on the example of SH pigs

Figure 3: Influence of diet and breed on the tissue conductance in the jejunal mucosa $\quad 82$

Figure 4: Influence of the diet on the tissue conductance in the colon mucosa on the example of SH pigs 


\section{APPENDIX}

\section{Study 1}

Table 1: $\quad$ Means of protein content (\% DM) in different plant species 116

Table 2: $\quad$ Means of NDF content (\% DM) in different plant species 116

Table 3: $\quad$ Means of ADF content (\% DM) in different plant species 116

\section{Study 2}

Table 4: Amino acid content in the diets

Table 5: Influence of diet and pig breed on nutrient intake and fecal excretion $\left(\mathrm{mg} / \mathrm{d}^{*} \mathrm{~kg}^{0,75}\right)$

Table 6: Influence of diet and pig breed on mineral balances $\left(\mathrm{mg} / \mathrm{d}^{*} \mathrm{~kg}^{0,75}\right)$

\section{Study 3}

Table 7: Influence of diet and pig breed on SCFA production

\section{Study 5}

Table 9: Short circuit current in jejunal mucosa $\left(\mu \mathrm{Eq} / \mathrm{cm}^{2} / \mathrm{h}\right)$

Table 10: Short circuit current in the colon mucosa $\left(\mu \mathrm{Eq} / \mathrm{cm}^{2} / \mathrm{h}\right)$

Table 11: Tissue conductance in the jejunal mucosa $\left(\mathrm{mS} / \mathrm{cm}^{2}\right)$

Table 12: Tissue conductance in the colon mucosa $\left(\mathrm{mS} / \mathrm{cm}^{2}\right)$

\section{Study 6}

Table 13: Influence of diet and pig breed on nutrient intake and fecal excretion $\left(\mathrm{mg} / \mathrm{d}^{*} \mathrm{~kg}^{0,75}\right)$ 


\section{LIST OF ABBREVIATIONS}

\begin{tabular}{ll} 
AA & Amino Acid \\
ADF & Acid Detergent Fiber \\
ADL & Acid Detergent Lignin \\
AEC & Adenylate Energy Charge \\
Ala & Alanine \\
Arg & Arginine \\
Asp & Asparagine \\
ATP & Adenosine Triphosphate \\
BB & Buntes Bentheimer Schwein \\
BEDN & Bacterial and endogenous debris nitrogen \\
BFS & Bacterially fermentable substrate \\
BP & Bacterial protein \\
C & Carbohydrate \\
CA & Crude ash \\
CB & Crossbreed pig \\
CF & Crude fiber \\
ch. & chamber \\
conv. & conventional \\
COSITEC & Colon Simulation Technique \\
CP & Crude protein \\
Cys & Cystine \\
DM & Dry matter \\
EE & Ether extract \\
Glu & Glutamic acid \\
Gly & Glycine \\
His & Histidine \\
Ile & Isoleucine \\
Leu & Leucine \\
Lys & Lysine \\
ME & Metabolizable energy \\
Met & Methionine \\
N & Nitrogen \\
NDF & Neutral detergent fiber \\
NfE & N-free extract \\
NSP & Non-Starch-Polysaccharides \\
OM & Organic matter \\
org. & organic \\
p & Probability \\
Phe & Phenylalanine \\
Pro & Proline \\
SBP & Sugar beet pulp \\
SCFA & Short chain fatty acid \\
SD & Standard deviation \\
SEM & Standard error means \\
Ser & Serine \\
SH & Schwäbisch Hällisches Schwein \\
Sig. & Significance \\
Thr & Threonine \\
Tyr & Tyrosine \\
\hline &
\end{tabular}


UDN Undigested dietary nitrogen

Val Valin

WHC Water holding capacity

WSN Water soluble nitrogen 


\section{Introduction}

Organically produced feedstuffs are products being cultivated under controlled production conditions regulated by the EC-Regulation on organic farming (Regulation (EWG) 2092/91) and its supplementary ordinances as well as by different nationally organic farming associations being organized in the International Federation of Organic Movements (IFOAM). Caused by the guidelines of the different organic associations, production terms of organic farming are different from those usual in conventionally farming. Soil fertility should almost exclusively be achieved by humus management and crop rotation. Only in special cases home-produced organic manure is allowed to be mixed with other manures or commercial organic or mineral fertilizers. The use of easily soluble mineral fertilizers is forbidden. Plant protection is achieved by adapted crop rotation and fertilization and thus promoting the plant`s own defense mechanisms as well as by the use of special breeds. The use of synthetic pesticides, growth regulators and herbicides is not allowed. (BUNDESMINISTERIUM FÜR VERBRAUCHERSCHUTZ, ERNÄHRUNG UND LANDWIRTSCHAFT, 2002; BIOLAND, 2001; DEMETER, 2002; NATURLAND, 2002).

It is supposed, that lower nutrient availability and the lack of chemical plant protection in organic farming lead to different ripening processes and thus to a different composition of nutrients and other plant ingredients between organically and conventionally produced feedstuff (BRANDT \& MølgaARD, 2001), which could be shown in the very few earlier studies on this topic (WOESE, 1995).

Feeding regulations in organic animal production, which stipulate daily availability of roughage for every porker and breeding-pig according to age, could lead to higher levels of dietary fiber in organic pig diets compared to conventional ones.

Pigs do not have the ability to break down Non-Starch Polysaccharides (NSP) due to a lack of the endogenous enzymes, which normally perform this function. Therefore these components, mostly consisting of cellulose, hemicelluloses and lignin, need to be fermented by microbes in the intestinal tract of the animals. This means, NSP are present during most digestive processes along with other nutrients such as sugar, starch, protein and fat and consequently do affect these processes (BAKKER et al., 1998). Many experiments, carried out with different kinds of fibers, have shown this mainly negative influence of NSP on digestion and absorption of other nutrients and minerals.

Consequent selection on high daily body weight gains and high feed utilization with feeding concentrated feedstuff may have changed the ability for fiber degradation by morphological 
and physiological changes in the digestive tract of modern pig breeds. As NSP are known to be mainly fermented in the hindgut, changes in the digestive tract may result in a less effective break down of these components and a less efficient utilization for modern pig breeds compared to older ones.

The aim of this study was to test the following hypotheses:

- Compared to conventional diets, organic diets contain higher amounts of Non-Starch Polysaccharides (NSP) as a result of current production guidelines and thus changes in ripening processes and as a result of special feeding regulations.

- $\quad$ Feeding high-fiber instead of low-fiber feedstuff results in distinguishable nutritionphysiological differences, which are verifiable by digestive-physiological parameters.

- Old pig breeds differ from modern crossbreed pigs in their genetic disposition for hindgut digestion and are more appropriate to utilize fiber-rich organic diets.

Therefore organically and conventionally cultivated feedstuff was analyzed for its plant-based ingredients. Subsequently, the influence of elevated dietary NSP contents on digestive physiology in the pigs was investigated in metabolic trials and by means of the colon simulation technique (COSITEC). Furthermore, the effects of elevated NSP contents in the diet on intestinal, mucosal membrane function and resorption processes were analyzed using the Ussing chamber technique. 


\section{Literature Review}

\subsection{Plant composition}

Owing to different growing conditions in organic and conventional farming systems it could be possible that there are differences in plant composition between organically and conventionally produced plant products. In particular, crude protein and skeleton substances are expected to be strongly influenced by the production method. Unfortunately the number of investigations carried out considering this theme is limited. Only a few authors give details about nutrient composition of organically or conventionally produced products. Most literature sources are compared to agricultural development quite old. It may therefore be concluded that the results been found are not consistent with actual conditions in agricultural production. Recent literature concerning this theme (WOESE et al., 1995; WORTHINGTON, 1998; WILLIAMS, 2002; KUMPULAINEN, 2001) is mostly summaries or evaluations of literature being published in the $60^{\text {th }}$ - to $80^{\text {th }}$. Therefore these literature sources also show a lot of overlaps. Very often compared plants were not produced under the same conditions of climate and soil. Different regulations of the respective organic associations lead to a lack of comparability (ALFÖLDI, 1998).

\subsubsection{Dry matter}

It could be assumed that conventionally and organically cultivated products caused by different growing conditions and thus changes in ripening processes differ in their dry matter content (MøLGAARD, 2000). However, there were only few hints found concerning this theme showing an approximate $5-40 \%$ elevation in dry matter content compared to conventional products, but mostly in organic produced vegetable (ANDERSEN et al., 2001; WILLIAMS, 2002).

\subsubsection{Protein}

\section{Protein content}

Depending on the cultivation method and selected fertilization method (organic or mineral), plant protein content and protein composition can be influenced. Higher nitrogen application 
or faster availability of fertilizer bound nitrogen causes higher protein content (DELGADO et al., 1999). As only organic manure is allowed in organic farming, it can be assumed that the content of direct plant-available nitrogen is lower than in conventional farming. This would result in reduced nitrogen content in plants.

This assumption is confirmed in most studies showing a reduced protein content for organic cultivated products compared to conventional ones, independent of the plant group (WOESE et al., 1995, 1997; Kumpulainen, 2001; Mølgaard, 2000; Williams, 2002). A decreased protein content was observed for organically produced grain as well as for carrots and cabbage. According to ANDERSON et al. (2001) protein contents in organically cultivated grain is decreased about $10-20 \%$ compared to conventionally produced grain.

With lower protein content there is normally an accompanying lower gluten content (BOLLING et al., 1986; Dlouhy, 1981; Granstedt \& KJellenBerg, 1996; SteineCK \& LiebHard, 1984). Table 1 shows a comparison of protein content of organically and conventionally produced grain.

Table 1: Crude protein content of organically and conventionally produced cereals (\% DM)

\begin{tabular}{|l|c|c|l|}
\hline \multicolumn{1}{|c|}{ Cereal } & conventional & organic & \multicolumn{1}{c|}{ Literature } \\
\hline Wheat & 12.8 & 12.8 & $\begin{array}{l}\text { MINISTERIUM FÜR ERNÄHRUNG, } \\
\text { LANDWIRTSCHAT UND UMWELT } \\
\text { BADEN-WÜRTTEM-BERG, 1977 }\end{array}$ \\
\hline Wheat & 14.2 & 13.2 & $\begin{array}{l}\text { MINISTERIUM FÜR ERNÄHRUNG, } \\
\text { LANDWIRTSCHAT UND UMWELT } \\
\text { BADEN-WÜRTTEM-BERG, 1977 }\end{array}$ \\
\hline Wheat & 15.4 & $12.6-13.6$ & PETTERSON, 1982 \\
\hline Wheat & 16.1 & 14.6 & DLOUHY, 1981 \\
\hline Wheat & 13.8 & $11.0-10.1$ & SCHELLER, 1999 \\
\hline Wheat & 11.9 & 10.6 & SHIER et al., 1984 \\
\hline Wheat & 11.7 & 11.2 & RAUPP et al, 1994 \\
\hline Wheat & 13.8 & 10.711 .2 & KIEFFER, 1995 \\
\hline Wheat flour & 10.8 & $8.8-9.2$ & HAGLUND, 1998 \\
\hline Barley & 11.1 & 11.2 & $\begin{array}{l}\text { MINISTERIUM FÜR ERNÄHRUNG, } \\
\text { LANDWIRTSCHAT UND UMWELT } \\
\text { BADEN-WÜRTTEM-BERG, 1977 }\end{array}$ \\
\hline Barley & 13.7 & 11.1 & PETTERSON, 1982 \\
\hline Barley & 14.1 & 11.9 & DLOUHY, 1981 \\
\hline Rye & $12.1-12.7$ & 12.3 & KLEIN, 1968 \\
\hline Oat & 13.1 & 10.7 & $\begin{array}{l}\text { MINISTERIUM FÜR ERNÄHRUNG, } \\
\text { LANDWIRTSCHAT UND UMWELT } \\
\text { BADEN-WÜRTTEM-BERG, 1977 }\end{array}$ \\
\hline Oat & $15.5-16.1$ & $14.8-15.3$ & KLEIN, 1968 \\
\hline
\end{tabular}

Considering that cultivar specific differences in plant ingredient composition together with the role played by locational and production-technical influences, the values found in the literature will, with few exceptions, only show a tendency. 


\section{Protein quality}

Elevated nitrogen fertilization or nitrogen availability does not only influence the protein content, but also the content of free amino acids and amino acid composition. This could result in an improved protein quality in organic products as confirmed in several studies (Brandt \& MølgaARD, 2001; Delgado et al., 1999; Dloughy, 1981; Williams, 2002; WOESE et al., 1995; WOLFSON \& SHEARER, 1981).

Dloughy (1981, 1983), Petterson (1982) and Gransted \& KJellenberg (1996) calculated in Swedish long-term trials the EAA-Index (essential amino acid index) as a mark for the biological value of proteins. This value was about $2.5-5.0 \%$ elevated in organically compared to conventionally produced wheat. In these trials the EAA index was negatively correlated with crude protein content. An assignment of amino acids to special protein fractions was carried out in only one case (SCHELLER, 1999). Accordingly, organically produced wheat cultivars, which seem to have lower protein content, showed the highest protein quality. The portion of globulins and albumins that contain higher contents of essential amino acids (threonine, cysteine, lysine, methionine and valine) was highest among organic wheat cultivars, which showed a more balanced distribution of amino acids.

\subsubsection{Carbohydrates}

According to BRANDT \& MøLgaARD (2001) the "C/N Balance Theory" decides which substance was predominantly synthesized by the plant. This means, if $\mathrm{N}$-availability is low, fewer nitrogen-rich substances but more carbohydrate-rich substances such as starch, NSP and non-nitrogen containing secondary plant ingredients will be synthesized.

As nitrogen availability is limited in organic farming with the resultant lower protein content than in conventional farming, there should be an increased production of starch, NSP and other carbohydrate rich substances.

\section{Starch}

Only few and mostly quite old literature sources which considered starch content of plant products in dependence of cultivation methods were found (table 2). Clear differences in the impact of the cultivation method are not documented. 
Table 2: Starch content of organically and conventionally produced cereals (\% DM)

\begin{tabular}{|l|c|c|l|}
\hline \multicolumn{1}{|c|}{ Cereal cultivar } & organic & conventional & \multicolumn{1}{|c|}{ Literature source } \\
\hline Wheat & 56.9 & 57.5 & KLETT (1968) \\
\hline Wheat flour & $69.2-70.9$ & 69.1 & HAGLUND et al., 1998 \\
\hline \multirow{2}{*}{ Rye } & $53.3-54.6$ & $52.8-53.4$ & KLEIN (1968) \\
& 526 & 53.1 & KLETT (1968) \\
\multirow{2}{*}{ Oat } & $53.0-54.4$ & $53.3-53.6$ & KLEIN (1968) \\
& 49.4 & 48.0 & KLETT (1968) \\
\hline
\end{tabular}

\section{Non-Starch Polysaccharides (NSP)}

According to the $\mathrm{C} / \mathrm{N}$ Balance Theory there should not only be an increased portion of starch in organic farming but also an increased portion of NSP (BRANDT \& MøLGAARD, 2001).

The only literature source concerning the dietary fiber (NSP + lignin) content gave NSP proportions of $11.9 \%$ for conventional and $11.4-12.3 \%$ of DM for organic produced wheat (HAGLUND et al., 1998).

\subsection{Physiological effects of fiber-rich organic feedstuff}

The last chapters have shown differences in plant composition of organically and conventionally cultivated plants. This, together with the requirement for daily availability of roughage in organic pig production, could lead to different composition of feed rations in organic pig diets compared to those used in conventional farming. Besides protein content and protein quality, especially the content of NSP in the diet is strongly influenced.

Even if there is only limited research considering the effect of organic diets, investigations carried out with elevated NSP-contents indicate clear changes in digestive physiological processes.

\subsubsection{Degradation of NSP}

\subsubsection{General}

On average, a pig diet contains 550-700g carbohydrates per kilogram dry matter. These carbohydrates consist of about 40-70g low molecular weight sugars, 250-400g starch and 150$250 \mathrm{~g}$ NSP (BAKKER et al., 1998). It is assumed that the amounts of NSP in organic diets are considerably higher due to the afore mentioned production terms and the demanded roughage addition (CARlson et al., 1999; DANIELSEN, 2000, 2001; HERMANSEN, 2000). 
NSP are polysaccharides, which are not classified as starch. The NSP fraction includes the fractions of crude fiber and a part of $\mathrm{N}$-free extract determined with the Weende feed analysis. According to their chemical composition and the accompanying solubility characteristics they can be separated in soluble and non-soluble NSP (JEROCH et al., 1999).

The insoluble fraction comprises cellulose and most of the hemicellulose. Hemicelluloses mostly consist of pentoses like xylose and arabinose, but can also be connected to the hexoses glucose, mannose, and galactose (BACH KNUDSEN, 1997; JEROCH et al., 1999). The soluble fraction contains pectin, hemicelluloses and oligosaccharides. ß-glucanes are very important representatives of this fraction.

\subsubsection{Degradation of NSP in the digestive tract}

NSP are not degradable by endogenous enzymes of pigs and reach the caecum and colon of the animals nearly undigested. Therefore these components, mostly consisting of cellulose, hemicelluloses and lignin, need to be fermented by microbes in the hindgut. Physiological effects of NSP are dependent on their physicochemical properties. Soluble NSP are viscous and can already be degraded to smaller molecular units in the small intestine, whereas insoluble, partly lignified NSP, are not viscous and slowly fermented along the colon (BACH KNUdSEN et al., 1991; BACH KNUDSEN \& CANiBE, 2000; Christensen et al., 1999; Govers et al, 1999; SHI \& NOBLET, 1993a, b).

Efficient fermentation of NSP in caecum and colon requires sufficient nitrogen for microbial growth. Furthermore the composition of NSP as the fermentable substrate and main energy source for microbes plays an important role (BACH KNUDSEN et al., 1993a, b; BAKKER et al., 1998; Christensen et al, 1999; Freire et al., 2000; KreuZer et al., 1999; Le GofF et al., 2002).

The sequence of carbohydrate degradation in the gastrointestinal tract of pigs was analyzed by means of ileum-canulated pigs and by analyzing the digesta of different sections of the digestive tract after pigs were slaughtered (BACH KNUDSEN et al., 1991, 1993a, b). Accordingly the order of carbohydrate-breakdown is as follows: starch, B-glucanes, arabinoxylanes and finally cellulose are degraded. Starch digestion could not be proved to take place in the stomach, but was observed to a greater extend in the small intestine. Digestibility of $\beta$-glucanes was low in the stomach and small intestine but high in the large intestine. The break down of arabinoxylanes and cellulose did not occur in the small intestine but in the caecum and colon (BACH KNUDSEN et al., 1991, 1993; BACH KNUDSEN \& CANIBE, 2000; Bach Knudsen \& Hansen, 1991; Canibe \& Bach Knudsen, 2001, Shi \& Noblet, 
1993a, b). Caecum and colon are the main parts of the digestive tract for carbohydrate fermentation. B-glucane and arabinoxylane degradation according in different sections of the digestive tract is shown in figure1.
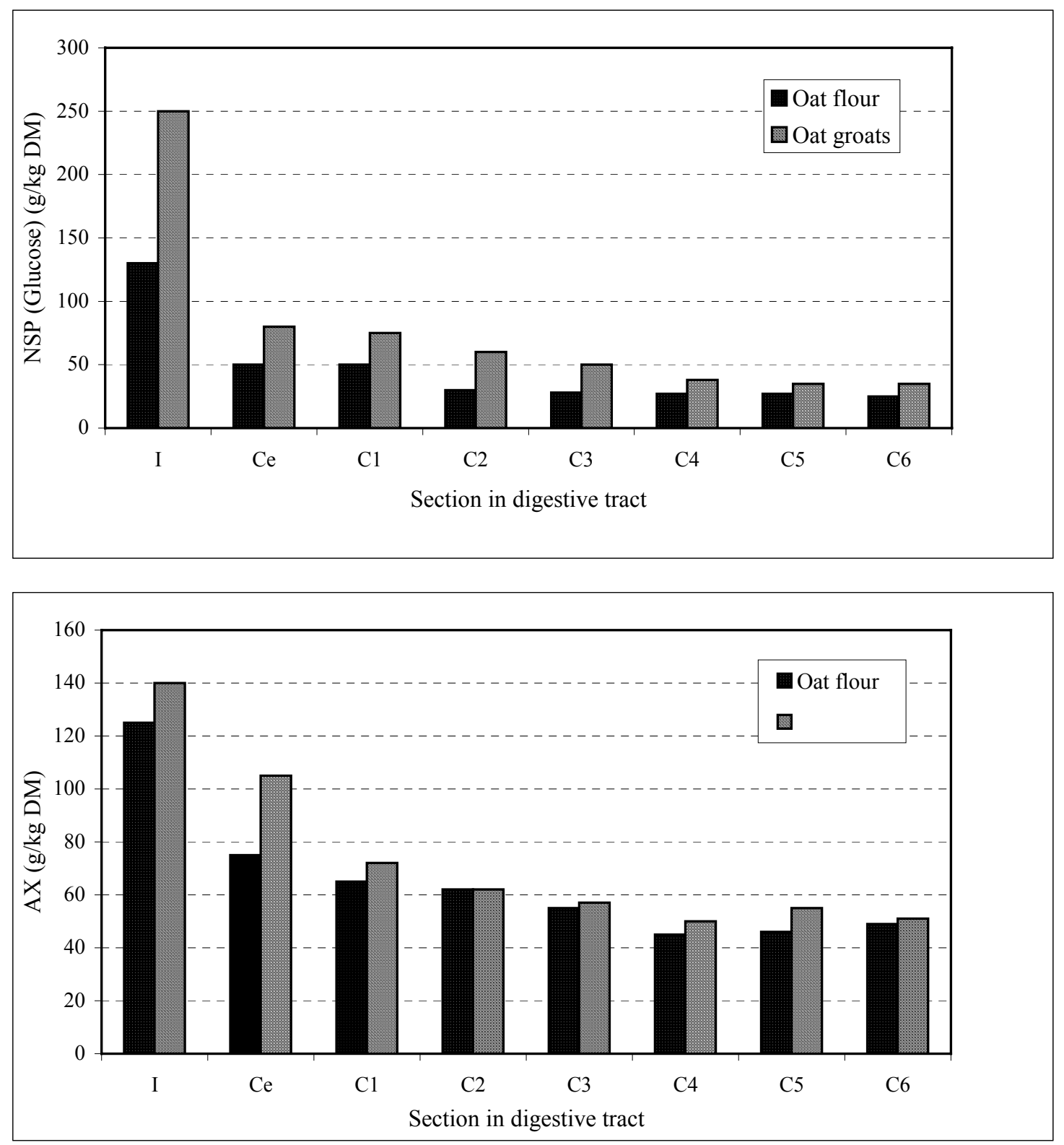

Figure 1: NSP (Glucose)- and Arabinoxylan-concentration ( $/ \mathrm{kg} \mathrm{DM})$ in different sections of the digestive tract of pigs according to BACH KNUDSEN (1993b), (I: Ileum; Ce: Caecum; C1: proximal Colon, C2 and C3: ascending Colon; C4 and C5: descending Colon; C6: distal Colon)

Other feeding experiments showed that, depending on the chosen main NSP component of the diet, there were clear differences in bioconversion as well as in the location of microbial fermentation (BACH KNUdSEN et al., 1991, 1993a, b; BACH KNUdSEN \& CANIBE, 2000; CAnibe \& Bach Knudsen, 2001; Freire et al., 2000; Govers et al., 1999; Graham et al., 1985; Millard \& CHESSON, 1984). 
Even different fractions of the same cereal species lead to differences in bioconversion of NSP (BACH KNUDSEN et al., 1993b). Clearer differences still were observed in feeding trials using different NSP sources. FREIRE et al. (2000) investigated the digestibility of NDF, ADF, hemicellulose and cellulose in dependence of diets based on wheat bran, sugar beet pulp, soybean hulls and alfalfa. They discovered that digestibility was highest when sugar beet pulp and lowest when wheat bran was fed. This fact was attributed to differing amounts of cell wall components and their partial lignification (BACH KNUDSEN et al, 1991; 1993; BACH KNUDSEN, 1997; CHABEAUTI et al., 1991, NoBlet \& BouRdON, 1997).

But also particle size and retention time seem to be important for NSP degradation (BACH KNUDSEN et al., 1991, 1993a, b; HoEBLER et al., 1998; JøRGENSEN et al., 1996).

Table 3: Digested polysaccharides (\%) in ileum and feces in dependence of the dietary oat fraction according to BACH KNUDSEN et al. (1993b)

\begin{tabular}{|l|c|c|c|c|}
\hline & Rolled oats & $\begin{array}{c}\text { Oat flour } \\
\text { (high starch content) }\end{array}$ & $\begin{array}{c}\text { Oat flour } \\
\text { (low starch content) }\end{array}$ & Oat bran \\
\hline Ileum & & & & 98.9 \\
\hline starch & 97.0 & 98.6 & 98.5 & 15.0 \\
NSP & 21.0 & 25.0 & 24.0 & 20.0 \\
-Glucose (total) & 31.0 & 32.0 & 30.0 & 17.0 \\
-ß-Glucan & 28.0 & 30.0 & 31.0 & 11.0 \\
-Arabinoxylan & 2.0 & 7.0 & 6.0 & 18.0 \\
insoluble NSP & 11.0 & 17.0 & 13.0 & 16.0 \\
soluble NSP & 31.0 & 36.0 & 36.0 & 100.0 \\
\hline Feces & & & & 90.0 \\
\hline starch & 100.0 & 100.0 & 100.0 & 94.0 \\
NSP & 88.0 & 87.0 & 87.0 & 100.0 \\
-Glucose (total) & 92.0 & 92.0 & 93.0 & 83.0 \\
-ß3-Glucan & 100.0 & 100.0 & 100.0 & 79.0 \\
-Arabinoxylan & 82.0 & 82.0 & 82.0 & 98.0 \\
insoluble NSP & 77.0 & 76.0 & 76.0 & 96.0 \\
soluble NSP & 96.0 & 96.0 & & \\
\hline
\end{tabular}

\subsubsection{Microbial growth and microbial activity}

NSP are fermented by intestine microbes in the digestive tract of pigs with the amount of microbes being influenced by the segment and by the diet. BACH KNUDSEN et al. (1993a) determined $0.9-1.5 \times 10^{9}$ viable bacteria per gram digesta in the distal part of the small intestine, which increased to $1.2-1.6 \times 10^{9}$ viable counts in the caecum. While feeding a high fiber diet resulted in significant differences in the number of viable bacteria in the stomach (JENSEN \& JøRGENSEN, 1994) there was only a trend for higher microbe numbers in the small intestine, caecum and proximal part of the colon. The bacterial composition was not influenced by feed ingredients. 
KREUZER et al. (1999) who investigated the affect of diets containing high BFS contents on the amount of fecal bacterial $\mathrm{N}$ excretion could not prove a clear tendency for elevated bacterial N-excretion with increased BFS contents.

ATP as well as AEC (Adenylate Energy Charge) determinations as indicators for microbial activity showed a dependence of section and feed composition. Highest ATP concentrations could be determined in the caecum, while concentration decreased to the end of the colon caused by the reduction of fermentable substrate (BACH KNUDSEN et al., 1993b; JENSEN \& JøRGENSEN, 1994). Clear differences were observed when examining the affect of feed composition on ATP concentration. While feeding an easily digestible or a $\beta$-glucan rich diet ATP concentration were $33 \mathrm{nmol} / \mathrm{g}$ digesta in caecum content and $33 \mathrm{nmol}$ in the proximal colon but decreased to $9-14 \mathrm{nmol}$ in the distal colon. Values were significantly elevated when diets containing high contents of insoluble fiber fractions were fed. Values in the caecum were about $62-66 \mathrm{nmol} / \mathrm{g}$ digesta and decreased to $50-58 \mathrm{nmol}$ in the proximal colon and 11$13 \mathrm{nmol}$ in the distal colon.

\subsubsection{SCFA production in the digestive tract}

Not degraded or non-degradable carbohydrates are fermented by intestine microbes during their passage through the intestinal tract and converted to short chain fatty acids (SCFA). Therefore it is possible to draw conclusions on the extension of NSP fermentation by means of the SCFA amount. Main fatty acids in the digestive tract are acetate, propionate and butyrate. Lactate occurs only in small amounts.

The different carbohydrates being offered with the diet strongly influence fatty acid production rate and composition (BACH KNUDSEN et al, 1993a, b; BACH KNUDSEN \& CANIBE, 2000; Bingham, 1990; Bolduan et al., 1991; CAnibe \& BaCH Knudsen, 2001; CHRISTENSEN et al, 1999; FrEIRE et al, 2000; JøRGENSEN et al, 1996).

BACH KNUDSEN et al. (1993a) investigated the influence of different dietary fiber contents on the amount of produced SCFA using diets containing wheat flour, B-glucan enriched wheat flour, with insoluble NSP enriched wheat flour and oat bran. They observed a dietary effect for caecum and colon. If NSP poor diet was fed, SCFA concentration in caecum and colon was about $88-95 \mathrm{mmol} / 1$ digesta and increased significantly with feeding NSP enriched diet, reaching values of $127 \mathrm{mmol} / 1$ in the caecum and $101-151 \mathrm{mmol} / 1$ in the proximal colon. Independent of the diet there was a clear decline of SCFA produced in the descending colon. In contrast to the study described above, which only showed slight differences in SCFA production between diets containing soluble and insoluble NSP, BACH KNUDSEN \& CANIBE 
(2000) described, that the amount of SCFA was cut in half if fiber rich oat bran diet with higher contents of soluble NSP was fed instead of fiber rich wheat bran diet containing high portions of insoluble NSP. BOLDUAN et al. (1991) observed an increase in total SCFA production of $100 \mathrm{mmol} / 100 \mathrm{~g} \mathrm{DM}$ when feeding fiber rich grass meal diets and of $259 \mathrm{mmol} / 100 \mathrm{~g}$ DM when feeding pectin rich sugar beet pulp diet.

Blood analyses of pigs showed that the amount of NSP does not only influence the amount of produced fatty acids in the digestive tract but also the amount of absorbed fatty acids in the intestine (BACH KNUDSEN et al., 2000).

BOLDUAN et al. (1991) investigated the fatty acid composition depending on the NSP fraction being used in the diet. They observed an increase in acetate production in the caecum and proximal colon when fiber rich grass meal diet (insoluble NSP) as well as pectin rich diet was fed. Acetate production was higher in the caecum when feeding sugar beet pulp, but higher in the colon when feeding grass meal diet. Propionate production was increased in a starch rich control diet compared to the other diets. Butyrate did not show a diet depending effect in the caecum and proximal colon but seems to be significantly influenced in the distal colon. FREIRE et al. (2000) also observed varying amounts and proportions of every individual fatty acid on total fatty acid content in the large intestine content. Their results are shown in table 4.

Table 4: Concentration of different fatty acids in the intestine content of pigs ( $\mathrm{mg} / \mathrm{g}$ gut content) in dependence of NSP source according to FREIRE et al. (2000; modified)

\begin{tabular}{|l|c|c|c|c|}
\hline & Wheat bran & Sugar beet pulp & Soy bean hulls & Alfalfa \\
\hline Acetate & 2.36 & 2.11 & 3.03 & 2.19 \\
Propionate & 1.35 & 1.09 & 1.38 & 1.28 \\
Butyrate & 0.74 & 0.60 & 0.56 & 0.43 \\
Total & 4.46 & 3.80 & 4.96 & 3.90 \\
\hline
\end{tabular}

Christensen et al. (1999) observed the influence of NSP type on the amount and composition of synthesized fatty acids with ileum-cannulated pigs and by using in vitrofermentation. As expected they found the lowest SCFA production for low fiber diet. Significant differences concerning fatty acid amount were observed between high fiber oat bran diet ( $850 \mathrm{mmol}$ fatty acid per $\mathrm{kg}$ feed) and wheat bran diet (560mmol per kg feed). Fiber rich wheat bran diet resulted in the highest portion of acetate, while propionate portion was highest in low fiber diet and butyrate proportion highest for the oat bran diet.

BACH KNUDSEN et al. (1991) and BACH KNUDSEN \& CANIBE (2000) also found highest proportion of butyrate on total SCFA production when an oat bran diet was fed. No clear diet dependent differences were found for acetate and propionate. 
Blood analyses, determining the absorption of nutrients originating from carbohydrate degradation confirmed a higher butyrate rate in the portal vein after feeding oat bran compared to feeding wheat bran, which was mostly due to the increased butyrate production with fermenting soluble NSP. Total SCFA content increased when feeding fiber rich diets, whereas the blood lactate content significantly decreased (BACH KNUDSEN et al., 2000).

\subsubsection{Influence of NSP on energy metabolism}

Fiber rich diets show low energy density caused by their low digestibility and their low net energy value (EGGUM et al., 1982; JøRGENSEN et al., 1996; SHI \& NOBLET, 1993 a, b).

Fermentation of fiber rich substances during their passage through the digestive tract and the resultant conversion to SCFA is the only possibility for gaining energy from these substances, with SCFA having principally lower biochemical efficiency compared to other carbohydrates (RÉMÉSY et al., 1992; SHI \& NOBLET 1993a, b). Thus, the yield of metabolizable energy from acetate is only $84 \%$ and from butyrate $87 \%$ of the amount from glucose. In spite of that the fermentation of dietary fiber has possible effect on the total energy balance of the animals.

JøRGENSEN et al. (1997) were able to prove during investigations on the energetic values of SCFA, that net efficiency (retained energy/gross energy) was $82 \%$ of which fat retention was $72 \%$. Only a small portion was retained as protein. They also found that utilization of digested $\mathrm{N}$ increased when SCFA were infused in the digestive tract. The increase of $\mathrm{N}$ retention under the influence of SCFA was explained with the fact that SCFA can be used as an extra energy source for protein synthesis when pigs are fed below energy requirement level.

The difference in energy utilization between carbohydrates being absorbed as monosaccharides and SCFA is due to the formation of fermentation gases $\mathrm{H}_{2}, \mathrm{CH}_{4}$ and $\mathrm{CO}_{2}$ as well as to the heat production caused by fermentation processes in the digestive tract (JørGENSEN et al., 1997; LE GOFF et al., 2002). Thus, it can be concluded that feeding fiberrich diets results in increased energy losses compared to easy digestible starch or fat rich diets.

The influence of fiber-rich diets on energy balance in growing pigs and adult sows was investigated in several studies (CHRISTENSEN et al., 1999; FREIRE et al., 2000; JøRGENSEN et al, 1996; KreUZER et al, 1999; Le Goff et al., 2002; Noblet \& LE GofF, 2001, RAMONET et al., 2000; RiJINEN et al., 2001; SCHRAMA et al., 1996. However results are not always unambiguous. 


\section{Heat production}

LE GofF et al. (2002) investigated the influence of fiber-rich feedstuff of different origin on total heat production as well as on its components: fasting heat production, activity heat production and thermic effect of feeding. The latter was divided in a short-term component and a long-term component. The short-term component considers the heat production originating from feed intake, digestion and absorption, while the long-term component includes the emerging energy from long-term metabolic processes such as fermentation.

In experiments carried out by RIJINEN et al. (2001) dietary fiber content did not influence total heat production, which is in contradiction to experiments carried out by JøRGENSEN (1996), RAMONET et al. (2000) and SCHRAMA et al. (1996) indicating increased heat production with increased dietary fiber content. An effect of botanic origin of fiber on total heat production was not determined (LE GOFF et al., 2002; JøRGENSEN et al., 2001).

The thermic effect of feeding was clearly influenced by the fiber content (LE GoFF et al. 2002, RAMONET et al., 2000) and differences were mostly due to differences in the long-term effect of feeding, showing highest values for fiber-rich diets.

\section{Energy losses by fermentation gases}

Besides energy losses caused by heat production there is further energy loss caused by the production of fermentation gases. While methane mostly arises in the caecum and colon of pigs, hydrogen mainly occurs in the small intestine (JENSEN \& JøRGENSEN, 1994).

In an experiment concerning methane losses JøRGENSEN et al. (1996) found significant differences in the amount of energy loss between diets containing low and those with high dietary fiber contents. While energy loss in a low dietary fiber diet was only $0.2 \%$ of the digestible energy, it raised to 1.1-1.3\% when fiber-rich diets were fed. JENSEN \& JøRGENSEN (1994) found a methane production of 1.41 per day when feeding NSP poor diets, while the amount of produced methane increased to 12.51 with the use of NSP rich diets.

LE GoFF et al. (2002) found out, that methane loss is linearly related to dietary fiber intake, with a $1.4 \mathrm{~kJ}$ increase for every gram digested dietary fiber. Values recorded by RAMONET et al. (2000) and JøRGENSEN et al. (2001) were in accordance with the mentioned results. Energy losses by methane observed by RIJINEN showed slower increase in methane production with increasing dietary fiber. Under the assumption that one gram dietary fiber has an energy content of 18,1kJ Le GofF \& Noblet (2001), Le Goff et al. (2002), Noblet \& Le GofF (2001) and RIJINEN et al. (2001) concluded an energy loss by methane of 3-7\% per gram of digestible dietary fiber. 
Methane in fact is not the only loss-source. JENSEN \& JøRGENSEN (1994) observed during investigation about in vitro fermentation $\mathrm{H}_{2}$-production rates which correspond to $40 \%$ of methane production. They also found differences in $\mathrm{CO}_{2}$ production rates between diets containing low and high fiber contents, especially for $\mathrm{CO}_{2}$ production in stomach and colon. While $\mathrm{CO}_{2}$ production in the stomach with feeding high fiber diet was $43-47 \%$ of total gas production, it decreased to $16-18 \%$ with feeding low fiber diet and was also lower in the colon compared to feeding fiber-rich diets. Complementary in vitro fermentation confirmed significantly higher production rates connected with increased microbial activity when feeding fiber-rich diets.

\subsubsection{Influence of NSP on the digestion and absorption of other nutrients}

In order to achieve maximum benefit for the animals, dietary nutrients like starch, sugar, fat, protein and minerals need optimal digestion and absorption. However, several studies showed that the use of NSP-rich feed stuff or NSP additives impair those digestive processes.

\subsubsection{Influence of NSP on passage rate during the gastrointestinal tract}

The retention time of digesta during the passage through the gastrointestinal tract under the presence of NSP is an important factor for digestion and absorption of nutrients. It is widely assumed that retention time is reduced when NSP are present. However, it could be proved that increasing fiber content led to reduced retention time only in the colon, while passage time in the precaecal digestive tract was not influenced or even prolonged (BAKKER et al., 1998; JOHANSEN et al., 1996; Low, 1990; MiQuEL et el., 2001).

Clear differences were observed between different NSP fractions. They show that soluble NSP lead to a prolonged passage rate in the preceacal digestive tract, while insoluble NSP mostly showed no or only slight influence (Low, 1990).

PotKINS et al. (1991) investigated the influence of botanic origin of the NSP by substituting barley flour for bran, by-products from oat flour production, guar gum or pectin. They found that passage rate increased by increasing the amount of bran and thereby increasing the NSP content. In contrast to studies mentioned in the following text, the use of pectin and guar gum with high soluble NSP content accelerated gastric emptying.

JoHANSEN \& BACH KNUDSEN (1994), JoHANSEN et al. (1996) and MiQuel et al. (2001) also proved the influence of different NSP sources (wheat flour, wheat bran, oat flour, oat bran and sugar beet pulp) on gastric emptying in pigs. It was shown that there are clear differences in 
the influence of different NSP sources on liquid and solid digesta-phase). Diets containing higher amounts of soluble NSP and an elevated portion on total NSP resulted in a reduced rate of gastric emptying. Viscosity-elevating properties of NSP in the digestive tract are considered to be the main reason for delayed gastric emptying. In particular, soluble NSP in the form of $\beta$-glucanes showed viscosity-elevating affects due to an increased stimulation of digestive juices secretion, which was also observed for insoluble NSP, and their enormous water-binding capacity (JOHANSEN et al., 1996; MiQUEL et al., 2001).

The higher viscosity with feeding diets containing high soluble NSP content was detected even after a period of several hours after feeding. As expected, the highest differences were observed within the first 5 hours after feeding. Not only type and origin of NSP seem to play a role concerning digesta viscosity, but also structure and particle size (JOHANSEN \& BACH KNUDSEN, 1994; JOHANSEN et al., 1996; Low, 1990; PotKINS et al., 1991; WISKER \& FELDHEIM, 1992).

While most experiments examine the influence of NSP on gastric emptying, there are only a few, which consider physiological effects in the small intestine.

JOHANSEN \& BACH KNUDSEN (1994) determined the effect of NSP on passage rate in the small intestine by means of fitting pigs with re-entrant cannulas in the jejunum. The aim was to study the digesta flow in the upper intestine with diets varying in their soluble fiber content. This was achieved through diets containing oat flour, rolled oats and oat bran. As expected, the diet containing highest fiber contents resulted in the highest amount of digesta and the highest water-binding capacity. Furthermore, the flow of digesta within the first hour after feeding was lower for wheat flour, rolled oats and oat bran compared to oat flour. There were also differences in the flow of dry matter, starch, xylose, total NSP and the liquid digesta phase.

Different amounts and types of fiber also influenced the retention time in the large intestine of pigs (KESTLING et al., 1991). Diets containing high fiber content showed the shortest passage rate. Studies with humans confirm these results (READ \& EASTWOOD, 1992).

JøRGENSEN et al. (1996) observed a simultaneous increase in caecum and colon length, which compensates for the effect of passage time and thereby assures high nutrient utilization when a high fiber diet was fed. Morpho-physiological adaptations on fiber rich diets were also observed by ZHAO et al. (1995) and DERSJANT et al. (2001).

Besides changed retention times in the digestive tract, the intestine motility inhibiting effects of soluble NSP play an important rule (EDWARDS, 1990; FLOURIÉ, 1992; FURDA, 1990). The formation of a water layer between digesta and mucosa and decreased motility lead to a 
reduced contact between digestible substrate and the specific enzymes and might cause problems involving nutrient absorption due to a reduced contact between resorbable substrates and mucosa.

\subsubsection{Influence of NSP on digestion of starch and sugar}

Main part of the digestive tract for digesting starch and sugar is the small intestine. There have been several studies regarding the effect of NSP on digestion of starch and sugar. In general they found none (BACH KNUDSEN et al., 1993a; BACH KNUDSEN et al., 2000; DROCHNER, 1984; RAMONET et al., 2000) or only temporary changes in digestion and absorption (GALIBOIS et al., 1994). Only JØRGENSEN et al. (1996) were able to prove a decrease in starch digestion to $95 \%$ digested starch in the small intestine when fed on a high fiber diet (pea fiber, pectin and barley) in contrast to complete digestion with feeding a low fiber diet. However, there was no starch left at the end of the colon when feeding a fiber rich diet.

FLOURIÉ (1992) observed in studies with humans and MICHEL \& RÉRAT (1998) in studies with pigs a decelerated glucose resorption in the small intestine, whereas the total amount of resorbed glucose was not affected by fiber rich nutrition. The above-mentioned decelerated gastric emptying, which influenced the amounts of carbohydrates available in the small intestine is considered to be the main reason for delayed glucose absorption. Furthermore, there are indications for an impairment of pancreas amylase activity by different effects of NSP. This could result from a change in the $\mathrm{pH}$ value, ion exchange capacity, enzyme inhibitors as well as a decreased secretion of amylase. Viscosity elevating properties may lead to a reduced enzyme substrate contact (CAMERON, 2000; FlOURIÉ, 1992; MiCHEL \& RÉRAT, 1998; MOSENTHIN \& SAUER, 1993).

\subsubsection{Influence of NSP on protein digestion}

The amount and the quality of proteins being available with the feed are very important for optimal growth and capability of animals. Therefore, the knowledge of the influence of NSPrich diets on the digestibility of food proteins is very important. Several studies involving this theme found a clearly reduced apparent protein digestion in the entire digestive tract, which was caused by indirect as well as direct processes (BOISEN \& FERNÁNDEZ, 1995; DE LANGE et al., 1990; EGGUM, 1992). 
Endogenous nitrogen losses are originated by an increased secretion as well as by intensified cell desquamation when feeding high fiber diets. Furthermore, increasing dietary fiber content reduces the digestion of dietary and endogenous protein.

Also, the presence of an active microflora in the large intestine under the influence of NSP rich feeding leads to a reduced absorption of protein and amino acids and an increased portion of microbial nitrogen in the feces.

BOISEN \& FERNÁNDEZ (1995) investigated the apparent digestibility of proteins and amino acids by means of different feedstuff in vitro. They achieved higher digestibility values for nearly all the various kinds of feedstuff with the in vitro investigations compared to values achieved for the same feedstuff in vivo. The differences were due to the endogenous protein loss. It was shown that endogenous loss is dependant on the chemical composition of the feed and besides there did exist a positive correlation between undigested dry matter, which is higher with NSP-rich feeding, and endogenous protein loss.

Different digestibilities for single amino acids are caused by different reasons. Besides enzyme specification in the case of arginine and methionine, the accessibility of the enzymes to the different protein fractions as in the case of lysine in cereals, the antinutritive properties of NSP in the case of cysteine in leguminous plants, endogenous losses play an important role. This fact was usually found for the amino acids threonine and proline and depends primarily on mucin losses in the large intestine.

DE LANGE et al. (1990) analyzed the endogenous nitrogen losses by means of ${ }^{15} \mathrm{~N}$-isotopes and thereby were able to determine the true protein- and amino acid digestion for diets containing different types and amounts of dietary fiber. They observed clear differences in the apparent and true digestibility depending on the origin and the amount of dietary fiber. Values given for the amount of endogenous amino acids varied between 13.7-24.7\% per 100g crude protein intake, depending on the diet.

LETERME et al. (2000) found clear differences in apparent protein digestibility and endogenous nitrogen losses during experiments with different barley types, which differed in their total NSP and in soluble NSP content. Apparent digestibility was 65.9-73.4\%, true digestibility $77.8-82.1 \%$. Significant differences were only proved for apparent digestibility, with highest digestibility for a diet containing lowest fiber content. This variant also showed the lowest endogenous nitrogen losses.

As a result of an increased number of microbes as well as an increased microbial activity in the intestine tract with feeding NSP rich diets, protein absorption can be clearly reduced. MiCHEL \& RÉRAT (1998) determined by means of blood analyses a slight decrease in 
absorbed nitrogen with fiber-rich feeding. A difference between the fiber been used for the experiment (wheat bran or sugar beet pulp) was not observed.

KREUZER et al. (1991) were able to prove that the infusion of fermentable substrate in the caecum lead to an increased portion of protein being excreted with feces in dependence of the fermentability of the respective substances. The amount of nitrogen bound in bacterial protein is also dependent on the respective substance. Its portion was $10.8 \%$ in the control group without infusion, $14.7 \%$ with cellulose infusion, $15.9 \%$ with starch infusion and $16.2 \%$ and $16.9 \%$ for pectin and xylose-infusion respectively. LE GOFF \& NOBLET (2001), MrOz et al. (2000) and ZERVAS \& ZIJLSTRA (2002) also observed a significant increase in fecal Nexcretion with increasing dietary fiber content, while $\mathrm{N}$ losses via urine and gases were not influenced or even reduced.

Some investigations (BAKKER et al., 1996; BEAMES \& EGGUM, 1981; BERGNER \& TegtMeier, 1985; Mosenthin et al., 1992a, b) were able to prove that nitrogen required for synthesis of protein in the intestine of pigs was secreted from the blood into the large intestine. Urea secretion from the blood increased with increasing microbial activity, which actually is the case when feeding fiber rich diets. Furthermore, a certain portion of the $\mathrm{N}$ used for microbial protein synthesis originated from ammonia, which is the main fermentation product of nitrogen-containing material in the intestine tract and could be used for the de novo-synthesis of bacterial protein (MOSENTHIN et al., 1992a, b; MOSENTHIN \& SAUER, 1993).

Besides an increased fecal excretion of endogenous $\mathrm{N}$ there is also an increasing excretion of proteins and amino acids supplied with the feed. GRALA et al. (1999) observed a lower digestibility of fiber rich feedstuff, which was caused by a high amount of structured glycoproteins (arabinogalactan and hydroxyprolin-rich glycoproteins). These glycoproteins are able to form complexes with each other or with cellulose-microfibrils and which consequently prohibit enzyme-substrate contact. Besides the binding of enzyme accessible protein on fiber components and because of that prevention of absorption leads to increased excretion of proteins supplied with the food. An impairment of enzyme activity in the case of trypsin and chymotrypsin was not observed (MOSENTHIN \& SAUER, 1993).

\subsubsection{Influence of NSP on fat digestion}

Its properties as an energy source make fat a popular component of energy poor diets, as common with the use of NSP-rich feedstuff, but it was shown that apparent and true digestibility in the total digestive tract was the more reduced, the higher NSP content in the 
feed was (BAKKer et al., 1998; Drochner, 1984, SHI \& Noblet, 1993 a, b). This could cause problems especially when feeding diets with lower energy content such as may be present in organic farming.

SCHRAMA et al. (1998), who were substituting starch-rich tapioca for NSP rich sugar beet pulp attained changes in the digestibility from $64 \%$ with 5\% SBP content to $60 \%$ with $15 \%$ SBP in the diet. BAKKER et al. (1998) observed while adding fat to diets containing differing levels of NSP (maize starch, cellulose, soy-bean hulls) a decrease in small intestine fat digestibility of about $4-7 \%$ and a decrease of total tract fat digestibility of $1-7 \%$ was realized. It was shown that, besides the amount of NSP, the type does have a crucial influence with a cellulose diet having the lowest fat digestibility.

BACH KNUDSEN et al. (1991, 1993a) also were able to prove the influence of amount and origin of NSP on apparent fat digestibility. They examined the ileal and fecal fat digestibility by means of diets based on oat groat, oat flour (NSP-poor), oat flour (NSP-rich) and oat bran. As expected, the NSP-poor oat flour diet showed highest and oat bran diet lowest digestibility. Different digestibility values were explained not only by different NSP contents in the diet, but also by the different origin inside the grain. Accordingly the reduced fat digestion, just as for protein digestion, is a result of substituting the endosperm cell wall material in oat flour by aleuron- and subaleuron cell wall material in bran, thereby acting as a barrier. Significant effects of structure and amount of NSP on digestibility of fat were also proved by GALIBOIS et al. (1994).

Reduced fat digestion under the presence of NSP, as proved in studies mentioned above, is caused by several mechanisms. First there is an increased portion of fatty acids in the digestive tract caused by increased secretion of bile acids in the small intestine (endogenous fat) and, second, there is an increased production of SCFA by microbes in caecum and colon (microbial fat) with an increased intake of NSP. Furthermore, fat digestion is influenced by a decrease in lipase secretion and lipase activity or a reduced digestion of fat being supplied with the feed, caused by influences of NSP on bile acids and micellar components due to changes in microbial metabolism (FURDA, 1990; JOHNSON, 1992; MADAR \& ODES, 1990; Mosenthin \& SAUER, 1993; SCHNEEMAN, 1990; StORY et al., 1990).

Physiological processes being responsible for reduced digestibility were further investigated especially in human medicine. Results show that digestion of fat as well as the resorption of monoglycerides and fatty acids is impaired under the presence of NSP. Fat digestion normally occurs by additional activity of pancreas lipase and bile acids. It could be showed that both, lipase activity and availability of bile acids were reduced depending on the amount and type 
of NSP (ANDERSON \& Siesel, 1990; Furda, 1990; GALIBOIS et al., 1994; Johnson, 1992, STORY, 1990).

Since fat is not water soluble, the presence of bile acids is necessary to achieve an emulsion. Only then can enzymatic digestion take place. Studies have shown that NSP are able to bind bile acids either chemically by ion bindings or physically. The so bound bile acids remain without any physiological effect, thus they cannot be resorbed and are therefore excreted with the feces. This results in an interruption of the enterohepatic bile acid cycle and leads to the consequence that more bile acids are formed in order to offset the loss. The newly formed bile acids differ in their composition depending on the fiber source and form. Combination products of bile acids and monoglycerides or fatty acids, the micells are also influenced by type and amount of NSP. As micells are imperative for transport of monoglycerides and fatty acids to the intestine mucosa, impairment in their functional ability leads to a reduced absorption of fat components. Absorption can be further reduced by formation of a water layer between mucosa and digesta (ANDERSON \& SiESEL, 1990; BEHALL, 1990; DEMEYER, 1995; FurdA, 1990; GALIBOIS et al., 1994; JOHNSON, 1992; MAdAR \& Odes, 1990; NAGENGAST, 1992; StORY et al., 1990).

\subsubsection{Influence of NSP on mineral absorption}

Minerals are very important ingredients of diets as they have different functions in the body and are essential for maintaining metabolism. In vitro investigations have shown that fiber and fiber-associated substances have strong mineral binding and complex-forming abilities (FrøLICH, 1990; RossANDER et al., 1992), which can result in a lower mineral absorption. Furthermore, changes in $\mathrm{pH}$ values caused by NSP seem to play an important role, particularly for soluble NSP (CAMERON et al., 2000; FRØLICH, 1990). Specific characteristics of mineral metabolism make it difficult to measure the effect of NSP in vivo.

Minerals from the food are only absorbed in relatively small amounts and endogenous mineral secretion in the small intestine is quite high (DROCHNER, 1984; ROSSANDER et al., 1992). Consequently, intestinal and fecal mineral contents are mixtures of unabsorbed dietary minerals and unabsorbed minerals originating from endogenous secretion. Analyses with humans have shown, that low absorption rates together with relatively long transit times through the colon (30 days for zinc) making conventional balance experiments nearly impossible. For this reason it is very difficult to find relevant literature about minerals in animal nutrition. The few literature sources concerning long-term studies with isotopes having been made in the human medicine sector give no indication for a changed mineral absorption 
when NSP are added to the food. Only fiber associated substances as phytin phosphate were able to decrease mineral-absorption in the case of iron and zinc (ROSSANDER et al., 1992).

Studies with animals however showed clear changes of mineral metabolism when feeding NSP rich diets compared to diets containing low NSP contents. All studies, though, were short-term trials and due to the above-mentioned problems might not be meaningful.

The effects of NSP addition on mineral metabolism in comparison to normal feeding are dependent on the type and amount of added NSP (BAKKER et al., 1998; JONGBLOED \& MrOZ, 1997). DROCHNER (1984) determined a reduction of apparent digestibility of calcium, magnesium, phosphorous and potassium when a supplement of lignin-rich or crude fiber-rich wood cellulose, pure cellulose or pectin was added to an easily digestible diet. Concerning calcium and magnesium, already when feeding an easy digestible basal diet, there were higher concentrations of these minerals observed at the terminal ileum, than there should have been on the basis of the diet alone. This increase in mineral concentration, the source of which was endogenous secretions, was even increased to the doubled or tripled amount with fiber rich feeding. The largest portion of secreted minerals was resorbed till the end of the large intestine. However, with the addition of cellulose the amount of preceacal secretions of minerals were too high to be offset by post-ileal resorption. BAKKER et al. (1998) observed an $8 \%$ reduction in crude ash apparent digestibility when feeding NSP rich cellulose- or soybean hulls. This was mostly due to a $6 \%$ reduced calcium and phosphorous resorption and an about $8-14 \%$ reduced potassium absorption. In contrast, magnesium absorption was $9 \%$ increased while sodium absorption was not influenced when a cellulose diet was fed. GALIBOIS et al. (1994) were able to prove that a NSP source caused reduced absorption of the elements iron, zinc and magnesium at a higher level when cellulose or pectin diet was fed as compared to bran-diets containing both, soluble and insoluble NSP. The strong influence of fiber type was also confirmed by in-vitro studies carried out by KROYER et al. (1995), who observed a decrease of bioavailability of $98 \%$ for these minerals depending on fiber type.

As already described, the energetic use of NSP takes place by fermentation of these substances in the large intestine where SCFA are produced by microbial processes. Different experiments using the Ussing chamber have shown, that elevated SCFA concentrations in the large intestine can improve absorption of sodium (ZAHARIA et al., 2001) as well as of calcium (MINEO et al., 2001). This fact was explained by functions of SCFA in the paracellular transport system. 


\title{
3. Studies
}

\section{Study 1}

\section{Nutritional properties of organically and conventionally grown cultivars of wheat, barley and faba beans}

\begin{abstract}
A total of 56 samples representing 14, 4 and 6 different cultivars of wheat, faba beans and barley, each of conventional and organic cultivation were analyzed on their nutrient composition. Protein, starch, NDF and ADF content were analyzed in all plant types. Additionally glycoside content was determined in faba beans and pentosane content was determined in wheat. Protein content $(\% \mathrm{DM})$ was lower in organically compared to conventionally produced wheat (10.09 to 12.62), beans (27.35 to 29.31) and barley (11.68 to 13.26). Starch content was increased in organic wheat (58.95 to $61.84 \%)$ and barley (49.79 to $52.38 \%$ ) and decreased in organic faba beans (46.00 to $42.16 \%$ ). NDF content increased for all three species with organic farming, ADF increased for wheat and barley and decreased for faba beans. Pentosan content of wheat and glycoside content of faba beans were not significantly influenced by the cultivation method.
\end{abstract}

\section{Introduction}

Organically produced feedstuffs are products being cultivated under controlled production conditions regulated by the EC-Regulation on organic farming (Regulation (EWG) 2092/91) and its supplementary ordinances as well as by different national organic farming associations being organized in the International Federation of Organic Movements (IFOAM).

Because of the guidelines of the different organic associations, production terms of organic farming are different from those usually employed in conventional farming. Soil fertility should only be achieved by humus management and crop rotation. Only in special cases is farm own organic manure allowed to be mixed with other manures or commercial organic or mineral fertilizers. The use of easily soluble mineral fertilizers is forbidden. Plant disease control is achieved by adapted crop rotation and fertilization, thus promoting the plant's own defense mechanism as well as by the use of special breeds. The use of synthetic pesticides, growth regulators and herbicides is not allowed. (BUNDESMINISTERIUM FÜR 
VERBRAUCHERSCHUTZ, ERNÄHRUNG UND LANDWIRTSCHAFT, 2004; BIOLAND, 2001; DEMETER, 2002; NATURLAND, 2002).

It is supposed, that lower nutrient availability and the alternative way of plant protection in organic farming lead to different ripening processes and thus to a different composition of nutrients and other plant ingredients of the plant in comparison to conventionally produced feedstuff (BRANDT \& MøLGAARD, 2001).

The aim of this experiment was to evaluate influences of the cultivation method on the contents of protein, starch and fiber, pentosanes and glycosides in different cereal and faba bean cultivars grown under organic and conventional conditions.

\section{Materials and methods}

\section{Samples}

For the comparison of the nutritive composition of organically and conventionally produced cereal and faba bean cultivars, it was very important to get a sufficient number of really comparable samples, i.e. same cultivars that were grown either conventionally or organically under comparable conditions of climate, soil and year.

Therefore, several boards of agriculture and agricultural research stations were specifically asked for exactly these kinds of samples. Samples of wheat, barley and faba beans used for the present study were provided by the Landwirtschaftskammer Schleswig- Holstein, the Landwirtschaftskammer Hannover, the Landesanstalt für Pflanzenbau Baden- Württemberg and the Sächsische Landesanstalt für Landwirtschaft. The samples originated from cultivar trials and were chosen in a way that the same cultivar of organic and conventional production was grown under the same conditions of soil, temperature and precipitation.

\section{Analyses}

Protein

Determination of N-content was carried out with the LECO "Nitrogen Determinator FP 228" according to the method of Dumas (SCHUSTER et al., 1991). Crude protein content was calculated from the measured $\mathrm{N}$ content $(\mathrm{N}$ x 6.25 and for wheat $\mathrm{N}$ x 5.7) in dry matter. 
Starch

Starch content in the diet was determined polar metrically according to the Verbandsmethode of VDLUFA, sugar content was determined according to the method of Luff- Schorl (NAUMANN\& BASSLER, 1976).

\section{NDF and ADF}

NDF and ADF were determined in an ANKOM Fiber Analyzer according to the method of GOERING\& VAN SOEST (1970).

Pentosans

Pentosan content was analyzed according to the method of THOMANN \& SCHREINEMANN (1980).

\section{Glycosides}

Glycoside determination is based on the following principle: the sample is extracted with phosphoric acid in order to get a protein free extract. The UV-spectrum of this extract is equal to the one observed for vicin in faba beans and therefore can be determined by means of a vicin standard. Since the ratio of vicin to convicin in faba beans is $2: 1$, total glycoside content is derived semi-quantitatively.

Beans were ground to $0.5 \mathrm{~mm}$ and dried at $60^{\circ} \mathrm{C}$. A sample of $10 \mathrm{~g}$ was homogenized with $100 \mathrm{ml}$ of $4 \%$ phosphoric acid. The solution was filtered through a Whatman Nr. 4 filter paper and exactly $1 \mathrm{ml}$ of the filtrate was used for dilution with $100 \mathrm{ml}$ water or $0.1 \mathrm{~N} \mathrm{HCl}$. The absorption was measured at $273 \mathrm{~nm}$ in a spectrophotometer.

\section{Statistics}

Data analyses were performed using the SPSS 10.0 program. Data were tested by using a onefactorial analysis of variance considering the cultivation method (organic or conventional) as factor. 


\section{Results}

\section{Protein content}

Organic farming led to a significantly $(\mathrm{p}<0.05)$ lower protein content in wheat and barley compared to conventional production (figure 1). Protein content in faba beans was also affected, but differences were not significant.

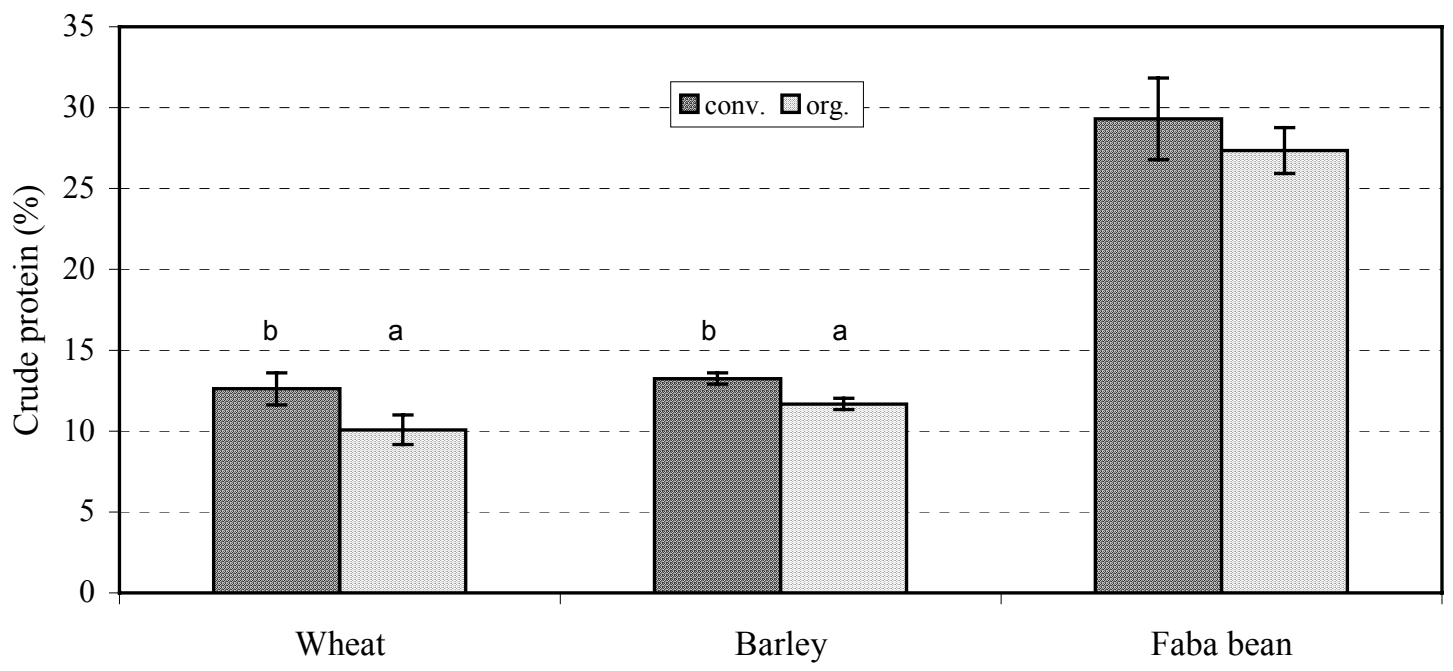

Figure 1: Influence of the cultivation method on crude protein content in wheat, barley and faba beans (\% DM)

\section{Starch}

The cultivation method influenced the content of starch being produced by the plant. In the case of wheat and barley, organic cultivation elevated the starch content in the grains. The difference between the production methods was significant in the case of barley. In contrast to that, organic production reduced the amount of starch in faba beans significantly (table 3 ).

Table 1: Starch content in wheat, barley and faba beans of conventional and organic cultivation (\% DM)

\begin{tabular}{|l|c|c|c|c|}
\hline Plant species & conventional & organic & Sig. & SEM \\
\hline Wheat $(\mathrm{n}=16)$ & 58.95 & 61.84 & 0.098 & 0.872 \\
Barley $(\mathrm{n}=6)$ & $49.79^{\mathrm{a}}$ & $52.38^{\mathrm{b}}$ & 0.033 & 0.634 \\
Faba bean $(\mathrm{n}=6)$ & $46.00^{\mathrm{b}}$ & $42.16^{\mathrm{a}}$ & 0.013 & 0.838 \\
\hline
\end{tabular}

Means in the same row with different superscripts are significantly different $(p<0.05)$. 


\section{Fiber fractions}

\section{$\underline{\mathrm{NDF} \text { and ADF }}$}

The cultivation method influenced the portion of NDF and ADF (figures 2 and 3). The amount of NDF was elevated for all three plant-species, wheat, barley and faba beans, when they were cultivated organically. The difference was tested to be significant in the case of wheat. The cultivation method did not show a clear effect considering the portion of ADF. Whereas, ADF content was higher in organically produced wheat and barley, the opposite occurred for faba beans. However, none of these differences were significant.

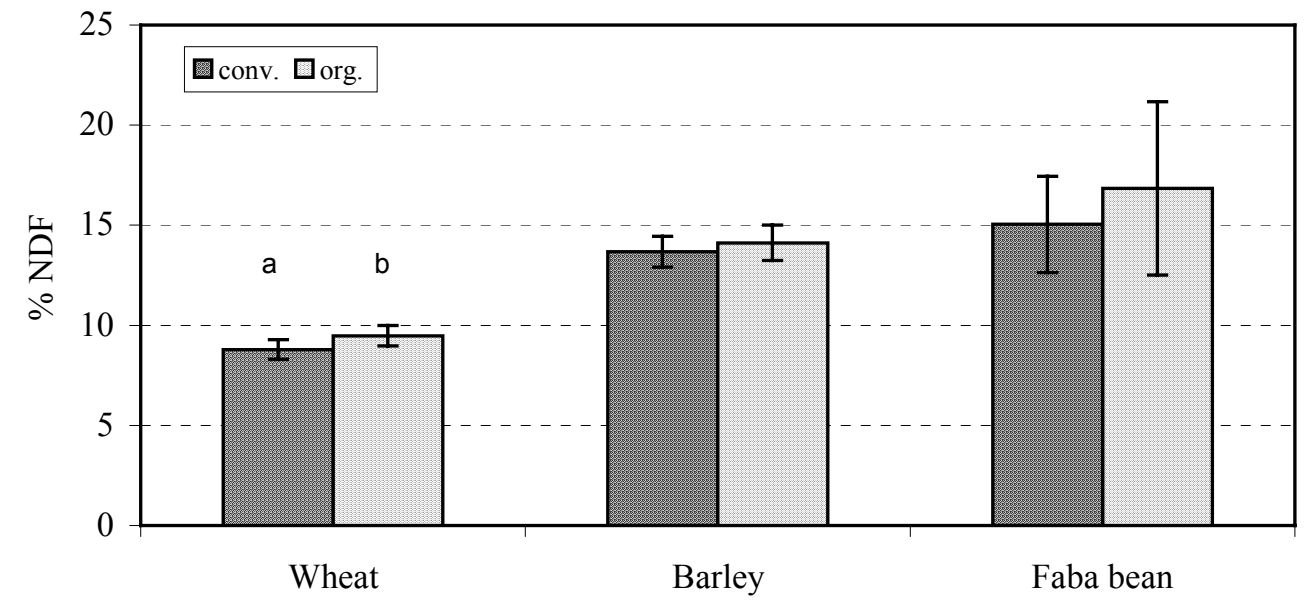

Figure 2: Influence of cultivation method on NDF content in wheat, barley and faba beans (\% DM) Means for the same plant species with different letters are significantly different $(p<0.05)$.

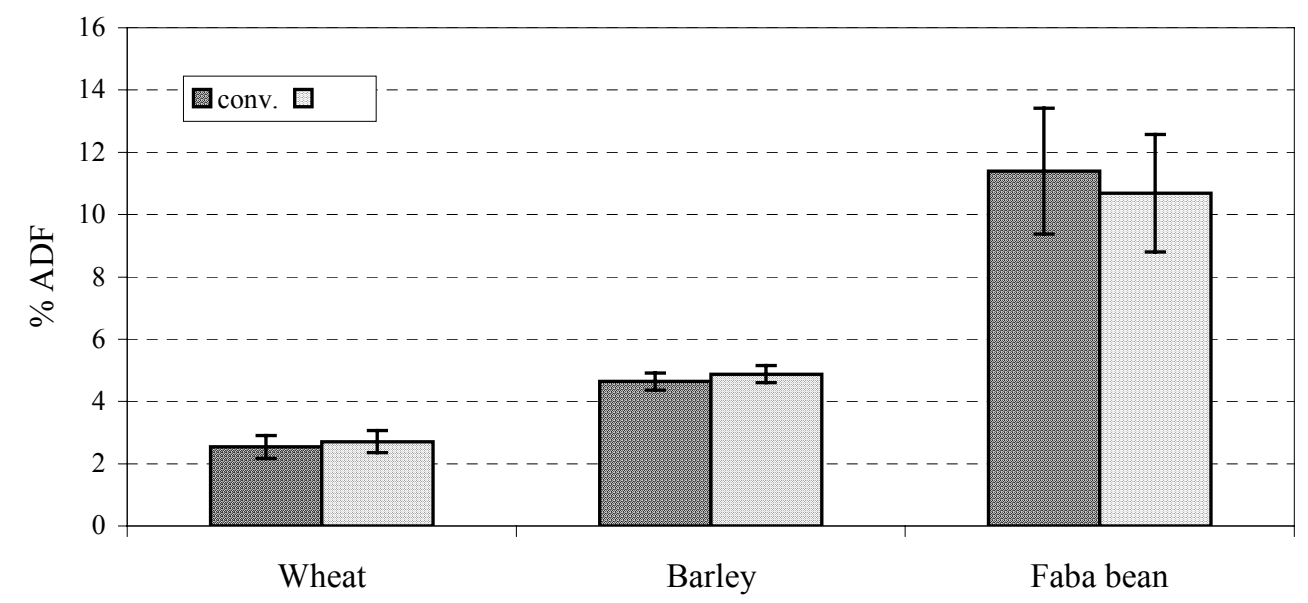

Figure 3: Influence of cultivation method on ADF content in wheat, barley and faba beans (\%DM) Means for the same plant species with different letters are significantly different $(p<0.05)$. 


\section{$\underline{\text { Pentosans }}$}

Pentosan content was only analyzed in wheat. The content of pentosans, which are considered to be part of the hemicellulose fraction, was reduced by organic production compared to conventional production as shown in table 4 . The difference was not significant.

Table 2: Pentosan content in wheat of conventional and organic cultivation (\% DM)

\begin{tabular}{|l|c|c|c|c|}
\hline Plant species & Conventional $(n=16)$ & Organic $(n=16)$ & Sig. & SEM \\
\hline Wheat & 5.88 & 4.58 & 0.092 & 0.384 \\
\hline
\end{tabular}

Means in the same row with different superscripts are significantly different $(\mathrm{p}<0.05)$.

\section{Glycosides}

The results with $1.21 \%$ and $1.16 \%$ glycoside content per g DM respectively show, that there was only a trend showing a higher glycoside content in faba beans of conventional cultivation compared to those being organically produced. However, the differences were not significant.

\section{Discussion}

There have been many studies on the influence of cultivation methods on chemical composition of plants. The basic flaw in all these investigations is, that most of authors do not distinguish between product and even plant groups. They merely address organic or conventional methods. Moreover, most literature concerning this theme is relatively old when compared to agricultural progress, meaning that results been found in the 60th-80th are hardly applicable to modern agriculture. Another problem is the different guidelines in different organic organizations could lead to different cultivation methods even among organic products.

To minimize these deficiencies, all products being tested in the present study were chosen in such a way that the same cultivar was grown organically and conventionally under identical conditions of climate, soil and year. However it might be difficult to compare results in the literature with the ones attained in this study.

The results of this study have shown that there is a variance in the proportion of single nutrients depending on the cultivation method.

The protein content, in particular, is known to be directly related to the cultivation method. Depending on the production means and the chosen fertilization method, organic or mineral, the protein content and protein composition can be influenced. The higher the amount of N- 
fertilization with the resulting faster $\mathrm{N}$-availability for the plant, the greater is the protein content (DELGADO et al., 1999). Since organic farming only uses organic manure, it can be assumed that the amount of nitrogen directly available to the plant is decreased compared to conventional farming. This would be expressed as a lower protein content in the plants.

This is supported by the results of this study, which show a lower protein content for wheat, barley and faba beans, when they were produced organically. These results are confirmed by most other studies, indicating an elevated protein content for products grown under conventional conditions, independent of the plant group considered (WOESE et al., 1995, 1997; Kumpulainen, 2001; Mølgaard, 2000; Williams, 2002). According to Andersen et al. (2001) protein contents of organically produced cereals are about $10-20 \%$ lower than in conventional products.

The results for wheat are in accordance with observations concerning the protein content of wheat (MINISTERIUM FÜR ERNÄHRUNG, LANDWIRTSCHAFT UND UMWELT BADENWÜrttemberg, 1977; Petterson, 1982; Dlouhy, 1981; Granstedt \& KJellenberg, 1995; SHIER et al., 1984, RAUPP et al., 1994; KIEFFER, 1995) and wheat flour (HAGLUND et al., 1998). A reduced protein content for barley as observed in the present study was also found by Dlouhy (1981) and Petterson (1982) observed a decreased protein content in organic barley, whereas no differences occurred in another study comparing cereal samples from both cropping systems (MINISTERIUM FÜR ERNÄHRUNG, LANDWIRTSCHAFT UND UMWELT BADENWÜRTTEMBERG, 1977).

As to faba beans, this is the first time showing an effect of the cultivation method on protein content in legume seeds.

Other studies (Dlouhy, 1981; Petterson, 1982; Granstedt \& KJellenberG, 1996; SCHELler, 1999, STEINECK \& LiebHARD, 1984) also found a lower protein content but a higher protein quality due to higher levels of some essential amino acids in organic products. In contrast to the protein content which increased with conventional farming, starch content decreased compared to organic production in the present study. This may be explained by the “C/N Balance Theory” described by BRANDT \& MøLGARD (2001). According to this theory, less N-containing ingredients but more carbohydrate rich ingredients such as starch and NSP are formed if, as in organic farming, $\mathrm{N}$-availability is low. Other studies, of those two only were concerning wheat, did not show a clear trend (HAGLUND et al., 1998; KLETT, 1968; KLEIN, 1968). However, two of these references are, due to their age, presumably not applicable to modern farming. HAGLUND et al. (1998) tested conventionally produced wheat 
flour against organically produced wheat flour and observed the same trend, i.e. higher starch contents in organically grown wheat, as found in the present study.

Organically grown wheat and barley contained more fiber than the same cultivar grown conventionally. This is in agreement with the few earlier results of other authors. BELDEROK (1978) and HaGLUND et al. (1998) found slightly higher fiber (NSP) contents in organically cultivated products. In both cereals of the present study NDF content was elevated to a slightly greater extend than ADF (figure 2), indicating an increase in hemicelluloses (NDF minus ADF) associated with the organic cultivation method. Pentosans, which belong to the hemicellulose fraction and which have been directly measured were decreased in organically produced wheat. Faba beans differed from the two cereals. The observed higher NDF- and lower ADF-contents indicate an increased content of hemicellulose as a result of producing faba beans organically. These results clearly point out plant-specific responses on the cultivation method and show that the effects on forming the nutritionally important complex of non-starch-polysaccharides should be investigated in more detail.

Glycosides constitute secondary plant constituents including the Vicia faba-specific pyrimidinglycosides vicine and convicine, which have been shown to exert strong antinutritional effects particularly in laying hens (ABEL et al., 2002). Direct analysis of vicin and convicin applying another specific HPLC-based method (QUEMENER, 1988) yield the same level (around 1-1.5\% DM) of conventional faba beans as determined for the total fraction of glycosides in this study. Glycoside content was not significantly influenced by the cultivation method. The full potential of faba beans as a protein and energy rich feed component in animal nutrition and in poultry nutrition in particular can therefore only be utilized if genetically low vicin /convicin varieties are introduced (HELSPER et al., 1993; BOND \& DuC, 1993; DuC et al., 1999).

In conclusion, the plant composition is significantly influenced by the cultivation method applied. Organically grown wheat, barley and faba beans contain less protein than the same cultivars grown conventionally. The obtained results of amino acid analysis do not justify awarding organically grown plant products a nutritionally superior protein quality. Organically cultivated wheat and barley contain more starch and fiber than the same cultivar produced conventionally. Organically grown faba beans contain less starch, more NDF and less ADF than the same cultivar grown conventionally, thereby increasing the content of hemicelluloses in particular. The three crops studied in this investigation constitute important feedstuffs and the observed cultivation-related changes in nutrient content as well as in fractional composition are expected to influence nutrient utilization by domestic animals. In 
the first instance digestive physiology of the animals will be influenced and these effects should be investigated in further studies.

\section{References}

Abel, HJ.; Rothenberger, L.G.; MAinKA, S., 2002. Ackerbohnen in der Tierernährung. Übersicht Tierernährung 30, 109-133

Andersen, J.-O.; O`Doherty Jensen, K.; Larsen, H.N.; Mølgaard, J.P., Tingstad, A.; MARCKMANN, P.; AstruP, A., 2001. Organic foods and human health. Proceedings of the European conference: Organic food and Farming, Copenhagen, 172-177

BELDEROK, B., 1978. Infloed van alternatieve landbouwmethoden bij de teelt van tarwe op de voedingswaarde en de verwerkingseigenschappen. Voeding 39, 352-356

BIOLAND, 2001. Bioland Richtlinien, www.bioland.de/bioland/richtlinien/erzeugerrichtlinien.pdf, March 2004

BOND; D.A. \& DuC, G., 1993. Plant breeding as a means of reducing antinutritional factors in grain legumes. In :VAn Der Poel, A.F.B.; Huisman, J.; SAINI, H.S. (Eds.) EAAP Publication Wageningen 70, 379-396

BRAND, K. \& MølgaARD, J.P., 2001. Organic agriculture: does it enhance or reduce the nutritional value of plant foods. Journal of Science of Food and Agriculture 81, $924-$ 931

BUNDESMINISTERIUM FÜR VERBRAUCHERSCHUTZ, ERNÄHRUNG UND LANDWIRTSCHAFT, 2004. Verordnung (EWG) Nr. 2092/91 (EG-Öko-Verordnung) und Folgerecht. www.verbraucherministerium.de/indexCC50A5785E6947818086B26C12A90287.html

Delgado, E.; Möller, K.; PAWelziK, E., 1999. Influence of nitrogen Fertilization on protein quality of rye and oat grains. Agribiological Research 52, 337-345

DEMETER, 2002. Richtlinien Erzeugung. www.demeter.de/demeter/dem_richtlinien.pdf, March 2004

DLOUHY, J., 1981. Alternativa odlingsformer-växtprodukters kvalität vid konventionell och biodynamisk odling, Sveriges Lantbruksuniversitet, Institut för växtodling, Rapport 91, Uppsala

Duc, G.; Marget, P.; Esnault; R.; Le Guen, J.; Bastanelli, D., 1999. Genetic variability for feeding value of faba bean seeds (Vicia faba): comparative chemical composition of isogenics involving zero-tannin and zero-vicine genes. Journal of Agricultural Sciences 133, 185-196 
Goering, H.K. \& VAN Soest, P.J., 1970. Forage fiber analysis. Apparatus, reagents, procedures and some applications. Agricult. Handbook No. 379, Agricultural Research Service, Dep. of documents, US Government Printing off., Washington, DC, 20 pages

Gransted, A.G.\& KJellenBerG, L., 1996. Quality investigations with the K-trial Järna, and other Scandinavian fertilization experiments. In: RAUPP, J. (Ed.). Quality of plant products grown with manure fertilization: Fertilization systems in organic farming. (Concerted action AIR3-CT94-1940) Meeting Juva, Finland, 1996, 3-12

Haglund, Å.; JohAnsson, L.; DAhlstedT, L., 1998. Sensory evaluation of wholemeal bread from ecologically and conventionally grown wheat. Journal of Cereal Science 27, 199207

Helsper, J.P.F.G.; HoOgendiJK, J.M.; VAn Norel, A.; Burger-MeiJer, K.; 1993. Antinutritional factors in faba beans (Vicia faba L.) as affected by breeding toward the absence of condensed tannins. Journal of Agriculture and Food Chemistry 41, 10581061

KIEFFER, M., 1995. Untersuchungen zur Unterscheidbarkeit von Weizen aus ökologischem und konventionellem Anbau. Dissertation, Universität Bonn

KLEIN, J.,1968. Der Einfluss verschiedener Düngungsarten in gestaffelter Dosierung auf Qualität und Haltbarkeit pflanzlicher Produkte. Institut für Biologisch-Dynamische Forschung Darmstadt

KLETT, M., 1968. Untersuchungen über Licht- und Schattenqualität in Relation zum Anbau und Test von Kieselpräparaten zur Qualitätserhebung. Institut für BiologischDynamische Forschung Darmstadt

Kumpulainen, J., 2001. Nutritional and toxicological quality comparisons between organically and conventionally grown foodstuffs. Proceedings / International Fertilizer Society Nr. 472

MINISTERIUM FÜR ERNÄHRUNG, LANDWIRTSCHAFT UND UMWELT BADEN-WÜRTTEMBERG, 1977. Auswertung dreijähriger Erhebungen in neun biologisch-dynamisch wirtschaftenden Betrieben, Stuttgart

MølgAARD, J.P., 2000. Nutrients, secondary metabolites and foreign compounds in organic foods. In: AlföldI, T.; LockereTZ, W.; Niggli, U. (Eds.), Proceedings 13th International IFOAM Scientific Conference, 313

NATURLAND, 2002. Naturland Richtlinien. www.naturland,de/n2/Naturland\%20Richtlinie_Juli2002_III.pdf

NAUMANN, C.\& BASSLER, R., 1976-1997. Die chemische Untersuchung von Futtermitteln, Methodenbuch, volume 3 with supplements 1983, 1988 and 1993, loose-leave collection., VDLUFA-Verlag Darmstadt

PetTerson, B.D., 1982. Konventionell und biologisch dynamisch erzeugte pflanzliche Nahrungsstoffe im Vergleich. Angewandte Wissenschaften. 263, 218-228 
QUEMENER, B., 1988. Determination of vicine and convicine in fababeans by high pressure liquid chromatography. Journal of the Science of Food and Agriculture 32, 1163-1171

RAUPP, J.; REENTS, H.J.; BACHINGER, J., 1994. Ertrag und Qualität von Sommerweizen bei organischer und mineralischer Düngung an einem trocken-warmen Standort. Mitteilungen der Gesellschaft für Pflanzenbauwissenschaften 7, 253-256

RAUPP, J., 1996. Quality investigations with products of the long term fertilization trial in Darmstadt. In: RAUPP, J. (Ed.). Quality of plant products grown with manure fertilization: Fertilization systems in organic farming. (Concerted action AIR3-CT941940) Meeting Juva, Finland, 1996, 13-33

Scheller, E., 1999. Proteinqualität bei Weizen, Dinkel und Einkorn. In: HoffmanN, H. \& MülLER, S. (Eds.), Beiträge zur 5. Wissenschaftstagung zum ökologischen Landbau, Humboldt Universität Berlin, 121-125

Schuster, M., Mowarid, M., SATTES, H., 1991. Verbrennungsmethode nach Dumas zur Bestimmung des Proteingehaltes in Futtermitteln. VDLUFA Verlag 33, 445-450

Shier, N.W.; Kelman, I.; Dunson, J.W., 1984. A comparison of crude protein, moisture, ash and crop yield between organic and conventionally grown wheat. Nutrition Reports International $30(1), 71-76$

SteineCK, O. \& LiEBHARD, P., 1984. Qualität und Ertrag von Brotgetreide aus naturwissenschaftlich-biologischer und alternativ-biologischer Pflanzenproduktion. Allgemeiner Mühlen-Markt 85, 35-40

Thomann, R. \& Schreinemann, K., 1982. Eine günstige Bestimmungsmethode für lösliche Pentosane. Nahrung 26, 515-518

WiLLIAMS, C., 2002. Nutritional quality of organic food: Shades of gray or shades of green? Proceedings of the Nutrition Society 61 (1), 19-24

Woese, K.; Lange, D.; Boess, C.; BöGL, K.W., 1995. Ökologisch und konventionell erzeugte Lebensmittel im Vergleich. Eine Literaturstudie. Teil I+II, BGVV Heft 5, Bundesinstitut für gesundheitlichen Verbraucherschutz und Veterinärmedizin, Berlin.

Woese, K.; Lange, D.; Boess, C.; BöGL, K.W., 1997. A comparison of organically and conventionally grown foods- results from a review of the relevant literature. Journal of the Science of Food and Agriculture 74, 281-293 


\title{
Study 2
}

\section{Fiber-related digestive processes in different breeds of pigs}

\begin{abstract}
In a 2 factorial experiment three different pig breeds, (Schwäbisch Hällisches Schwein (SH), Buntes Bentheimer Schwein (BB) and crossbreed pig (CB)) each with 12 animals and two diets differing in BFS content (basal diet (B) and basal diet + sugar beet pulp (SBP)) were tested for their influence on water holding capacity (WHC) of intestinal content, digestibility, $\mathrm{N}$-metabolism and mineral balances. Basal diet was calculated to meet $80 \%$ of energy and $100 \%$ of N-requirement. This was in order to give pigs which were fed the SBP diet the opportunity to use energy from fiber for N-retention. Pigs had an average weight of $37.9 \pm$ $5.3 \mathrm{~kg}$ and were housed individually in metabolism cages, which allowed separate collection of feces and urine. Feeding the SBP diet resulted in elevated WHC and lower nutrient digestibility except for crude fiber, NDF and ADF, which showed elevated digestibility. Fecal $\mathrm{N}$ and bacterial protein excretion were increased with the SBP diet. The breed influenced fiber digestibility. $\mathrm{BB}$ showed the highest level of crude fiber and along with $\mathrm{CB}$ pigs the highest level of NDF digestibility. Fecal $\mathrm{N}$ excretion in terms of $\mathrm{g}$ per $\mathrm{kg}$ metabolic body weight and day was not significantly different between the breeds, but urine $\mathrm{N}$ excretion was highest for SH pigs. The fraction of bacterial and endogenous debris $\mathrm{N}$ was also highest for SH. Mineral balances were influenced by diet and breed. Interactions between the factors diet and breed did not occur.
\end{abstract}

\section{Introduction}

Pigs do not have the ability to break down dietary fiber due to a lack of endogenous Bglycosidic enzymes. For their utilization, these components, mostly consisting of cellulose, hemicelluloses and lignin, need to be fermented by microbes in the intestinal tract of the animal. This means, fiber is present during most digestive processes considering other nutrients such as sugar, starch, protein and fat and consequently do affect these processes. Many experiments have shown influences of different kind of fibers on digestion and absorption of other nutrients.

Increased secretion of digestive juices and intensified microbial synthesis results in a decreased apparent nutrient digestibility (BOISEN \& FERNÁNDES, 1995; DE LANGE et al., 1990; FurdA, 1990; KreUZER et al., 1991; Le GofF et al., 2001; LETERME et al., 2000; 
Mosenthin et al., 1992; MrOz et al., 2000). But dietary fiber does also affect true digestibility by reducing digestion and absorption of different nutrients. This is mainly caused by influencing enzyme-substrate interaction due to the cellular structure of dietary fiber and its ability to build complexes with other nutrients (GRALA et al., 1999). Changes in enzyme activity are also reported (FURDA, 1990, JOHNSON, 1992; MADAR \& ODES, 1992; MOSENTHIN \& SAUER, 1993).

Furthermore fiber affects digestibility by changing digesta retention time. This is prolonged in the small intestine when feeding high fiber diets containing soluble fiber, whereas passage rate is shortened by this type of fiber in the caecum and large intestine (BAKKER et al., 1998; Johansen et al., 1996; JohAnSEn \& BACH KNUdSEn, 1994; Kestling et al., 1991; Low, 1990; MiQuel et al., 2001; PotKins, 1991. Changes in retention time are mainly caused by higher digesta viscosity due to a higher water binding capacity and higher amount of digestive juices being secreted when feeding soluble NSP in particular.

Consequent selection on high daily body weight gains and high efficiency of feed utilization combined with feeding concentrated feedstuff may have led to changes in length and relative proportions of different sections of the intestinal tract resulting in different caecal and precaecal digestive contributions. This might result in different effective break down of fiber components and their utilization between modern and old pig breeds.

The purpose of this experiment was to analyze the effect of fiber on digesta water holding capacity of intestine contents, digestibility of nutrients, nitrogen and mineral balances in different breeds of pigs when feeding a diet with or without sugar beet pulp supplement.

\section{Methods and material}

\section{Metabolic trial}

\section{Animals}

Fiber-related digestive processes were studied in castrated male pigs of three different breeds, each with 12 animals (3 repetitions with 4 animals). Experimetal animals were two local breeds "Buntes Bentheimer Schwein" (BB), "Schwäbisch Hällisches Schwein" (SH) and a modern crossbreed pig (CB; (Landrace x Large White) x Pietrain), received from their breeding organizations. The total experimental period was divided into a seven-day adaptation period and a five-day collection period.

Animals were weighed with the beginning of the adaptation period and with the beginning and end of the collection period. At the beginning of the adaptation period, pigs had an 
average weight of $33.9 \mathrm{~kg} \pm 4.4$ and a weight of $37.9 \mathrm{~kg} \pm 5.3$ at the beginning of the collection period. Calculation basis for metabolic body weight was the weight at the beginning of the collection period.

\section{Feeding and housing of animals}

Upon arrival, pigs were first kept in a pigpen for one week in order to recover from transport stress. After that pigs were housed individually in metabolism cages, which assured an exact feed allotment and allowed separate collection of feces and urine and feed residues. Water was offered ad libitum. Room temperature during the metabolism trial was $22^{\circ} \mathrm{C}$.

The components and ingredients of the experimental diets are shown in table 1 and 2.

Basal diet was composed of easily digestible feed components while a supplemental diet consisted of the basal diet plus dried sugar beet pulp. Basal diet was calculated to meet $80 \%$ of the energy requirement and $100 \%$ of protein and amino acid requirement for $700 \mathrm{~g}$ average daily body weight gains (DLG/2002). Amino acids were supplemented according to the concept of ideal protein (ROTH et al., 1993; WANG \& FULLER, 1989).

Pigs were fed twice daily at $8 \mathrm{pm}$ and $4 \mathrm{am}$. Referred to the pigs weight and average daily body weight gain, as ascertained in the adaptation period, basal diet was fed at a rate of $0.076 \mathrm{~kg}$ and basal diet plus SBP at a rate of $0.095 \mathrm{~kg} / \mathrm{kg}$ metabolic body weight and day. The daily amount of feed was divided into two equal portions. Before feeding feed was mixed with water to achieve loss-free intake. Actually realized feed intake was $100 \%$ for basal diet and $98 \%$ for supplemental diet. Feed residues during the collection period were weighed and stored for analysis.

At the end of the experiment pigs were slaughtered after overnight fasting and their intestine content used for further experiments.

Table 1: Components of the experimental diets (\%)

\begin{tabular}{|l|c|c|}
\hline & Basal diet & Basal Diet+ SBP \\
\hline Wheat & 40.00 & 32.00 \\
Barley & 29.75 & 23.80 \\
Soy bean meal & 20.00 & 16.00 \\
Potato protein & 5.00 & 4.00 \\
Premix & 3.00 & 2.40 \\
Soy bean oil & 2.00 & 1.60 \\
L-Lysine HCL & 0.17 & 0.136 \\
DL-Methionine & 0.06 & 0.048 \\
L-Threonine & 0.02 & 0.016 \\
Sugar beet pulp & & 20.00 \\
\hline
\end{tabular}

Per kg Premix: 24\% Ca, 5\% P, 5\% Na, 1\% Mg, Additives: 400000 I.U. Vit.A, 40000 I.U. Vit.D3, 2000mg Vit.E, $500 \mathrm{mg} \mathrm{Cu}$ 
Table 2: DM content (\%) and ingredients (\% DM) of the experimental diets

\begin{tabular}{|l|c|c|}
\hline & Basal diet & SBP-diet \\
\hline Dry matter (\%) & 88.63 & 88.52 \\
Organic matter & 95.13 & 94.52 \\
Ash & 4.87 & 5.48 \\
Crude protein & 24.13 & 21.13 \\
Ether extract & 3.88 & 3.26 \\
Crude fiber & 3.25 & 5.83 \\
N-free extract & 63.87 & 64.30 \\
Starch & 43.99 & 35.88 \\
Sugar & 4.23 & 5.99 \\
NDF & 13.29 & 18.60 \\
ADF & 4.48 & 7.94 \\
ADL & 2.56 & 3.03 \\
Cellulose & 1.92 & 4.91 \\
Hemicellulose & 8.81 & 10.66 \\
\hline BFS & 11.69 & 19.64 \\
ME [MJ/kg DM] & 15.46 & 13.99 \\
\hline
\end{tabular}

\section{Sample collection and conditioning}

Feed samples were taken at the beginning of the experimental period and before weighing out daily feed amounts. Samples were ground to a particle size of $0.5 \mathrm{~mm}$ and stored in a dry place for analysis.

The feces were collected and weighed twice daily after feeding and stored at a frozen state at $-20^{\circ} \mathrm{C}$. At the end of the collection period total feces of each animal were homogenized with a cutter (EMS, Eduard Müller\& Söhne, Saarbrücken) and dry matter content and protein were determined immediately. A subset of feces was frozen again and stored at $-20^{\circ} \mathrm{C}$ for further analysis.

Urine was collected and weighed once daily. In order to reduce ammonia-N losses, $150 \mathrm{ml}$ of $30 \%$ sulphuric acid were given in the collection bottle. An aliquot of $10 \%$ of daily urine excretion was taken and frozen at $-20^{\circ} \mathrm{C}$.

Jejunum-, caecum- and colon- content for the determination of water holding capacity (WHC) was collected immediately after slaughtering the pigs and kept on ice during transport to the laboratory.

\section{Analyses}

WHC

Samples of jejunum-, caecum and colon content were transferred to centrifugation tubes. Tubes were weighed and centrifuged at $14926 \mathrm{~g}$ for $20 \mathrm{~min}$. The supernatant fraction was removed by suction. Then the tubes were turned upside down in order to drain off residual 
supernatant fraction for one hour before being re-weighed. The fraction of digesta $(\mathrm{g} / \mathrm{kg})$ present in the sediment was calculated. Tubes were dried in an oven at $60^{\circ} \mathrm{C}$ for 12 hours and weighed again to determine their DM content.

The WHC ( $\mathrm{g}$ water/ $\mathrm{g}$ dry weight) of the digesta was calculated as:

$\mathrm{WHC}=\underline{\text { (Weight before drying- Dry weight) }}$

Dry weight

\section{Weende Analysis}

Feed, feed residues, feces and urine were analyzed according to the Weende analysis.

Protein determination was carried out with homogenized fresh feces. For all other analyses feces were dried at $60^{\circ} \mathrm{C}$ and ground to $0,5 \mathrm{~mm}$.

NDF, ADF and ADL were determined in an ANKOM Fiber Analyzer according to the method of GOERING\& VAN SOEST (1970).

Starch and sugar

Starch content in the diet was determined polarimetrically according to the VDLUFA Verbandsmethode, sugar content was determined according to the method of Luff- Schorl (NAUMANN\& BASSLER, 1976).

\section{Minerals}

Mineral analyses in feed, feed residues, feces and urine were carried out after pressure digestion with $65 \%$ concentrated $\mathrm{HNO}_{3}$ according to the method of LOFTFIELD \& BEESE (1999). The elements sodium, potassium, magnesium, phosphorus and sulphur were determined with ICP-AES (Inductively coupled plasma atom emission spectrometer; Spectro Analytical Instruments, Kleve, Germany).

\section{Fecal N-fractions}

Partitioning of fecal $\mathrm{N}$ was carried out according to the method originally developed for ruminants by MASON (1969) and modified for pig feces by KREUZER et al. (1989) and MACHMÜLLER (1994). This method allows a chemi-physical separation of fecal nitrogen into undigested dietary nitrogen, bacterial nitrogen and endogenous nitrogen. NDF insoluble $\mathrm{N}$ is considered to represent real undigested dietary N (UDN). Water-soluble N (WSN), which is analyzed in the supernatant after centrifugation of feces, less the UDN gives the amount of bacterial and endogenous dietary $\mathrm{N}(\mathrm{BEDN})$. BEDN excretion was assumed to consist 
exclusively of bacterial $\mathrm{N}$ and therefore allows the calculation of bacterial protein (BP) per $100 \mathrm{~g}$ bacterially fermented substrate (BFS) as an index for the efficiency of protein synthesis.

Urea and Creatinin

Urea and creatinin content in urine samples of all animals were analyzed enzymatically and by means of a kinetic UV-test in Clinicum of Göttingen University.

\section{Calculations and statistics}

Dietary ME and BFS contents were calculated from digestibility measurements. BFS was calculated as the proportion of digested crude fiber and $\mathrm{N}$-free extract exclusive starch and sugar contained in the feed.

Data evaluation was performed using SPSS 10.0 program. Data were analyzed as block randomized. All data were tested by analysis of variance considering diets and breeds as factors. If $\mathrm{F}$ values in the analysis of variance were significant, mean values were analyzed with the Tukey multi comparison test.

If there were interactions between diet and breed, each, breed and diet were tested individually by analysis of variance.

\section{Results}

\section{Water binding capacity and bulking properties}

The addition of SBP resulted in an increased excretion of fecal bulk per day. There was an insignificant trend for CB having the highest amounts of fecal bulk.

WHC was higher when the SBP diet was fed, but was not influenced by the breed. As expected, WHC was different in different parts of the intestinal tract. It was lowest in the colon and significantly higher in the caecum and jejunum.

Table 3: Influence of diet and pig breed on bulking properties and WHC (g water/g DM) in different intestinal parts

\begin{tabular}{|c|c|c|c|c|c|c|c|}
\hline & \multicolumn{2}{|c|}{ Diet } & \multicolumn{3}{|c|}{ Breed } & \multirow[b]{2}{*}{$\begin{array}{l}\text { Inter- } \\
\text { action }\end{array}$} & \multirow[b]{2}{*}{ SEM } \\
\hline & $\begin{array}{c}\text { Basal } \\
(n=18)\end{array}$ & $\begin{array}{c}\text { SBP } \\
(\mathrm{n}=18)\end{array}$ & $\underset{(n=12)}{\mathbf{S H}}$ & $\begin{array}{c}\mathbf{B B} \\
(\mathrm{n}=12)\end{array}$ & $\underset{(n=12)}{\mathbf{C B}}$ & & \\
\hline Fecal bulk $\left(\mathrm{g} / \mathrm{kg}^{0.75}\right)$ & $159.4^{\mathrm{a}}$ & $310.0^{b}$ & 217.1 & 235.8 & 250.9 & 0.225 & 14.650 \\
\hline WHC jejunum & $4.46^{\mathrm{a}}$ & $6.61^{\mathrm{b}}$ & 5.67 & 5.52 & 5.51 & 0.125 & 0.225 \\
\hline WHC caecum & $4.29^{\mathrm{a}}$ & $6.94^{\mathrm{b}}$ & 5.67 & 5.72 & 5.46 & 0.458 & 0.253 \\
\hline WHC colon & $2.98^{\mathrm{a}}$ & $3.94^{\mathrm{b}}$ & 3.37 & 3.52 & 3.50 & 0.795 & 0.094 \\
\hline
\end{tabular}

Different superscripts within the same row show significant differences $(p<0.05)$. 


\section{Digestibility}

The effects of diet and pig breed on Weende nutrient digestibility are shown in table 4 . There was no interaction between diet and breed. Digestibility was significantly influenced by the diet. Except for crude fiber, feeding the SBP diet resulted in significantly reduced digestibilities. The strongest influence was observed for crude protein and ether extract, showing reductions of 7.5 and $9.4 \%$ points respectively. Pig breed influenced crude fiber digestibility, with lowest values for $\mathrm{SH}$ and highest for BB pigs. Ash digestibility was lowest for SH and highest for CB pigs. All other nutrients were not significantly affected.

Table 4: Influence of diet and pig breed on nutrient digestibility (\%)

\begin{tabular}{|c|c|c|c|c|c|c|c|}
\hline & \multicolumn{2}{|c|}{ Diet } & \multicolumn{3}{|c|}{ Breed } & \multirow{2}{*}{$\begin{array}{l}\text { Inter- } \\
\text { action }\end{array}$} & \multirow[b]{2}{*}{ SEM } \\
\hline & $\begin{array}{c}\text { Basal } \\
(\mathrm{n}=18)\end{array}$ & $\begin{array}{c}\text { SBP } \\
(\mathrm{n}=18)\end{array}$ & $\begin{array}{c}\text { SH } \\
(\mathrm{n}=12)\end{array}$ & $\begin{array}{c}\text { BB } \\
(n=12)\end{array}$ & $\begin{array}{c}\mathbf{C B} \\
(\mathrm{n}=12)\end{array}$ & & \\
\hline$\overline{D M}$ & $86.2^{b}$ & $83.0^{\mathrm{a}}$ & 84.3 & 84.6 & 84.9 & 0.197 & 0.342 \\
\hline OM & $87.9^{b}$ & $85.0^{\mathrm{a}}$ & 86.2 & 86.5 & 86.7 & 0.203 & 0.307 \\
\hline $\mathbf{C P}$ & $87.3^{b}$ & $79.8^{\mathrm{a}}$ & 84.1 & 83.0 & 83.6 & 0.359 & 0.759 \\
\hline EE & $64.5^{\mathrm{b}}$ & $55.1^{\mathrm{a}}$ & 59.5 & 58.4 & 61.4 & 0.188 & 1.117 \\
\hline $\mathrm{CF}$ & $32.4^{\mathrm{a}}$ & $54.5^{\mathrm{b}}$ & $40.3^{\mathrm{a}}$ & $46.3^{\mathrm{b}}$ & $43.7^{\mathrm{ab}}$ & 0.136 & 2.012 \\
\hline $\mathbf{C A}$ & $53.7^{b}$ & $49.2^{\mathrm{a}}$ & $48.9^{\mathrm{a}}$ & $51.8^{\mathrm{ab}}$ & $53.6^{b}$ & 0.204 & 0.771 \\
\hline NfE & $92.2^{b}$ & $90.7^{\mathrm{a}}$ & 91.4 & 91.3 & 91.6 & 0.311 & 0.189 \\
\hline
\end{tabular}

Different superscripts within the same row show significant differences $(p<0.05)$.

The influence of diet and breed on ADF and NDF degradation in pigs is shown in table 5. The addition of fiber led to a higher amount of digested NDF and ADF and to higher NDF and ADF digestibility. The breed showed a significant influence on NDF digestibility. Highest digestibility for NDF was determined for $\mathrm{BB}$ and $\mathrm{CB}$ pigs. A trend for higher fiber digestibility with these two breeds was also observed for ADF but was not tested significant.

Table 5: Influence of diet and pig breed on the amount of consumed and digested fiber $\left(\mathrm{g} / \mathrm{kg}{ }^{0.75}\right)$ and on fiber digestibility $(\%)$

\begin{tabular}{|l|c|c|c|c|c|c|c|}
\hline & \multicolumn{2}{|c|}{ Diet } & \multicolumn{3}{c|}{ Breed } & Inter- & SEM \\
& $\begin{array}{c}\text { Basal } \\
(\mathrm{n}=18)\end{array}$ & $\begin{array}{c}\text { SBP } \\
(\mathrm{n}=18)\end{array}$ & $\begin{array}{c}\text { SH } \\
(\mathrm{n}=12)\end{array}$ & $\begin{array}{c}\text { BB } \\
(\mathrm{n}=12)\end{array}$ & $\begin{array}{c}\text { CB } \\
(\mathrm{n}=12)\end{array}$ & action & SEM \\
\hline NDF intake & $9.3^{\mathrm{a}}$ & $15.8^{\mathrm{b}}$ & 12.7 & 12.5 & 12.5 & 0.065 & 0.566 \\
\hline ADF intake & $3.1^{\mathrm{a}}$ & $6.8^{\mathrm{b}}$ & 5.0 & 4.9 & 4.9 & 0.088 & 0.309 \\
\hline NDF digested & $5.4^{\mathrm{a}}$ & $10.1^{\mathrm{b}}$ & 7.6 & 7.9 & 7.9 & 0.548 & 0.408 \\
NDF digestibility & $58.2^{\mathrm{a}}$ & $64.1^{\mathrm{b}}$ & $58.7^{\mathrm{a}}$ & $62.3^{\mathrm{b}}$ & $62.5^{\mathrm{b}}$ & 0.610 & 0.777 \\
\hline ADF digested & $1.1^{\mathrm{a}}$ & $3.6^{\mathrm{b}}$ & 2.3 & 2.4 & 2.3 & 0.109 & 0.211 \\
ADF digestibility & $36.0^{\mathrm{a}}$ & $52.7^{\mathrm{b}}$ & 42.2 & 45.8 & 45.1 & 0.216 & 1.827 \\
\hline
\end{tabular}

Different superscripts within the same row show significant differences $(\mathrm{p}<0.05)$.

\section{N-balances and fecal N-fractions}

$\mathrm{N}$-balances (table 6) and fecal N-fractions (table 7) did not show any interaction between diet and breed. Feeding the SBP diet led to a higher N-intake and was associated with higher fecal $\mathrm{N}$-excretion and N-retention (table 6). The elevated fecal $\mathrm{N}$-excretion was overcompensated 
by a significantly reduced urinary $\mathrm{N}$-excretion. There was no significant influence of the breed on fecal $\mathrm{N}$-excretion observed, whereas the amount of urine $\mathrm{N}$ was highest for $\mathrm{SH}$ and lowest for CB pigs.

N-retention also differed significantly among the breeds, with SH having the lowest and CB having the highest amount of $\mathrm{N}$ retained.

Table 6: Influence of diet and pig breed on N-balances during metabolism trial

\begin{tabular}{|c|c|c|c|c|c|c|c|}
\hline & \multicolumn{2}{|c|}{ Diet } & \multicolumn{3}{|c|}{ Breed } & \multirow{2}{*}{$\begin{array}{l}\text { Inter- } \\
\text { action }\end{array}$} & \multirow[b]{2}{*}{ SEM } \\
\hline & $\begin{array}{c}\text { Basal } \\
(n=18)\end{array}$ & $\begin{array}{c}\text { SBP } \\
(n=18)\end{array}$ & $\begin{array}{c}\mathbf{S H} \\
(n=12)\end{array}$ & $\begin{array}{c}\text { BB } \\
(n=12)\end{array}$ & $\begin{array}{c}\mathbf{C B} \\
(\mathrm{n}=12) \\
\end{array}$ & & \\
\hline Intake $\left(\mathrm{g} / \mathrm{d}^{*} \mathrm{~kg}^{0.75}\right)$ & $2.69^{\mathrm{a}}$ & $2.89^{\mathrm{b}}$ & 2.81 & 2.78 & 2.78 & 0.090 & 0.019 \\
\hline Excretion & & & & & & & \\
\hline Feces $\left(g / d^{*} k^{0.75}\right)$ & $0.34^{\mathrm{a}}$ & $0.58^{\mathrm{b}}$ & 0.45 & 0.48 & 0.46 & 0.478 & 0.023 \\
\hline$\%$ of intake & $12.71^{\mathrm{a}}$ & $20.17^{b}$ & 15.93 & 17.02 & 16.38 & 0.359 & 0.759 \\
\hline Urine $\left(\mathrm{g} / \mathrm{d}^{*} \mathrm{~kg}^{0.75}\right)$ & $1.12^{\mathrm{b}}$ & $0.84^{\mathrm{a}}$ & $1.08^{\mathrm{b}}$ & $0.96^{\mathrm{ab}}$ & $0.91^{\mathrm{a}}$ & 0.552 & 0.034 \\
\hline$\%$ of intake & $41.70^{\mathrm{b}}$ & $29.21^{\mathrm{a}}$ & $38.69^{b}$ & $34.64^{\mathrm{ab}}$ & $33.04^{\mathrm{a}}$ & 0.451 & 1.389 \\
\hline Retention $\left(\mathrm{g} / \mathrm{d}^{*} \mathrm{~kg}^{0.75}\right)$ & $1.23^{\mathrm{a}}$ & $1.46^{\mathrm{b}}$ & 1.28 & 1.35 & 1.41 & 0.165 & 0.032 \\
\hline$\%$ of intake & $45.59^{\mathrm{a}}$ & $50.61^{\mathrm{b}}$ & $45.37^{\mathrm{a}}$ & $48.34^{\mathrm{ab}}$ & $50.58^{b}$ & 0.216 & 0.978 \\
\hline
\end{tabular}

Different superscripts within the same row show significant differences $(p<0.05)$.

Fecal $\mathrm{N}$ fractions are shown in table 7. The addition of SBP resulted in an increase of WSN and UDN. Feeding the SBP diet also significantly increased BEDN excretion in g per $\mathrm{kg} 0.75$, whereas the proportion of BEDN decreased. The amount of bacterial protein per $100 \mathrm{~g}$ BFS also decreased when feeding the high fiber diet. There was also an influence of the breed on fecal N-fractions observed. CB pigs showed a significant higher portion of WSN and less BEDN compared to SH pigs. The UDN fraction showed a non-significant trend to highest values for $\mathrm{CB}$ pigs.

Table 7: Influence of diet and pig breed on total $\mathrm{N}\left(\mathrm{g} / \mathrm{d}^{*} \mathrm{~kg}^{0.75}\right)$, on the amount and proportion (\%) of $\mathrm{N}$-fractions and on the amount of BP ( $\mathrm{g}$ per $100 \mathrm{~g}$ BFS) in feces

\begin{tabular}{|c|c|c|c|c|c|c|c|}
\hline & \multicolumn{2}{|c|}{ Diet } & \multicolumn{3}{|c|}{ Breed } & \multirow[b]{2}{*}{$\begin{array}{l}\text { Inter- } \\
\text { action }\end{array}$} & \multirow[b]{2}{*}{ SEM } \\
\hline & $\begin{array}{c}\text { Basal } \\
(n=18)\end{array}$ & $\begin{array}{c}\text { SBP } \\
(n=18)\end{array}$ & $\begin{array}{c}\mathbf{S H} \\
(\mathrm{n}=12)\end{array}$ & $\begin{array}{c}\text { BB } \\
(n=12)\end{array}$ & $\begin{array}{c}\mathbf{C B} \\
(\mathrm{n}=12)\end{array}$ & & \\
\hline TN & $0.34^{\mathrm{a}}$ & $0.58^{\mathrm{b}}$ & 0.45 & 0.48 & 0.46 & 0.478 & 0.023 \\
\hline $\begin{array}{l}\text { WSN }\left(\mathrm{g} / \mathrm{d}^{*} \mathrm{~kg}^{0.75}\right) \\
\text { WSN (\% of fecal N)}\end{array}$ & $\begin{array}{l}0.07^{\mathrm{a}} \\
19.3^{\mathrm{a}}\end{array}$ & $\begin{array}{l}0.13^{\mathrm{b}} \\
22.9^{\mathrm{b}}\end{array}$ & $\begin{array}{c}0.08 \\
17.8^{\mathrm{a}}\end{array}$ & $\begin{array}{c}0.10 \\
21.5^{\mathrm{ab}}\end{array}$ & $\begin{array}{c}0.11 \\
24.0^{\mathrm{b}}\end{array}$ & $\begin{array}{l}0.672 \\
0.954\end{array}$ & $\begin{array}{l}0.008 \\
0.849\end{array}$ \\
\hline $\begin{array}{l}\text { UDN }\left(\mathrm{g} / \mathrm{d}^{*} \mathrm{~kg}^{0.75}\right) \\
\text { UDN (\% of fecal N)}\end{array}$ & $\begin{array}{l}0.05^{\mathrm{a}} \\
13.9^{\mathrm{a}}\end{array}$ & $\begin{array}{l}0.14^{\mathrm{b}} \\
24.6^{\mathrm{b}}\end{array}$ & $\begin{array}{l}0.08 \\
16.7\end{array}$ & $\begin{array}{l}0.09 \\
19.2\end{array}$ & $\begin{array}{l}0.11 \\
21.8\end{array}$ & $\begin{array}{l}0.300 \\
0.326\end{array}$ & $\begin{array}{l}0.012 \\
1.441\end{array}$ \\
\hline $\begin{array}{l}\text { BEDN }\left(\mathrm{g} / \mathrm{d} * \mathrm{~kg}^{0.75}\right. \\
\text { BEDN }(\% \text { of fecal N)}\end{array}$ & $\begin{array}{l}0.23^{\mathrm{a}} \\
66.8^{\mathrm{b}}\end{array}$ & $\begin{array}{l}0.29^{\mathrm{b}} \\
52.5^{\mathrm{a}}\end{array}$ & $\begin{array}{c}0.29 \\
65.5^{\mathrm{b}}\end{array}$ & $\begin{array}{c}0.26 \\
59.3^{\mathrm{ab}}\end{array}$ & $\begin{array}{c}0.23 \\
54.2^{\mathrm{a}}\end{array}$ & $\begin{array}{l}0.889 \\
0.562\end{array}$ & $\begin{array}{l}0.012 \\
1.931\end{array}$ \\
\hline BP & $20.9^{b}$ & $11.9^{\mathrm{a}}$ & 18.9 & 16.2 & 14.1 & 0.582 & 1.220 \\
\hline
\end{tabular}

Different superscripts within the same row show significant differences $(\mathrm{p}<0.05)$.

Urine urea and creatinine excretion were significantly reduced when SBP diet was fed. Among the breeds, SH pigs showed the highest amount of urea and CB the highest amount of creatinine in urine (table 8). 
Table 8: Influence of diet and breed on urea and creatinin excretion in urine $\left(\mathrm{g} / \mathrm{d}^{*} \mathrm{~kg}^{0.75}\right)$

\begin{tabular}{|l|c|c|c|c|c|c|c|}
\hline & \multicolumn{2}{|c|}{ Diet } & \multicolumn{3}{c|}{ Breed } & Inter- & SEM \\
& $\begin{array}{c}\text { Basal } \\
(\mathrm{n}=18)\end{array}$ & $\begin{array}{c}\text { SBP } \\
(\mathrm{n}=18)\end{array}$ & $\begin{array}{c}\text { SH } \\
(\mathrm{n}=12)\end{array}$ & $\begin{array}{c}\text { BB } \\
(\mathrm{n}=12)\end{array}$ & $\begin{array}{c}\text { CB } \\
(\mathrm{n}=12)\end{array}$ & action & SEM \\
\hline Urea & $0.94^{\mathrm{b}}$ & $0.69^{\mathrm{a}}$ & $0.92^{\mathrm{b}}$ & $0.82^{\mathrm{ab}}$ & $0.71^{\mathrm{a}}$ & 0.450 & 0.036 \\
Creatinine & 0.091 & 0.088 & $0.080^{\mathrm{a}}$ & $0.087^{\mathrm{a}}$ & $0.102^{\mathrm{b}}$ & 0.645 & 0.003 \\
\hline
\end{tabular}

Different superscripts within the same row show significant differences $(p<0.05)$.

\section{Mineral balances}

The results of mineral balances are shown in table 9. Addition of SBP led to a significant higher intake of all minerals. Considering calcium, there was no significant influence of the diet on fecal excretion and retention, whereas urinary $\mathrm{Ca}$ excretion was significantly lower when SBP diet was fed. The influence of the breed was significant for fecal Ca excretion with lowest proportions for $\mathrm{CB}$ and highest for $\mathrm{SH}$. As urinary $\mathrm{Ca}$ excretion remained unaffected by the breed, Ca retention was highest for $\mathrm{CB}$ and lowest for $\mathrm{SH}$.

Regarding phosphorus, there was a significantly lower urinary $\mathrm{P}$ excretion associated with feeding the SBP diet. SH pigs excreted significantly more P via feces and showed lower P retentions than the other two breeds.

Sodium balance was influenced by diet and breed. BB pigs excreted significantly less sodium via urine than SH pigs. However, retention was not significantly influenced. Considering fecal excretion, there was an interaction between diet and breed observed. When fed on the basal diet $\mathrm{SH}$ and $\mathrm{CB}$ pigs excreted significantly less sodium via feces, whereas SBP diet led to lowest fecal excretion for $\mathrm{SH}$ and highest for CB pigs.

Potassium excretion was significantly affected by the diet, with the proportion of fecal excretion being higher and the proportion of urinary excretion being lower when SBP diet was fed. Additionally, the breed influenced potassium excretion with BB showing significantly lower urine excretion and higher fecal excretion than CB pigs. Retention was neither affected by the breed nor by the diet.

Diet and breed also affected magnesium excretion and retention. The addition of SBP resulted in a lower proportion but higher amount of urinary $\mathrm{Mg}$ excretion, leading to a higher retention due to high intake and unaffected proportional fecal excretion. A significant influence of the breed was only observed for urine excretion, which was lower for CB than for BB pigs.

Mineral digestibility except for sodium and potassium was not influenced by the diet. Sodium digestibility showed an interaction between diet and breed. When basal diet was fed highest sodium digestibility was observed for SH and CB pigs. In contrast to that, feeding SBP diet resulted in higher sodium digestibility for $\mathrm{SH}$ and $\mathrm{BB}$ compared to $\mathrm{CB}$ pigs. 
Table 9: Influence of diet and breed on mineral balances

\begin{tabular}{|c|c|c|c|c|c|c|c|}
\hline & \multicolumn{2}{|c|}{ Diet } & \multicolumn{3}{|c|}{ Breed } & \multirow{2}{*}{$\begin{array}{l}\text { Inter- } \\
\text { action }\end{array}$} & \multirow[b]{2}{*}{ SEM } \\
\hline & $\begin{array}{c}\text { Basal } \\
(n=18)\end{array}$ & $\begin{array}{c}\text { SBP } \\
(n=18) \\
\end{array}$ & $\begin{array}{c}\text { SH } \\
(n=12) \\
\end{array}$ & $\begin{array}{c}\mathbf{B B} \\
(n=12) \\
\end{array}$ & $\begin{array}{c}\mathbf{C B} \\
(\mathrm{n}=12) \\
\end{array}$ & & \\
\hline $\begin{array}{l}\text { Calcium } \\
\text { Intake }\left(\mathrm{mg} / \mathrm{d}^{*} \mathrm{~kg}^{0.75}\right) \\
\text { Feces }(\%) \\
\text { Urine }(\%) \\
\text { Retention }(\%) \\
\text { Digestibility }(\%)\end{array}$ & $\begin{array}{c}637.1^{\mathrm{a}} \\
53.9^{\mathrm{b}} \\
3.4^{\mathrm{b}} \\
42.7 \\
46.1\end{array}$ & $\begin{array}{c}827.5^{b} \\
56.5 \\
2.4^{\mathrm{a}} \\
41.1 \\
43.5\end{array}$ & $\begin{array}{c}736 . .^{\mathrm{c}} \\
60.9^{\mathrm{c}} \\
2.9^{\mathrm{a}} \\
36.3^{\mathrm{a}} \\
39.1^{\mathrm{a}}\end{array}$ & $\begin{array}{c}728.6 \\
55.7^{\mathrm{b}} \\
2.9^{\mathrm{b}} \\
41.4^{\mathrm{b}} \\
44.3^{\mathrm{b}}\end{array}$ & $\begin{array}{c}732.2^{\mathrm{a}} \\
49.1^{\mathrm{a}} \\
2.9^{\mathrm{c}} \\
48.1^{\mathrm{c}} \\
51.0^{\mathrm{b}}\end{array}$ & $\begin{array}{l}0.451 \\
0.504 \\
0.229 \\
0.635 \\
0.504\end{array}$ & $\begin{array}{c}16.197 \\
1.144 \\
0.199 \\
1.129 \\
1.144\end{array}$ \\
\hline $\begin{array}{l}\text { Phosphorus } \\
\text { Intake }\left(\mathrm{mg} / \mathrm{d}^{*} \mathrm{~kg}^{0.75}\right) \\
\text { Feces }(\%) \\
\text { Urine }(\%) \\
\text { Retention }(\%) \\
\text { Digestibility }(\%)\end{array}$ & $\begin{array}{c}388.1^{\mathrm{a}} \\
58.5 \\
0.6^{\mathrm{b}} \\
41.0 \\
41.6\end{array}$ & $\begin{array}{c}399.0^{\mathrm{b}} \\
59.6 \\
0.3^{\mathrm{a}} \\
40.4 \\
40.6\end{array}$ & $\begin{array}{c}395.2 \\
64.1^{\mathrm{b}} \\
0.5 \\
35.4^{\mathrm{a}} \\
35,9^{\mathrm{a}}\end{array}$ & $\begin{array}{c}392.4^{\mathrm{a}} \\
58.5^{\mathrm{a}} \\
0.4^{\mathrm{b}} \\
41.2^{\mathrm{b}} \\
41.5^{\mathrm{b}} \\
\end{array}$ & $\begin{array}{c}393.0 \\
54.1^{\mathrm{a}} \\
0.4^{\mathrm{b}} \\
45.5^{\mathrm{b}} \\
45.9^{\mathrm{b}} \\
\end{array}$ & $\begin{array}{l}0.676 \\
0.904 \\
0.524 \\
0.881 \\
0.904 \\
\end{array}$ & $\begin{array}{l}1.225 \\
1.060 \\
0.051 \\
1.070 \\
1.060 \\
\end{array}$ \\
\hline $\begin{array}{l}\text { Sodium } \\
\text { Intake }\left(\mathrm{mg} / \mathrm{d}^{*} \mathrm{~kg}^{0.75}\right) \\
\text { Feces }(\%) \\
\text { Urine }(\%) \\
\text { Retention }(\%) \\
\text { Digestibility }(\%)\end{array}$ & $\begin{array}{c}112.4^{\mathrm{a}} \\
21.6 \\
24.2 \\
54.2 \\
78.4\end{array}$ & $\begin{array}{c}138.6^{\mathrm{a}} \\
21.6 \\
21.4 \\
57,1 \\
78.4\end{array}$ & $\begin{array}{c}126.0 \\
16.5^{\mathrm{b}} \\
27.1^{\mathrm{b}} \\
56.4 \\
78.9\end{array}$ & $\begin{array}{c}125.1 \\
27.2 \\
17.7^{\mathrm{a}} \\
55.0 \\
72.8\end{array}$ & $\begin{array}{c}123.3 \\
21.1 \\
23.4^{\mathrm{ab}} \\
55.5 \\
83.5\end{array}$ & $\begin{array}{l}0.737 \\
0.010 \\
0.335 \\
0.547 \\
0.010\end{array}$ & $\begin{array}{l}2.228 \\
1.277 \\
1.415 \\
1.108 \\
1.277\end{array}$ \\
\hline $\begin{array}{l}\text { Potassium } \\
\text { Intake }\left(\mathrm{mg} / \mathrm{d}^{*} \mathrm{~kg}^{0.75}\right) \\
\text { Feces }(\%) \\
\text { Urine }(\%) \\
\text { Retention }(\%) \\
\text { Digestibility }(\%)\end{array}$ & $\begin{array}{c}559.3^{\mathrm{a}} \\
18.3^{\mathrm{a}} \\
37.2^{\mathrm{b}} \\
44.5^{\mathrm{b}} \\
81.7^{\mathrm{b}} \\
\end{array}$ & $\begin{array}{c}622.8^{\mathrm{b}} \\
24,5^{\mathrm{b}} \\
28.7^{\mathrm{a}} \\
46.8^{\mathrm{a}} \\
78.5^{\mathrm{a}} \\
\end{array}$ & $\begin{array}{c}595.6 \\
21.3^{\mathrm{ab}} \\
32.1^{\mathrm{ab}} \\
46 . .^{\mathrm{ab}} \\
78.8^{\mathrm{ab}} \\
\end{array}$ & $\begin{array}{c}589.5 \\
17.7^{\mathrm{a}} \\
37.0^{\mathrm{b}} \\
45.3^{\mathrm{b}} \\
82.2^{\mathrm{b}} \\
\end{array}$ & $\begin{array}{c}588.0 \\
25.3^{\mathrm{b}} \\
29.8^{\mathrm{a}} \\
44.9^{\mathrm{a}} \\
74.7^{\mathrm{a}} \\
\end{array}$ & $\begin{array}{l}0.723 \\
0.090 \\
0.525 \\
0.412 \\
0.090 \\
\end{array}$ & $\begin{array}{l}5.549 \\
1.026 \\
1.389 \\
1.002 \\
1.026 \\
\end{array}$ \\
\hline $\begin{array}{l}\text { Magnesium } \\
\text { Intake }\left(\mathrm{mg} / \mathrm{d}^{*} \mathrm{~kg}^{0.75}\right) \\
\text { Feces }(\%) \\
\text { Urine }(\%) \\
\text { Retention }(\%) \\
\text { Digestibility }(\%)\end{array}$ & $\begin{array}{c}123.9^{\mathrm{a}} \\
73.8 \\
8.4^{\mathrm{b}} \\
17.8^{\mathrm{a}} \\
26.2\end{array}$ & $\begin{array}{c}184,3^{\mathrm{b}} \\
73.7^{\mathrm{a}} \\
7.0^{\mathrm{a}} \\
19.3^{\mathrm{b}} \\
26.3\end{array}$ & $\begin{array}{c}154.9 \\
73.5 \\
8.2^{\mathrm{ab}} \\
18.2 \\
25.6\end{array}$ & $\begin{array}{c}153.4 \\
74.4 \\
8.6^{\mathrm{b}} \\
17.0 \\
26.5\end{array}$ & $\begin{array}{c}154.0 \\
73.4 \\
6.2^{\mathrm{a}} \\
20.4 \\
26.6\end{array}$ & $\begin{array}{l}0.514 \\
0.987 \\
0.415 \\
0.896 \\
0.987\end{array}$ & $\begin{array}{l}5.117 \\
0.725 \\
0.398 \\
0.745 \\
0.725\end{array}$ \\
\hline
\end{tabular}

Different superscripts within the same row show significant differences $(p<0.05)$.

\section{Discussion}

The aim of this study was to investigate the influence of adding fiber-rich sugar beet pulp on digestive processes in different pig breeds. There have been many studies on the influence of different types of fiber on digestive processes in pigs; however, the effect in different pig breeds has not been investigated so far. SBP was chosen as the fiber rich addition because of its high content of total NSP and high amount of dietary fiber (NSP+Lignin) (BACH KNUDSEN, 1997).

Both experimental diets consisted of the same basal diet. Basal diet was calculated to meet $100 \%$ of protein and amino acid and $80 \%$ of the energy requirement of a growing pig in the particular weight range. Lysine, methionine and threonine were added to assure meeting an ideal amino acid profile (RoTH et al., 1993; WANG \& FULLER, 1989). This assures that energy 
gained from intestinal fiber fermentation in the hindgut of the pigs fed the additional SBP could be used for protein retention and other energy-dependent pathways.

Due to feeding the same basal diet to all pigs, differences occurring in the digestive patterns between the two diets should be attributed to the effect of SBP addition.

The addition of SBP led to a significantly higher WHC. This is in agreement with other experiments, which confirm a higher WHC and, as a result of that, higher digesta viscosity when fiber rich feedstuff especially with high soluble NSP content was fed (JOHANSEN \& Bach KnUdSen, 1994; JohAnSEN et al., 1996; MiQuel et al., 2001). These authors ascertained a higher bulking capacity and influences on digesta passage rates through the gastro intestinal tract as caused by elevated WHC of fiber rich feed, which could last for several hours after feeding. While WHC of NSP rich feedstuff had no effect or even prolonged passage rate in stomach and small intestine, passage time in the large intestine was shortened under the presence of fiber (DROCHNER, 1984; KESTLING et al., 1991; JOHANSEN et al., 1996).

The formation of a water layer between mucosa and digesta and inhibition of gut motility are the most important influences on digestive processes caused by the WHC of soluble NSP, such as SBP (EDWARDS, 1990; FLOURIÉ, 1992; FURDA, 1990).

In all cases, except for crude fiber, the addition of NSP by SBP led to a significantly reduced digestibility. This is in agreement with other observations been made when pigs were fed different kinds of NSP rich feedstuff (BACH KNUDSEN et al., 1991, 1993a; BAKKER et al., 1998; Drochner, 1984; GALIBOIS et al., 1994; SCHRAMA et al., 1998).

Highest influence of fiber addition on nutrient digestibility was observed for protein and fat. The negative effect of NSP on protein and fat digestibility can be caused in different ways. Apparent digestibility could be affected by an increased secretion of digestive juices in the case of protein (BOISEN \& FERNÁNDES 1995; LETERME et al., 2000) and increased amount of bile acids or changes in bile acid composition in the case of fat (FURDA, 1990; JOHNSON, 1992; Madar \& Odes, 1990; Mosenthin \& Sauer, 1993; SchneEman, 1990; Story et al, 1990) as well as by an increased microbial synthesis of protein and fat (KREUZER et al., 1991; LE GOFF et al., 2001; MrOZ et al., 2000). One factor could be a reduced true digestibility by decreased nutrient digestion and absorption as a result of high water binding capacity, changes in nutrient flow (BACH KNUDSEN et al., 1993a,b; JOHANSEN et al., 1996) and by the specific physical-chemical properties of the fiber, as in the case of glycoproteins, which tend 
to build complexes between each other as well as with cellulosemicrofibrills and thus reduce enzyme-substrate contact (GRALA et al., 1999).

$\mathrm{N}$-Balances, which show higher portions of fecal $\mathrm{N}$ when pigs were fed on the fiber-rich diet, are in accordance with the above-mentioned processes. They are also indicating a trend for higher $\mathrm{N}$ excretion via feces and a lower urine $\mathrm{N}$ excretion when SBP diet was fed. Higher fecal $\mathrm{N}$ excretion, as a result of fiber rich feeding, was also observed in experiments done by Kreuzer et al. (1999), Le Goff et al. (2000), Mroz et al. (2000) and Zervas\& ZiJLstra (2003). Considering the present experiment, partitioning of fecal N-excretion showed, that this is a result of increased amounts of UDN, WSN and BEDN when feeding the SBP diet. The amount of UDN was likely increased by the increased amount of fiber-bound nitrogen in the SBP diet. Increased WSN and BEDN are a result of increased secretion of digestive juices and an increased microbial synthesis with feeding the SBP diet. Some investigations (BAKKER et al., 1996; BeAmes \& EgGuM, 1981; Bergner \& TegtMeier, 1985; Mosenthin et al., $1992 \mathrm{a}, \mathrm{b})$ were able to show that nitrogen required for microbial synthesis of protein in the intestine of pigs was secreted from the blood into the large intestine. This would lead to a reduced urinary $\mathrm{N}$-excretion and especially to a reduced urea concentration in the urine as observed in the present study. The amount of BP per 100g BFS, which may be considered as a measure of the apparent efficiency of bacterial protein synthesis, was nearly halved with the SBP diet. This might indicate that rapidly fermentable carbohydrates present in SBP would lead to a lack of substrate before excretion thereby reducing the BP excretion by previous autolysis and degradation of the bacteria (DROCHNER \& MEYER, 1991).

The elevated N-retention in pigs fed on the SBP diet is a result of utilizing the fiber of the sugar beet pulp by microbes. Their fermentation products in the form of SCFA can be used as an extra energy source for protein deposition in the animal. This was also found by LENIS et al. (1996), where the addition of purified wheat bran NDF reduced the ileal digestion of nitrogen but increased the utilization of of digested nitrogen of about $8 \%$. Furthermore, Nretention may have been increased by higher microbial $\mathrm{N}$-fixation as well by higher endogenous protein deposition in the intestinal tract of the pigs.

Degradation of crude fiber, NDF and ADF was significantly increased in pigs fed the SBP diet. This might be based on the type of fiber and was also observed in a similar experiment carried out by KREUZER et al. (1999). Whereas fiber of the basal diet was mostly derived from cereal hulls with high content of insoluble NSP, fiber of the SBP-diet consisted of hulls from cereals plus easily digestible fiber from the sugar beet pulp. 
The breed did not significantly influence digestibility, except for NDF and crude fiber. This is in accordance with the hypothesis, that different pig breeds may differ in their ability for fiber degradation. However, there is no clear indication for higher fiber degradation in old local pig breeds. SH pigs showed lowest fiber digestibility, while this was higher for BB and CB pigs. This might be the result of different intestinal capacities and therefore modified transit time through the intestinal tract. A shorter small intestine could result in lower precaecal fiber digestibility. Lower precaecal digestibility might also be the result of less digestive juices which would be supported by the low content of water soluble fecal N. The WSN-fraction, which includes endogenous nitrogen from digestive juices was lower in pigs fed no SBP and showed a tendency to be lower in SH compared to BB and CB pigs. A less pronounced precaecal fiber degradability would result in higher amounts of fiber reaching the caecum and colon of pigs. As a result of that, BEDN fraction and amount of bacterial protein per $100 \mathrm{~g}$ BFS are higher in SH pigs. However, this fact does not mean that microbial activity is very efficient. It could also be an indication of still higher amounts of fermentable substrate in the colon and feces of these pigs. Furthermore, high urinary N excretion of SH pigs, containing high urea and low creatinine proportions, indicate, that digested $\mathrm{N}$ was not retained, neither by intestinal microbes nor by tissues of the animal.

This was very different for CB pigs. High fiber digestibility, high amounts of water-soluble $\mathrm{N}$ and lower proportions of NDF and ADF in caecum content are indicative of efficient precaecal fiber digestion. Thus, a lack of fermentable substrate in the caecum and colon of pigs, together with bacterial suppressing properties of digestive juices and bile acids lead to significantly lower portions of bacterial nitrogen in feces (DROCHNER \& MEYER, 1991; DEMEYER \& DE GRAEVE, 1991).

BB pigs showed the highest level of crude fiber and along with CB pigs had the highest NDF digestion, even though fiber composition in caecum content probably resembled that of SH pigs. WSN tended to be lower and BEDN to be higher in CB pigs. This indicates different contributions of precaecal and postileal digestion between these two breeds. Lower amounts of BP per 100g BFS in CB and BB compared to SH pigs, may be explained by reduced fermentable substrate at the end of the colon and in feces leading to stimulated microbial autolysis.

SBP mostly consists of soluble NSP, which are already partially degradable in the small intestine of pigs (BACH KNUDSEN et al., 1991, 1993; BACH KNUDSEN \& CANIBE, 2000; BACH Knudsen \& Hansen, 1991; CAnibe \& Bach Knudsen, 2001, Shi \& Noblet, 1993a, b). This seems to have occurred to differing extents in the three pig breeds used for this study. The 
potential of various pig breeds for the digestion of lower degradable fiber should be probed in further studies. Maybe, the BB pig with more pronounced hindgut fermentation would then be superior as compared to the CB pigs, which showed (at least in this experiment) a high tendency to precaecal digestion of soluble fiber.

In vitro experiments have shown mineral-binding and complex-binding capabilities of fiber and fiber associated substances (FrøLICH, 1990; ROSSANDER et al., 1992), which could lead to a reduced mineral absorption in the intestine of pigs fed fiber-rich feedstuff. In the present study feeding a fiber-rich diet resulted in a lower crude ash digestibility, lower potassium digestibility and a trend to lower calcium digestibility. A reduced ash digestibility is in accordance with results achieved by BAKKER et al. (1998). Influences on the digestibility of other minerals like phosphorus, sodium and magnesium as observed by BAKKER et al. (1998) and DROCHNER (1984) could not be confirmed in this study.

The influence of fiber addition on mineral balances mostly depends on the type and the amount of fiber (BAKKER et al., 1998; DROCHNER, 1984; GALIBOIS et al., 1994; JONGBLOED \& MROZ, 1997; KROYER et al., 1995).

Differences in mineral metabolism can be caused by changes in $\mathrm{pH}$ values, which are more pronounced for soluble than for insoluble fiber (CAMERON et al., 2000; FRøLICH, 1990). Thus, SBP diet with high soluble NSP content may have modified the intestine $\mathrm{pH}$ values. It is suggested, that the observed differences in mineral metabolism among the experimental diets and pig breeds are caused by the associative effects of fiber on mineral binding and precaecal/postileal digestive processes.

\section{References}

Bach Knudsen, K.E.; Jensen, B.B.; Andersen, J.O.; Hansen, I, 1991. Gastrointestinal implications in pigs of wheat and oat fractions. 2. Microbial activity in the gastrointestinal tract. British Journal of Nutrition 65, 233-248

Bach Knudsen, K.E.; Jensen, B.B.; HAnsen, I.,1993a. Oat bran but not a ß-Glucan-enriched oat fraction enhances butyrate production in the large intestine of pigs. Journal of Nutrition, 1235-1247

Bach KnUdsen, K.E.; Jensen, B.B.; HAnsen, I., 1993b. Digestion of polysaccharides and other major components in the small intestine of pigs fed on diets consisting of oat fractions rich in B-D-Glucan. British Journal of Nutrition 70, 537-556

BACH KnUdSEn, K.E., 1997. Carbohydrate and lignin contents of plant material used in animal feeding. Animal Feed Science and Technology 67, 319-338 
BACH KNUdSEN, K.E. \& CANIBE, N., 2000. Breakdown of plant carbohydrates. Journal of the Science of Food and Agriculture 80, 1252-1261

Bach KNUdSEN, K.E.\& HAnsen, I., 1991. Gastrointestinal implications in pigs of wheat and oat fractions. 1. Digestibility and bulking properties of polysaccharides and other major constituents. British Journal of Nutrition 65, 217-232

BAKKer, G.C.M.; BaKker, J.G.M.; DeKker, R.A.; Everts, H.; Jongbloed, VAn Der MEULEN, J.; LENIS, N.P., 1996. The quantitative relationship between absorption of nitrogen and starch from the hindgut of pigs. Journal of Animal Sciences 74, 188A

BAKKer, G.C.M; DekKer, R.A.; Jongbloed, R.; Jongbloed, A.W., 1998. Non-starch polysaccharides in pig feeding. Veterinary-Quarterly. 20 (3), 59-64

BeAmes, R.M. \& EGGuM, B.O., 1981. The effect of type and level of protein, fibre and starch on nitrogen excretion patterns in rats. British Journal of Nutrition 46, 301-313

Bergner, H. \& TegtMeier, B., 1985. Beziehungen zwischen der ${ }^{15} \mathrm{~N}$-Exkretion über den Kot nach oraler ${ }^{15} \mathrm{~N}$-Harnstoffaufnahme und der Blutharnstoffkonzentration in Abhängigkeit von der Rohfaseraufnahme bei Schweinen. Archiv für Tierernährung 35 (8), 535-543

Boisen, S. \& FERnÁndeS, J.A., 1995. Prediction of the apparent ileal digestibility of protein and amino-acids in feedstuffs and feed mixtures for pigs by in vitro analyses. Animal Feed Science and Technology 51, 29-43

CAmeron, I.L.; Hardman, W.E.; Heitman, D.W.; CARTer, J.W., 2000. Dietary fibre on cell proliferation in large bowel mucosal crypts near or away from lymphoid nodules and on mineral bioavailability. Cell proliferation 33(6), 367-379

Canibe, N. \& Bach Knudsen, K.E., 2001. Degradation and physicochemical changes of barley and pea fibre along the gastrointestinal tract of pigs. Journal of the Science of Food and Agriculture 82, 27-39

De LANGe, C.F.M.; Souffrant, W.B.; SAUER, W.C., 1990. Real ileal protein and amino acid digestibilities in feedstuffs for growing pigs as determined with the ${ }^{15} \mathrm{~N}$-Isotope dilution technique. Journal of Animal Science 68, 409-418

Demeyer, D.I \& De Graeve, K., 1991. Differences in stoichiometry between rumen and hindgut fermentation, Journal of Animal Physiology and Animal Nutrition 22, 50-61

DLG/2002. Leistungs- und qualitätsgerechte Schweinefütterung. Teil A: Mastschweine. DLG-Information 1/2002, Frankfurt am Main

DrochNeR, W., 1984. Einfluß wechselnder Rohfaser und Pektingehalte im Futter auf präcaecale und postileale Verdauungsvorgänge beim wachsenden Schwein. Fortschritte in der Tierphysiologie und Tierernährung 14, Verlag Paul Parey, Hamburg, Berlin 
DrochneR, W. \& MEYeR, H., 1991. Verdauung organischer Substanzen im Dickdarm verschiedener Haustierarten. Journal of Animal Physiology and Animal Nutrition, Suppl. 22, 18-40

EDWARDS, C., 1990. Mechanisms of action of dietary fibre on small intestine adsorption and motility. In: FURDA, I. \& BRINE, C.J. (Eds.), New developments in dietary fibre: physiological, physiochemical and analytical aspects. Advances in experimental medicine and biology, Vol.270, Plenum Press, New York, London

FLOURIÉ, B., 1992. Influence of dietary fibre on carbohydrate digestion and adsorption. In: SchweIZER, T.F. \& EdWARDS, C.A. (Eds.), Dietary fibre: A component of food: Nutritional function in health and desease., ILSI Human Nutrition Reviews, SpringerVerlag, London, 181-196

FrøLiCH, W., 1990. Chelating properties of dietary fiber and phytate. The role for mineral availability. In: FURDA, I. \& BRINE, C.J. (Eds.), New developments in dietary fibre: physiological, physiochemical and analytical aspects. Advances in experimental medicine and biology, Vol. 270, Plenum Press, New York, London

FURDA, J., 1990. Interaction of dietary fibre with lipids-mechanistic theories and their limitations. In: FURDA, I. \& BRINE, C.J. (Eds.), New developments in dietary fibre: physiological, physiochemical and analytical aspects. Advances in experimental medicine and biology, Vol.270, Plenum Press, New York, London, 67-82

Galibois, I.; Desrosiers, T.; Guevin, N.; Lavigne, C.; JaQues, H., 1994. Effects of dietary fibre mixtures on glucose and lipid metabolism and on mineral adsorption in the rat. Annals of Nutrition and Metabolism 38 (4), 203-211

Goering, H.K. \& VAN Soest, P.J., 1970. Forage fiber analysis. Apparatus, reagents, procedures and some applications. Agricult. Handbook No. 379, Agricultural Research Service, Dep. of documents, US Government Printing off., Washington, DC, 20 pages

Grala, W.; Verstegen, M.W.A.; Jansman, A.J.M.; Huisman, J., Van Leeuwen, P., 1999. Apparent protein digestibility and recovery of endogenous nitrogen at the terminal ileum of pigs fed diets containing various soyabean products, peas or rapeseed hulls. Animal Feed Science and Technology 80, 231-245

JohANSEN, H.N. \& BACH KNUDSEN, K.E., 1994. Effects of wheat flour and oat mill fractions of jejunal flow, starch degradation and adsorption of glucose over an insulated loop of jejunum in pigs. British journal of Nutrition 72, 299-313

Johansen, H. N.; Bach Knudsen, K.E.; Sandström, B.; SkJøth, F., 1996. Effects of varying content of soluble dietary fibre from wheat flour and oat milling fractions on gastric emptying in pigs. British Journal of Nutrition. 75, 339-351

JoHnSON, I.T., 1992. The influence of dietary fibre on lipid digestion and adsorption. In: SchweIZER, T.F. \& EdWARDS, C.A. (Eds.), Dietary fibre: A component of food: Nutritional function in health and desease. ILSI Human Nutrition Reviews, SpringerVerlag, London, 167-180 
JongBloed, A.W. \& Mroz, Z., 1997. Intestinal adsorption and secretion of minerals along the digestive tract of pigs. In: Laplace, J.P.; FÉVrier, C.; BarbeAU, A. (Eds.), Digestive physiology in pigs. INRA, Paris, France, 288-299

Kestling, U.; Schnabel, E.; Bolduan, G., 1991. Zur Dickdarmkapazität der Sau. In: KirChGessner, M. (Ed.), Verdauungsphysiologie des Dickdarms. Fortschritte in der Tierphysiologie und Tierernährung 22, Verlag Paul Parey, Hamburg, Berlin, 84-88

KreuZer, M.; Roth, F.X.; KirChgesSner, M., 1989. Mikrobielle Umsetzungen im Enddarm von Sauen bei intracaecaler Infusion hoher Mengen an reinen Substraten. 1. Veränderungen der Verdaulichkeit von Stickstoff und Aminosäuren. Landwirtschaftliche Forschung 42, 72-92

KreUZER, M.; KIRCHGESSNER, M.; RoTH, F.X., 1991. Experimental evaluation of the capacity of the hindgut of sows to ferment purified dietary ingredients and of consequences in nitrogen metabolism. In: KIRCHGESSNER, M. (Ed.), Verdauungsphysiologie des Dickdarms. Fortschritte in der Tierphysiologie und Tierernährung 22, Verlag Paul Parey, Hamburg, Berlin, 62-66

Kreuzer, M.; Wittmann, A.; Gerdemann, M.M.; Henneken, H.; Abel H.J.; MACHMÜLLER, A., 1999. Re-examination of the metabolizable energy contents of various rations containing different types and levels of bacterially fermentable substrates in digestibility experiments with growing pigs. Journal of Animal Physiology and Animal Nutrition 82, 33-49

KroYer, G.T.; HAMmerschmidt, V.; WASHÜTtL, J., 1995. Bioavailability of mineral substances and trace elements in the presence of dietary fibre. Deutsche Lebensmittel Rundschau 91 (9), 289-291

Le Goff, G. \& Noblet, J., 2001. Comparative tract digestibility of dietary energy and nutrients in growing pigs and adult sows. Journal of Animal Science 79, 2418-2427

Lenis, N.P.; BikKer, P.; VAN DER Meulen, J.; VAn DiePen, J.T.; BAKKeR, J.G.; JongBloed, A.W., 1996. Effect of dietary neutral detergent fiber on ileal digestibility and portal flux of nitrogen and amino acids and on nitrogen utilization in growing pigs. Journal of Animal Science 74 (11), 2687-2699

Leterme, P.; Souffrant, W.-B.; THÉWIS, A., 2000. Effect of barley fibres and barley intake on the endogenous nitrogen losses in piglets. Journal of Cereal Science 31, 229-239

LoftField, N. \& Beese, F., 1999. $\mathrm{HNO}_{3}$ Druckaufschlüsse: Eine brauchbare Methode zur ökochemischen Charakterisierung von Böden. unpublished

LOw, A.G., 1990. Nutritional regulation of gastric secretion, digestion and emptying. Nutritional Research Reviews 3, 229-252

MACHMÜLLER, A., 1994. Einfluß erhöhter Gehalte an bakteriell fermentierbarer Substanz in der ration wachsender Schweine auf den N-Umsatz in Tier, Gülle, Boden und Pflanze sowie auf die Mastleistung und die Qualität von Schlachtkörper und Fleisch, Dissertation, Universität Göttingen 
MADAR, Z. \& ODES, H.S., 1990. Dietary fibre research. Progress in Biochemical Pharmacology Vol. 24, Karger Verlag

MASON, V.C., 1969. Some preliminary observations on the distribution and origin of nitrogen in sheep faeces. Journal of agricultural sciences 73, 99-111

MiQuel, N.; BACH KNUdSEN, K.E.; JøRGEnSEN, H., 2001. Impacts of diets varying in dietary fibre characteristics on gastric emptying in pregnant sows. Archiv Tierernährung, 121145

Mosenthin, R.; Sauer, W.C.; De Lange, C.F.M, 1992. Tracer studies of urea kinetics in growing pigs: The effect of intravenous infusion of urea on urea recycling and the site of urea secretion into the Gastrointestinal tract. Journal of Animal Science 70, 34583466

Mosenthin, R.; Sauer, W.C.; Henkel, H.; Ahrens, F.; De Lange, C.F.M, 1992. Tracer studies of urea kinetics in growing pigs: The effect of starch infusion at the distal ileum on urea recycling and bacterial nitrogen excretion. Journal of Animal Science $70,3467-3472$

Mosenthin, R. \& SAUER, W.C., 1993. Exocrine pancreatic secretions in pigs as influenced by the source of carbohydrate in the diet. Zeitschrift für Ernährungswissenschaft $32(2), 152-155$

Mroz, Z.; Moeser, A.J.; Vreman, K.; Van DiePen, J.T.; Van Kempen, T.; Canh, T.T.; JONGBLOED, A.W., 2000. Effects of dietary carbohydrates and buffering capacity on nutrient digestibility and manure characteristics in finishing pigs. Journal of Animal Science 78, 3096-3106

NAUMANN, C.\& BASSLER, R., 1976-1997. Die chemische Untersuchung von Futtermitteln, Methodenbuch, volume 3 with supplements 1983, 1988 and 1993, loose-leave collection. Darmstadt, VDLUFA-Verlag

Potkins, Z.V. LAWrence, T.L.J.;ThOMLinson, J.R., 1991. Effects of structural and nonstructural polysaccharides in the diet of growing pigs on gastric emptying rate and rate of passage of digesta to the terminal ileum and through the total gastrointestinal tract. British Journal of Nutrition 65, 391-413

Rossander, L.; SAndBerg, A.-S.; SAndSTRÖM, B., 1992. The influence of dietary fibre on mineral adsorption and utilization. In: SCHWEIZER, T.F. \& EDWARDS, C.A. (Eds.), Dietary fibre: A component of food: Nutritional function in health and desease. ILSI Human Nutrition Reviews. Springer-Verlag, London, 197-216

Roth, F.X.; MARKert, W.; KirChgessner, M., 1993. Zur optimalen Versorgung mit $\alpha-$ Aminostickstoff von Mastschweinen. 2. Mitteilung über Bilanzstudien zur Reduzierung der N-Ausscheidung. Journal of Animal Physiology and Animal Nutrition. 70, 196-206 
SCHNEEMAN, B.O., 1990. Gastrointestinal responses to dietary fiber. In: FURDA, I. \& BRINE, C.J. (Eds.), New developments in dietary fibre: physiological, physiochemical and analytical aspects. Advances in experimental medicine and biology, Vol.270, Plenum Press, New York, London, 37-42

Schrama, J.W., Bosch, M.W.; Verstegen, M.W.A.; VorselaArs, A.H.P.M.; HaAKsma, J; HeETKAMP, M.J.W., 1998. The energetic value of nonstarch polysaccharides in relation to physical activity in group-housed growing pigs. Journal of Animal Sciences $76,3016-3023$

ShI, X. S. \& Noblet, J., 1993a. Digestible and metabolizable energy values of ten feed ingredients in growing pigs fed ad libitum and sows fed at maintenance level; comparative contribution of the hindgut. Animal Feed Science and Technology 42, 223-236

SHI, X. S. \& NoBlet, J., 1993b. Contribution of the hindgut to digestion of diets in growing pigs and adult sows; effect of diet composition. Livestock Production Science 34, 237235

Story, J.A.; WAtTerson, J.J.; MAtheson, H.B.; Furumoto, E.J., 1990. Dietary fiber and bile acid metabolism. In: FURDA, I. \& BRINE, C.J. (Eds.), New developments in dietary fibre: physiological, physiochemical and analytical aspects. Advances in experimental medicine and biology, Vol.270, Plenum Press, New York, London

WANG, T.C. \& Fuller, M.F., 1989. The optimum dietary amino acid pattern for growing pigs. British Journal of Nutrition 62, 77-89

ZERVAS, S. \& ZIJLSTRA, R.-T., 2003. Effects of dietary protein and fermentable fiber on nitrogen excretion patterns and plasma urea in growing pigs. Journal of Animal Science 80 (12), 3247-56 


\title{
Study 3
}

\section{Influence of sugar beet pulp addition on fermentation characteristics in different pig breeds using the Colon Simulation Technique (COSITEC).}

\begin{abstract}
In a 2 factorial experiment three different breeds; Schwäbisch Hällisches Schwein (SH), Buntes Bentheimer Schwein (BB) and crossbreed pigs (CB), each with 12 animals and two diets differing in BFS content (basal diet (B) and basal diet + sugar beet pulp (SBP)) were tested on their capacity for hindgut fermentation. Basal diet was calculated to meet $80 \%$ of energy and $100 \%$ of N-requirement. This was in order to give pigs that were fed the SBP diet the opportunity to use energy from fiber for N-retention. Pigs had an average weight of $37.9 \pm$ $5.3 \mathrm{~kg}$ and were used in a metabolic trial at first. After the trial, the pigs were slaughtered and their caecum and colon content used for in vitro fermentation with the colon simulation technique (COSITEC). Degradability of OS, NDF and ADF increased with feeding the SBPdiet. Diet and breed interacted in the case of DM and ash degradability. The highest degradation for CB pigs was analyzed when fed on the basal diet and for BB pigs on the SBP diet. Total SCFA production increased with feeding the SBP diet. Acetate, butyrate and propionate production showed an interaction between diet and breed. Acetate production was highest for SH pigs when fed on the basal diet and highest for BB when fed the SBP-diet. The amount of $\mathrm{CO}_{2}, \mathrm{CH}_{4}$ and $\mathrm{H}_{2}$ also increased with feeding the SBP diet compared to the basal diet.
\end{abstract}

\section{Introduction}

Due to a lack of endogenous enzymes, pigs cannot digest non-starch-polysaccharides (NSP). Therefore these feed components need to be fermented by intestinal microbes. Fermentation products are short chain fatty acids (SCFA), fermentation gases and fermentation heat. The fermentation of NSP with the associated conversion into SCFA is the only possibility for the animal to gain energy from these substances, with absorbed SCFA principally showing lower biochemical efficiency than glucose (RÉMÉSY et al., 1992; SHI \& NOBLET, 1993a, b).

Sufficient supplies of fermentable substrate and nitrogen for microbial synthesis are important prerequisites of microbial activity. The amount and composition of SCFA and gases are dependent on type and composition of fermentable substrate being offered with the feed (BACH KNUdSEN et al., 1991, 2000; BACH KNUdSEN \& CANIBE, 2000; BolduAN et al., 1991; 
Christensen et al., 1999; Freire et al., 2000; JENSEN \& Jørgensen, 1994; JørGenSEN et al., 2001; RIJINEN et al., 2001) and may also be influenced by the pig breed.

As a consequent selection based on high daily body weight gains and high feed utilization when feeding concentrated feedstuff may have led to morphological changes in the digestive tract. This may also affect the substrate-dependent fermentation characteristics in the hindgut of modern crossbreed pigs as compared to old local breeds.

The aim of this experiment was to study the influence of feeding a sugar beet pulp supplement to different pig breeds on fermentation characteristics, expressed by fiber degradation, amount and composition of SCFA as well as by the amount and composition of fermentation gases during in vitro fermentation by using the Colon Simulation Technique (DREYER, 1990).

\section{Material and methods}

\section{Animals and feeding}

Three different breeds, two local breeds "Buntes Bentheimer Schwein" (BB), "Schwäbisch Hällisches Schwein" (SH) and a modern crossbreed pig (CB: (Landrace x Large White) x Pietrain)) with 12 animals each (3 repetitions with 4 animals), were used for the experiment. After having been used for a metabolic trial (study 2), the pigs were slaughtered after overnight fasting.

Pigs received two different diets. The easily digestible basal diet consisted of wheat, barley, soybean meal, potato protein, soybean oil and a mineral premix (table 1). Synthetic amino acids were added to assure fulfillment of protein and amino acid requirements. The SBP diet consisted of basal diet plus 20\% sugar beet pulp. Fiber contents, BFS and ME content of both diets are shown in table 2 .

Table 1: Components of the experimental diets (\%)

\begin{tabular}{|l|c|c|}
\hline \multicolumn{1}{|c|}{ Components } & Basal diet & SBP-diet \\
\hline Wheat & 40.00 & 32.00 \\
Barley & 29.75 & 23.80 \\
Soy bean meal & 20.00 & 16.00 \\
Potato protein & 5.00 & 4.00 \\
Premix Vilomin & 3.00 & 2.40 \\
Soy bean oil & 2.00 & 1.60 \\
L-Lysine HCl & 0.17 & 0.136 \\
DL-Methionine & 0.06 & 0.048 \\
L-Threonine & 0.02 & 0.016 \\
Sugar beet pulp & & 20.00 \\
\hline
\end{tabular}

Per kg Premix: 24\% Ca, 5\% P, 5\% Na, 1\% Mg, Additives: 400000 I.U. Vit.A, 40000 I.U. Vit.D3, 2000mg Vit.E, $500 \mathrm{mg} \mathrm{Cu}$ 
Table 2: DM content (\%) and ingredients (\%DM) of the experimental diets

\begin{tabular}{|l|c|c|}
\hline \multicolumn{1}{|c|}{ Ingredients } & Basal diet & SBP-diet \\
\hline Dry matter & 88.63 & 88.52 \\
Organic matter & 95.13 & 94.52 \\
Ash & 4.87 & 5.48 \\
Crude protein & 24.13 & 21.13 \\
Ether extract & 3.88 & 3.26 \\
Crude fiber & 3.25 & 5.83 \\
N-free extract & 63.87 & 64.30 \\
Starch & 43.99 & 35.88 \\
Sugar & 4.23 & 5.99 \\
NDF & 13.29 & 18.60 \\
ADF & 4.48 & 7.94 \\
\hline BFS & 11.69 & 19.64 \\
ME [MJ/kg DM] & 15.46 & 13.99 \\
\hline
\end{tabular}

\section{The COSITEC System}

The Cositec system is a colon simulation model, which is originated in the technique developed by CZERKAWSKI \& BECKENRIDGE (1977) for rumen simulation (RUSITEC) and modified for semi-continuous colon simulation by DREYER (1990).

COSITEC is a semi-continuous in vitro flow system also permitting qualitative and quantitative study of metabolic characteristics of intestinal microbes and thus also permits conclusions on in vivo conditions.

To begin the system, the caecum content of the slaughtered pigs was taken and separated into a liquid and solid phase by means of sterile gauze. Ten grams of solid phase per fermentor were filled in a nylon bag. This bag, together with a second one containing $2.2 \mathrm{~g}$ of freezedried caecum content of the pigs, was inserted into the perforated inner container. The container then was placed in the pre-warmed fermentor, which then was filled up with the liquid phase of the caecum content to the upper border to give a volume of $125 \mathrm{ml}$. The fermentation vessels were locked gastight, arrested in the water bath and the guiding rod was fixed on the stroke rod. After fixing buffer and overflow tubes, pumps and electric motors were started. The fermentor was continually supplied with buffer (table 3) at a rate of $625 \mathrm{ml} / \mathrm{d}$. Then fermentation vessels were flushed with nitrogen to generate anaerobic conditions. Overflow collecting flasks were placed in ice-filled styrofoam boxes to suppress microbial activity. 
Table 3: Composition of artificial buffer (mmol/l)

\begin{tabular}{|c|c|}
\hline Chemicals & Concentration \\
\hline $\mathrm{NaCl}$ & 115.0 \\
\hline $\mathrm{KCl}$ & 10.0 \\
\hline $\mathrm{MgCl}_{2} 6 \mathrm{H}_{2} \mathrm{O}$ & 2.5 \\
\hline $\mathrm{CaCl}_{2} 2 \mathrm{H}_{2} \mathrm{O}$ & 2.5 \\
\hline $\mathrm{NaOH}$ & 0.2 \\
\hline $\mathrm{NaH}_{2} \mathrm{PO}_{4} \mathrm{H}_{2} \mathrm{O}$ & 2.0 \\
\hline $\mathrm{Na}_{2} \mathrm{SO}_{4}$ & 1.0 \\
\hline $\mathrm{NaHCO}_{3}$ & 25.0 \\
\hline $\mathrm{NH}_{4} \mathrm{Cl}$ & 5.0 \\
\hline
\end{tabular}

Every 24 hours the system was interrupted for a brief time. The fermentation vessel was opened and the $\mathrm{pH}$-value and redox potential measured. The nylon bag with the digesta content was removed and replaced by another one containing freeze-dried caecum content. The removed bag was squeezed twice for two minutes in prewarmed artificial buffer and the liquid poured back into the fermentor. The residue in the bag was collected for analyses.

The overflow flask was completely emptied and samples for analyses taken. Gasbags were fixed at the beginning of the collection period and removed at the end.

The experiment time was divided into a five-day equilibration and a five-day collection period.

\section{Analyses}

Weende Analysis

Ash and crude fiber of the COSITEC substrate, consisting of dried caecum content and the solid residue in the bag were analyzed according to the Weende analysis (NAUMANN \& BASSLER, 1976).

NDF and ADF were determined in an ANKOM Fiber Analyzer according to the method of GOERING\& VAN SOEST (1970).

Starch and sugar

Starch content in the diet was determined polarmetrically according to the Verbandsmethode of VDLUFA (NAUMANN \& BASSLER, 1976). Sugar content was determined according to the method of Luff- Schorl (NAUMANN \& BASSLER, 1976).

Determination of $\mathrm{pH}$-value and redox potential

The determination of $\mathrm{pH}$ value was carried out once daily before changing the feedbags by means of a pH electrode (Digital pH Meter 646, KNICK, Berlin; measuring section Type 408, METTLER-TOLEDO, Steinbach). 
Measurement of the redox potential also took place before changing the nylon bags using a redox electrode. (Digital pH Meter 646, KNICK, Berlin; measuring section Type Bt 4805/120 METTLER-TOLEDO, Steinbach).

\section{Measurement of fermentation gases}

Determination of the gas volume was carried out by means of a $2000 \mathrm{ml}$ polyethylene measuring cylinder with a three-way valve on its bottom. In order to gain the gas quantitatively, this valve was connected to the gasbags via a gastight tube. After being totally submerged in a water tank the gas was sucked out of the gasbag by the water suction pressure by pulling out the cylinder, which was held with the bottom up. The volume of the vacuumed gas could be read off directly from the scale of the cylinder.

The gas volume in mol can be calculated by modifying the general gas equation $(\mathrm{p} * \mathrm{~V}=\mathrm{n} * \mathrm{R} * \mathrm{~T})$ :

$$
\mathrm{n}(\mathrm{mol})=\frac{p^{*} v}{R * T}\left[\frac{P a^{*} m^{3}}{{ }^{\circ} K}\right]
$$

Gas composition was analyzed gaschromatographically on packed Porapak Q-columns (80/100) with a Shimadzu GC 8A (Shimadzu Europe, Duisburg, Germany). The detector was a thermal conductance detector (TCD). Injection port and detector temperature was $80^{\circ} \mathrm{C}$ and column temperature was $40^{\circ} \mathrm{C}$. Argon was used as carrier gas.

\section{Determination of SCFA}

For the determination of SCFA $5 \mathrm{ml}$ of the overflow were collected daily in glass flasks. Flasks were closed with screw lids and stored frozen at $-20^{\circ} \mathrm{C}$ until analysis.

Before determining SCFA, the samples were thawed in the refrigerator. Samples were centrifuged at $40000 \mathrm{~g}$ at $4{ }^{\circ} \mathrm{C}$ and $0.1 \mathrm{ml}$ of $98 \%$ propionic acid added to $1 \mathrm{ml}$ of the centrifuged sample. The mixture was centrifuged again for 10min at 4000g (Sorvall RC-5C, Du Pont Instruments, Bad Homburg). The decanted liquid was used for analysis. SCFA were analyzed gaschromatographically (HP, Gaschromatograph 5890 II, Böblingen). Analyses were carried out on a self-packed glass column (length $1.8 \mathrm{~m}$; inner diameter $2 \mathrm{~mm}$ ). Chromosorb WAW 80/100 mesh with 20\% Neopentyl-Glycol-Succinat (NPGS) and 2\% ortho-phosphoric acid (Analyt, Müllheim) was used. For determination of SCFA a FID was used as filling material. The composition of the external standard for SCFA determination is shown in table 4 . The temperature of injection port was $220^{\circ} \mathrm{C}$, detector temperature was $250^{\circ} \mathrm{C}$ and column temperature was $120^{\circ} \mathrm{C}$ (isothermal). 
Table 4: External standard for analysis of short chain fatty acids

\begin{tabular}{l|c} 
Acid & $\mathbf{~ m m o l} / \mathbf{l}$ \\
\hline Acetate & 30 \\
Propionate & 8 \\
Iso-Butyrate & 2 \\
Butyrate & 8 \\
Iso-Valerate & 2 \\
Valerate & 2 \\
\hline
\end{tabular}

Molar portions of acetate, propionate, butyrate, iso-valerate and valerate were calculated on the basis of the ratio of the respective fatty acid to total SCFA concentration. Concentration of the individual fatty acids and the daily amount of overflow (ca. $450 \mathrm{ml} / \mathrm{d}$ ) was used to calculate daily SCFA production rate.

\section{Statistical analyses}

Data were analyzed by the analysis of variance using SPSS 10.0. Data were analyzed as block randomized. Diet and breed were considered as factors.

If $F$ values in the analysis of variance were significant, mean values were analyzed with the Tukey multi comparison test. If there were interactions between diet and breed, each, breed and diet were tested individually by analysis of variance.

\section{Results}

\section{Balances and disappearance of dry matter, ash, organic substance and fiber}

All fermentors received the same amount of $2.2 \mathrm{~g}$ DM digesta substrate per day. The composition of these substrates was different between diets and pig breed, which resulted in different inputs of DM, Ash, OM, NDF and ADF as shown in tables 5 and 6. 
Table 5: Influence of diet and pig breed on input, disappeared nutrients and nutrient disappearance rate in the COSITEC

\begin{tabular}{|c|c|c|c|c|c|c|c|}
\hline & \multicolumn{2}{|c|}{ Diet } & \multicolumn{3}{|c|}{ Breed } & \multirow[b]{2}{*}{$\begin{array}{l}\text { Inter- } \\
\text { action }\end{array}$} & \multirow[b]{2}{*}{ SEM } \\
\hline & $\begin{array}{l}\text { Basal } \\
(\mathrm{n}=9)\end{array}$ & $\begin{array}{l}\text { SBP } \\
(\mathrm{n}=9)\end{array}$ & $\begin{array}{c}\text { SH } \\
(n=6)\end{array}$ & $\begin{array}{c}\text { BB } \\
(n=6)\end{array}$ & $\begin{array}{c}\text { CB } \\
(n=6)\end{array}$ & & \\
\hline Input (g/d) & & & & & & & \\
\hline $\mathrm{DM}$ & 2.20 & 2.20 & 2.20 & 2.20 & 2.20 & 0.684 & 0.001 \\
\hline Ash & 0.15 & 0.18 & 0.16 & 0.16 & 0.18 & 0.000 & 0.004 \\
\hline $\mathrm{OM}$ & 2.05 & 2.02 & 2.05 & 2.04 & 2.02 & 0.000 & 0.004 \\
\hline NDF & 1.32 & 1.34 & 1.34 & 1.35 & 1.30 & 0.000 & 0.008 \\
\hline $\mathrm{ADF}$ & 0.64 & 0.84 & 0.74 & 0.75 & 0,73 & 0.000 & 0.024 \\
\hline $\begin{array}{l}\text { Disappeared } \\
(\mathrm{g} / \mathrm{d})\end{array}$ & & & & & & & \\
\hline DM & 0.81 & 0.93 & 0,80 & 0.92 & 0.89 & 0.041 & 0.027 \\
\hline Ash & $0.06^{\mathrm{a}}$ & $0.08^{\mathrm{b}}$ & $0.05^{\mathrm{a}}$ & $0.08^{b}$ & $0.07^{b}$ & 0.076 & 0.024 \\
\hline $\mathrm{OM}$ & 0.75 & 0.85 & 0.75 & 0.84 & 0.81 & 0.001 & 0.005 \\
\hline NDF & $0.25^{\mathrm{a}}$ & $0.40^{\mathrm{b}}$ & 0.30 & 0.36 & 0.32 & 0.076 & 0.023 \\
\hline $\mathrm{ADF}$ & $0.06^{\mathrm{a}}$ & $0.22^{\mathrm{b}}$ & 0.10 & 0.16 & 0.14 & 0.223 & 0.023 \\
\hline $\begin{array}{l}\text { Disappearance } \\
\text { rate }(\%)\end{array}$ & & & & & & & \\
\hline $\mathrm{DM}$ & 37.02 & 42.14 & 36.60 & 41.81 & 40.33 & 0.040 & 1.248 \\
\hline Ash & 38.75 & 41.76 & 33.10 & 46.71 & 40.95 & 0.011 & 2.147 \\
\hline $\mathrm{OM}$ & $36.86^{\mathrm{a}}$ & $42.10^{\mathrm{b}}$ & 36.73 & 41.43 & 40.28 & 0.060 & 1.223 \\
\hline NDF & $19.25^{\mathrm{a}}$ & $29.76^{\mathrm{b}}$ & 22.39 & 26.41 & 24.72 & 0.083 & 1.691 \\
\hline $\mathrm{ADF}$ & $8.97^{\mathrm{a}}$ & $25.75^{b}$ & 13.40 & 20.79 & 17.90 & 0.189 & 2.572 \\
\hline
\end{tabular}

Different superscripts within the same row show significant differences $(p<0.05)$.

As table 5 shows, there were some influences of diet and breed on grams of disappeared nutrients per day and disappearance rate of nutrients in the COSITEC fermentor. In the case of dry matter there was an interaction between breed and diet, showing that if basal diet was fed, SH had the lowest and CB the highest amount of disappeared DM per day and highest disappearance. If SBP diet was fed the highest amount of disappeared DM and the highest disappearance was observed for BB but was not significant. Differences in disappeared DM (g/d) and disappearance in the same breed between the two diets were observed for SH (significantly) and BB (not significant), but not for CB (table 6).

There was also an interaction observed considering ash disappearance. When basal diet was fed SH showed the lowest and CB the highest disappearance rate, whereas when SBP diet was fed the highest disappearance was found for $\mathrm{BB}$. There was also a trend for $\mathrm{SH}$ and $\mathrm{BB}$ having an elevated ash disappearance and for $\mathrm{CB}$ having a decreased ash disappearance rate when using SBP diet.

Disappearance rate of organic substance was only significantly influenced by the diet, but there was a tendency indicating a lower disappearance for SH pigs. In contrast, the amount of disappeared OM per day showed an interaction of diet and breed. If basal diet was fed, the highest amount of disappeared OM was found in the CB fermentors, whereas a tendency to a higher amount of disappeared OM per day was observed for BB. 
NDF and ADF degradability were significantly higher for the fermentors that received digesta substrate from SBP diet fed pigs, but were not significantly influenced by the breed. However, as for OM there was also a trend showing lowest degradability when SH pigs were used.

Table 6: Influence of diet and breed on input, disappeared nutrients and nutrient disappearance in the COSITEC; differentiation of interaction cases

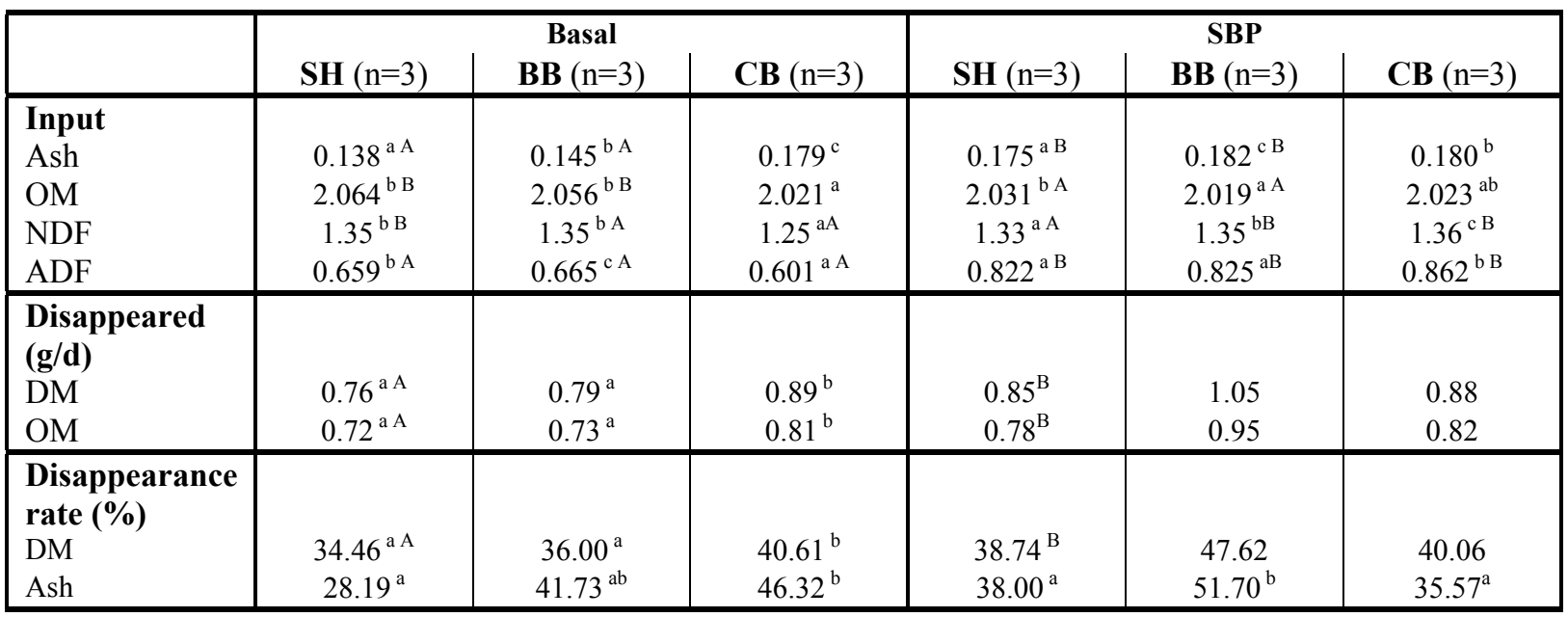

Different superscript letters show significant differences between breeds within the diet (small letters) or between diets for the same breed (capital letters), $(p<0.05)$.

\section{Production of SCFA}

Breed and diet significantly influenced the amount of SCFA produced per day. Both factors interacted with each other for all three analyzed fatty acids, as shown in table 7.

Table 7: Influence of diet and pig breed on SCFA production in the COSITEC: differentiation of the interaction cases $(\mathrm{mmol} / \mathrm{d})$

\begin{tabular}{|c|c|c|c|c|c|c|}
\hline & \multicolumn{3}{|c|}{ Basal } & \multicolumn{3}{|c|}{ SBP } \\
\hline & $\mathbf{S H}(n=3)$ & BB $(n=3)$ & $\mathbf{C B}(\mathrm{n}=3)$ & $\mathbf{S H}(n=3)$ & $\mathbf{B B}(n=3)$ & $\mathbf{C B}(n=3)$ \\
\hline Acetate & $3.47^{\mathrm{bA}}$ & $3.14^{\mathrm{aA}}$ & $3.23^{\mathrm{aA}}$ & $4.13^{\mathrm{aB}}$ & $4.97^{\mathrm{bB}}$ & $3.68^{\mathrm{aB}}$ \\
\hline Propionate & $1.84^{\mathrm{bA}}$ & $1.69^{\mathrm{aA}}$ & $2.02^{\mathrm{c}}$ & $2.09^{\mathrm{abB}}$ & $2.23^{\mathrm{bB}}$ & $1.90^{\mathrm{a}}$ \\
\hline Butyrate & $0.57^{\mathrm{abB}}$ & $0.60^{\mathrm{bA}}$ & $0.53^{\mathrm{a}}$ & $0.48^{\mathrm{aA}}$ & $0.68^{\mathrm{bB}}$ & $0.49^{\mathrm{a}}$ \\
\hline
\end{tabular}

Different superscript letters show significant differences between breeds within diets (small letters) or between diets for the same breed (capital letters), ( $\mathrm{p}<0.05)$.

Acetate production was lower in fermentors with basal diet as feed compared to those, in which SBP was used. Within the fermentors, which were supplied with basal diet substrate, highest acetate production per day was observed for SH pigs with $3.47 \mathrm{mmol} / \mathrm{d}$ compared to 3.14 and $3.23 \mathrm{mmol} / \mathrm{d}$ for $\mathrm{BB}$ and $\mathrm{CB}$ pigs respectively. In contrast to that, $\mathrm{BB}$ pigs produced the highest amount of acetate $(4.97 \mathrm{mmol} / \mathrm{d})$ when SBP-diet was fed, while the production rate of $\mathrm{SH}$ and $\mathrm{CB}$ pig fermentors were significantly lower.

Propionate production was also higher in fermentors being fed with SBP substrate of SH and BB pigs. As already shown for acetate there was no indication that one breed produced more 
propionate than the other breeds due to the interaction of breed and diet. If basal diet was given, $\mathrm{CB}$ pigs showed the highest $(2.02 \mathrm{mmol} / \mathrm{d})$ and $\mathrm{BB}$ the lowest propionate production $(1.69 \mathrm{mmol} / \mathrm{d})$, but if high fiber SBP diet was fed, CB pigs showed the lowest $(1.92 \mathrm{mmol} / \mathrm{d})$ and $\mathrm{BB}$ pigs the highest amount of propionate.

There was no clear trend for butyrate production depending on the substrate being used. In the cases of SH and CB pigs SBP led to a reduced butyrate production from 0.57 to $0.48 \mathrm{mmol} / \mathrm{d}$ (significant) and from 0.53 to $0.49 \mathrm{mmol} / \mathrm{d}$ (significantly) respectively, whereas butyrate production for $\mathrm{BB}$ pigs increased significantly from 0.60 to $0.68 \mathrm{mmol} / \mathrm{d}$. However, independent which diet was fed butyrate production was highest for BB pigs and lower for the other ones.

\section{pH value and redox potential}

Similarly as for SCFA, the $\mathrm{pH}$ values for breed and diet interacted with each other. A differentiation of the interaction showed that feeding the high fiber diet resulted in reduced $\mathrm{pH}$ values for $\mathrm{BB}$ (from 6.63 to 6.44 ) and $\mathrm{SH}$ (from 6.59 to 6.46 ) compared to feeding the basal diet, whereas $\mathrm{pH}$ was not significantly influenced by diet considering $\mathrm{CB}$ pigs (from 6.57 to 6.62$)$.

Redox potential was significantly influenced by diet and breed but did not show any interaction. Feeding the SBP diet resulted with $-154.13 \mathrm{mV}$ in significantly stronger reducing conditions compared to feeding the basal diet that showed a redox potential of $-103.96 \mathrm{mV}$. Considering the breed, redox potential was highest for BB pigs $(-120.83 \mathrm{mV})$ and differed significantly from the redox potential observed for the other two breeds (SH: -135.87 and $\mathrm{CB}$ : $-130.43)$.

\section{Production of fermentation gases}

Diet and breed influenced the production of fermentation gases during COSITEC (table 8) but did not show any interaction. The influence of the diet on gas production was significant for $\mathrm{CO}_{2}$. The amount of the gases $\mathrm{CO}_{2}, \mathrm{CH}_{4}$ and $\mathrm{H}_{2}$ was elevated when the high fiber SBP diet was fed.

Table 8: Influence of diet and pig breed on the production of fermentation gases (mmol/d) during COSITEC

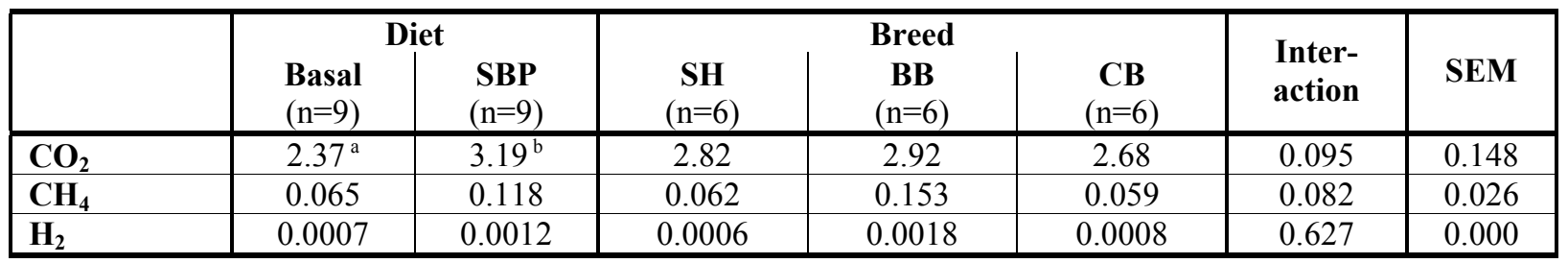

Different superscripts within the same row show significant differences $(\mathrm{p}<0.05)$. 
Differences among the three breeds being used were not significant. There was a trend showing a higher molar production of $\mathrm{CO}_{2}, \mathrm{CH}_{4}$ and $\mathrm{H}_{2}$ and a higher portion of $\mathrm{CO}_{2}$ and $\mathrm{CH}_{4}$ of total gas amount for BB.

\section{Hydrogen Balances}

Hydrogen balances (table 9 and 10) were calculated from $\mathrm{SCFA}, \mathrm{CH}_{4}$ and $\mathrm{H}_{2}$ produced during COSITEC. Considering the production, consumption and balance, there was an interaction between the two factors. Interaction cases are shown in table 10. The hydrogen recovery was influenced by diet and breed. The addition of SBP led to a reduced hydrogen recovery compared to the basal diet. The lowest recovery among the breeds was found for SH pigs while the highest was for CB pigs.

Table 9: Influence of diet and pig breed on hydrogen balances

\begin{tabular}{|c|c|c|c|c|c|c|c|}
\hline & \multicolumn{2}{|c|}{ Diet } & \multicolumn{3}{|c|}{ Breed } & \multirow{2}{*}{$\begin{array}{l}\text { Inter- } \\
\text { action }\end{array}$} & \multirow{2}{*}{ SEM } \\
\hline & $\begin{array}{l}\text { Basal } \\
(n=9)\end{array}$ & $\begin{array}{c}\text { SBP } \\
(\mathrm{n}=9)\end{array}$ & $\underset{(n=6)}{\text { SH }}$ & $\begin{array}{c}\text { BB } \\
(n=6)\end{array}$ & $\begin{array}{c}\text { CB } \\
(\mathrm{n}=6)\end{array}$ & & \\
\hline $\mathrm{H}_{2}$ production & 10.69 & 12.80 & 11.68 & 12.64 & 10.91 & 0.007 & 0.413 \\
\hline $\mathrm{H}_{2}$ consumption & 5.07 & 5.73 & 5.20 & 5.82 & 5.18 & 0.014 & 0.205 \\
\hline Balance & 5.62 & 7.08 & 6.48 & 6.82 & 5.74 & 0.008 & 0.237 \\
\hline $\begin{array}{l}\text { Recovery (\%) } \\
\text { (Prod. / Cons.) }\end{array}$ & $47.45^{b}$ & $44.54^{\mathrm{a}}$ & $44.55^{\mathrm{a}}$ & $45.92^{\mathrm{ab}}$ & $47.52^{b}$ & 0.056 & 0.656 \\
\hline
\end{tabular}

Different superscript letters within the same row show significant differences $(\mathrm{p}<0.05)$.

Table 10: Influences of diet and pig breed on hydrogen balances: differentiation of the interaction cases

\begin{tabular}{|l|c|c|c|c|c|c|}
\hline & \multicolumn{3}{|c|}{ Basal } & \multicolumn{3}{c|}{ SBP } \\
& $\mathbf{S H}(\mathrm{n}=3)$ & $\mathbf{B B}(\mathrm{n}=3)$ & $\mathbf{C B}(\mathrm{n}=3)$ & $\mathbf{S H}(\mathrm{n}=3)$ & $\mathbf{B B}(\mathrm{n}=3)$ & $\mathbf{C B}(\mathrm{n}=3)$ \\
\hline $\mathbf{H}_{2}$ production & $11.07^{\mathrm{A}}$ & $10.39^{\mathrm{A}}$ & $10.60^{\mathrm{A}}$ & $12.28^{\mathrm{a}} \mathbf{B}$ & $14.89^{\mathrm{b}^{\mathbf{B}}}$ & $11.23^{\mathrm{a}} \mathbf{B}$ \\
$\mathbf{H}_{2}$ consumption & 5.06 & 4.79 & $5.36^{\mathbf{B}}$ & 5.34 & 6.85 & $5.00^{\mathrm{A}}$ \\
Balance & $6.02^{\mathrm{A}}$ & $5.60^{\mathrm{A}}$ & $5.24^{\mathrm{A}}$ & $6.95^{\mathrm{a}}$ & $8.04^{\mathrm{b}}$ & $6.24^{\mathbf{B}^{\mathbf{B}}}$ \\
\hline
\end{tabular}

Different superscript letters show significant differences between breeds within diet (small letters) or between diets for the same breed (capital letters), $(\mathrm{p}<0.05)$.

\section{Discussion}

The aim of this study was to investigate the influence of adding fiber rich sugar beet pulp on the fermentation characteristics in the hindgut of different pig breeds.

The COSITEC system was supplied with caecum content of pigs fed either the basal diet or the basal diet plus SBP supplement, thus enabling a study of the impact of the additional fiber rich feeding on postileal digesta degradation and microbial activity.

Disappearance of the organic substance, NDF and ADF was lower in the fermentors, which received substrate of caecum content from pigs fed the basal diet. This can be explained by 
the type of fiber, which was degraded to a different extent prior to reaching the caecum and colon. Fiber of basal diet consisted mostly of cereal hulls with a high content of insoluble NSP, whereas fiber of the SBP diet additionally consisted of easily digestible fiber.

The trend of higher disappearance rates for OS, NDF and ADF for the digesta of BB pigs points to differences in the type of bacterial fermentation. Digesta substrate of SH pigs showed even lower fiber disappearance than that of CB pigs.

Fermentative fiber degradation is associated with the production of SCFA, fermentation gases and fermentation-heat by intestinal microbes. Feeding SBP resulted in an elevated production of total SCFA in COSITEC. Thus $\mathrm{pH}$ values did decrease when SBP diet was fed, except for CB pigs. Higher fiber-stimulated SCFA production in the caecum and colon of pigs has repeatedly been determined in vivo or in vitro (BACH KNUDSEN et al., 1993; BACH KNUDSEN \& CANIBE, 2000; BACH KNUDSEN et al., 2000; BOLDUAN et al., 1991; CHRISTENSEN et al. 1999). Depending on the type of fiber being used in the diet, the elevation of SCFA production was more or less pronounced. BACH KNUDSEN \& CANIBE (2000) and BOLDUAN et al. (1991) observed, that SCFA production was more elevated with a diet consisting of soluble NSP as is present in SBP or oat bran as compared to a diet containing insoluble NSP. As SCFA can be used as an extra energy source, not only the amount of SCFA produced is of importance, but also the amount of SCFA being absorbed in the hindgut of pigs. BACH KNUDSEN et al. (2000) reported, that an elevated content of fermentable fiber in the diet significantly increased the net absorption of SCFA compared to diets containing less NSP.

In the present investigation, acetate and propionate production were pronouncedly elevated when digesta substrate of SBP-fed pigs was supplied to COSITEC. This is in agreement with other authors (BACH KNUDSEN et al., 1991, 2000; BACH KNUDSEN \& CANIBE, 2000; BOLDUAN et al., 1991; FREIRE et al., 2000) who observed, that depending on which type of fiber was used in the diet, either the acetate or propionate or butyrate production was increased.

Higher amounts of SCFA caused by elevated microbial activity in the fermentors supplied with digesta substrate of pigs fed SBP corresponded to values observed for gas production. Gas production was elevated for all three gases $\mathrm{CH}_{4}, \mathrm{CO}_{2}$ and $\mathrm{H}_{2}$. JENSEN \& JøRGENSEN (1994) and JøRGENSEN et al., (1996) also observed increasing portions of microbial $\mathrm{CH}_{4}, \mathrm{CO}_{2}$ and $\mathrm{H}_{2}$ with increasing fiber content. LE GOFF et al. (2002) RAMONET et al. (2000) and RIJINEN et al. (2001) reported that energy losses by methane are in linear relation to fiber intake. On the assumption that one gram of dietary fiber contains an energy content of $18.1 \mathrm{~kJ}$ LE GOFF \& NOBLET (2001), LE GOFF et al. (2002), NOBLET \& LE GOFF (2001) and RiJiNEN 
et al. (2001) a loss of energy through methane production of about 3-7\% per gram of digestible crude fiber can be calculated. Energy losses through hydrogen production, which can be about $40 \%$ of that caused by methane (JENSEN \& JØRGENSEN, 1994) are not confirmed by the present study.

Not only the diet but also the pig breed significantly affected microbial activity. Even though not significant, fiber disappearance of digesta substrate from SH pigs tended toward lower values than that of $\mathrm{CB}$ and $\mathrm{BB}$ pigs in particular. The increased DM disappearance observed for $\mathrm{SH}$ and $\mathrm{BB}$ substrates after feeding the SBP diet, which tendencially corresponded with fiber disappearance rates, must be attributed to lower precaecal digestibilities as compared to CB pigs. Feeding the SBP diet led to significantly higher production of SCFA with substrate from $\mathrm{BB}$ pigs and tended toward higher values for SH pigs as compared to those for CB pigs. Production of $\mathrm{CH}_{4}, \mathrm{CO}_{2}$ and $\mathrm{H}_{2}$ was highest, although not significantly so, for BB pigs. These data cannot merely be explained as the result of fiber fermentation per se during the Cositec trial, but it also points to different precaecal fiber digestion processes and thus different caecum content among the breeds.

Differences in the fermentation type among the three breeds are also confirmed by the $\mathrm{pH}$ values and redox potentials. Whereas feeding the high-fiber diet resulted in reduced $\mathrm{pH}$ values for $\mathrm{BB}$ and $\mathrm{SH}$ pigs when compared to feeding the basal diet, the $\mathrm{pH}$ value for $\mathrm{CB}$ breed remained virtually unaffected by the fiber addition. Redox potential was significantly influenced by breed and diet but did not show an interaction between both factors. Differences in the redox potential between the diets and breeds can be explained by differences in fatty acid production, not only of those determined in the present study and, by different contents of proteins and amino acids including those of microbes, also not determined in this study.

The low hydrogen recoveries observed for all treatments are indicative of reductive acetogenesis (DE Graeve et al., 1994; DemeYer \& De Graeve, 1991; Durand \& BERNALIER, 1993). The lower hydrogen recovery rate with the SBP diet when comparing SH pigs to $\mathrm{CB}$ pigs showed an obviously positive correlation of this pathway to the higher substrate fermentability under this experiment's conditions. The reductive pathway, in which carbon dioxide is reduced to acetate under the presence of special microorganisms, was more pronounced in both older pig breeds. Since these microorganisms need low $\mathrm{pH}$ values, this could be an explanation for the observed differences. But differences in the fermentable substrate as described earlier may also be the reason.

All observations made for SCFA, fermentation gases, $\mathrm{pH}$ values, redox potentials and the process of reductive acetogenesis confirm that intestinal fiber fermentation varies between 
different genetic origins of pigs. The main reason for such differences must be attributed to genetically modified adaptive responses in intestinal morphophysiology. Additional studies are necessary to elucidate the conditions and potentials of microbial digestion in different breeds of pigs.

\section{References}

Bach Knudsen, K.E.; Jensen, B.B.; Andersen, J.O.; Hansen, I, 1991. Gastrointestinal implications in pigs of wheat and oat fractions. 2. Microbial activity in the gastrointestinal tract. British Journal of Nutrition 65, 233-248

Bach Knudsen, K.E.; Jensen, B.B.; HAnsen, I., 1993. Oat bran but not a ß-Glucan-enriched oat fraction enhances butyrate production in the large intestine of pigs. Journal of Nutrition, 1235-1247

BACH KnUdsen, K.E. \& CANiBE, N., 2000. Breakdown of plant carbohydrates. Journal of the Science of Food and Agriculture 80, 1261

Bach Knudsen, K.E.; Jørgensen, H.; CAniBe, N., 2000. Quantification of the adsorption of nutrients derived from carbohydrate assimilation: model experiment with pigs fed wheat or oat based rolls. British Journal of Nutrition 84 (4), 449-458

Bolduan, G.; SchnABel, E.; BeCK, M., 1991. Fermentierungseffekte in Dickdarmabschnitten beim Schwein. In: KIRCHGESSNER, M. (Ed.), Verdauungsphysiologie des Dickdarms. Fortschritte in der Tierphysiologie und Tierernährung 22, Paul Parey Verlag, Hamburg, Berlin, 80-83

Christensen, D.N.; BACH KNUdSen, K.E.; WolstruP, J.; Jensen, B.B., 1999. Integration of ileum cannulated pigs and in vitro fermentation to quantify the effect of diet composition on the amount of short-chain fatty acids available from fermentation in the large intestine. Journal of the Science of Food and Agriculture 79, 755-762

Czerkawski, J.W. \& BeCKenRIDGe, G., 1977. Design and development of long-term rumen simulation technique (Rusitec). British Journal of Nutrition 38, 371-384

De Graeve, K.G.; Grivet, J.P.; Durand, M., Beaumatin, P., Cordelet, C.; Hannequart, G.; DEMEYER, D., 1994. Competition between reductive acetogenesis and methanogenesis in the pig large-intestinal flora. Journal of Applied Bacteriology 76, $55-61$

DeMEYER, D.I. \& DE GRAEVE, K., 1991. Differences in stoichiometry between rumen and hindgut fermentation. Advances in Animal Physiology and Animal Nutrition 22, 5061

DurAnd, M. \& Bernalier, A., 1993. Reductive acetogenesis in animal and human gut. In Cummings, J.H.; Rombeau, J.L.; SAKata (Eds.) Physiological and clinical aspects of short chain fatty acid metabolism., Cambridge University Press 
DREYER, J., 1990. In- vitro Untersuchungen mit der Colon-Simulations-Technik (Cositec) zum mikrobiellen Stoffwechsel im Dickdarm von Schweinen, Dissertation, Universität Göttingen

Freire, J.P.B.; Guerreiro, A.J.G.; CunHA, L.F.; Aumaitre, A., 2000. Effect of dietary fibre source on total tract digestibility, caecum volatile fatty acids and digestive transit time in the weaned piglet. Animal Feed Science and Technology 87, 71-83

Goering, H.K. \& VAN Soest, P.J., 1970. Forage fiber analysis. Apparatus, reagents, procedures and some applications. Agricult. Handbook No. 379, Agricultural Research Service, Dep. of documents, US Government Printing off., Washington, DC, 20 pages

JENSEN, B.B. \& JøRGENSEN, H., 1994. Effect of dietary fibre on microbial activity and microbial gas production. Applied and Environmental Microbiology 60, 1897-1904

JØrgensen, H.; ZhaO, X.-Q.; EgGuM, B., 1996. The influence of dietary fibre and environmental temperature on the development on the gastrointestinal tract, digestibility, degree of fermentation in the hindgut and energy metabolism in pigs. British Journal of Nutrition 75, 365-378

Jørgensen, H.; Bach Knudsen, K.E.; Jørgensen, H., 2001. Effect of dietary fibre on energy metabolism of growing pigs and pregnant sows. In: CHWALIBOG, A.; JAKOBSEN, K. (Eds.) Energy metabolism in animals. EAAP publication 103 (Wageningen press), 105-108

Le Goff, G.; Le Groumellec, L.; Van Milgen, J.; Dubois, S.; Noblet, J., 2002. Digestibility and metabolic utilization of dietary energy in adult sows. Influence of addition and origin of dietary fibre. British Journal of Nutrition 87, 325-335

Le Goff, G. \& Noblet, J., 2001. Comparative tract digestibility of dietary energy and nutrients in growing pigs and adult sows. Journal of Animal Science 79, 2418-2427

NAumann, C. \& BASSleR, R., 1976-1997. Die chemische Untersuchung von Futtermitteln, Methodenbuch, volume 3 with supplements 1983, 1988 and 1993, loose-leave collection. Darmstadt, VDLUFA-Verlag

Noblet, J. \& Le Goff, G., 2001. Effect of dietary fibre on energy value of feeds for pigs. Animal Feed Science and Technology 90, 35-52

Ramonet, Y.; Van Milgen, J.; Dourmad, J.Y.; Meunier-SAlaün, M.C.; Noblet, J., 2000. The effect of dietary fibre on energy utilisation and partitioning of heat production over pregnancy in sows. British Journal of Nutrition 84, 85-94

RÉMÉSY, C.; DEMIGNÉ, C.; MorAnD, C., 1992. Metabolism and utilisation of short chain fatty acids produced by colonic fermentation. In: SCHWEIZER, T.F. \& EDWARDS, C.A. (Eds.), Dietary fibre: A component of food: Nutritional function in health and desease. ILSI Human Nutrition Reviews. Springer-Verlag, London, 137-150

RIJINEN, M.M.J.A, 2001. Effect of dietary fermentable carbohydrates on energy metabolism in group housed pigs. Journal of Animal Science 79, 148-154 
ShI, X.S. \& Noblet, J., 1993a. Digestible and metabolizable energy values of ten feed ingredients in growing pigs fed ad libitum and sows fed at maintenance level; comparative contribution of the hindgut. Animal Feed Science and Technology 42, 223-236

SHI, X.S. \& NoBlet, J., 1993b. Contribution of the hindgut to digestion of diets in growing pigs and adult sows; effect of diet composition. Livestock Production Science 34, 237235 


\title{
Study 4
}

\section{The use of microcalorimetry to determine microbial activity in caecum content of pigs fed diets differing in bacterially fermentable substrate content.}

\begin{abstract}
Microbial heat production was used as a measure for microbial metabolism in the intestine content of pigs. In a two-factorial experiment, the influence of two diets differing in bacterially fermentable substrate (BFS) content and three different breeds on the microbial activity in the caecum content of slaughtered pigs was tested using a microcalorimeter with closed ampules under anaerobic conditions. The basal diet (B) and the basal diet + sugar beet pulp (SBP) were fed to three different breeds; Schwäbisch Hallisches Schwein (SH), Buntes Bentheimer Schwein (BB) and crossbreed pig (CB), each with 12 animals. The heat output curves showed high values at the beginning of the experiment and decreased to an almost constant value with time. Heat production was increased with the SBP-diet and was highest for SH pigs, followed by BB pigs and lowest for CB pigs, indicating influences of diet and breed on microbial activity in the caecum of pigs.
\end{abstract}

\section{Introduction}

Since there is a relationship between microbial activity and heat production, microcalorimetry is considered to be a suitable method in fields were microbial activity is of importance. Experiments in soil sciences showed that it was already successfully used to determine microbial biomass (AlBERS et al., 1995; SPARLING, 1981, 1983; RAUBUCH \& BEESE, 1999) or to analyze microbial activity (BARJA \& NúÑEZ, 1999, TEELING\& CYPIONKA, 1997; VoR et al., 2002). Microcalorimetry is especially useful when studying the process of microbial activity since it permits continuous monitoring of the activity of a living system in situ without disturbing it. Furthermore it allows measurement of microbial growth and activity under anaerobic conditions. Despite these advantages this method has not widely been used by now and there are only few data concerning microbial activity of soils and no experiments using microcalorimetry in animal digestive physiology to determine microbial activity in the intestinal tract of animals. 
The aim of the present study was to investigate the influence of diets with different contents of bacterially fermentable substance (BFS) and of different pig breeds on microbial activity in the caecum by means of microcalorimetry.

\section{Material and methods}

\section{Animals and feeding}

Three different pig breeds, two local breeds "Buntes Bentheimer Schwein" (BB), "Schwäbisch Hällisches Schwein” (SH) and a modern crossbreed pig (CB: (Landrace x Large White) x Pietrain)) with 12 animals each were fed two different diets (table 1 and 2) for a period of 21 days.

The basal diet consisted of easy digestible components and was supplemented with synthetic amino acids to meet protein and amino acid requirements of the pigs. A second diet was composed of the basal diet plus $20 \%$ sugar beet pulp (SBP). The daily amount of feed was divided into two equal portions. Referred to the pig weight and average daily body weight gain, as ascertained in a 7-day adaptation period, basal diet was fed $0.076 \mathrm{~kg}$ and SBP-diet $0.095 \mathrm{~kg} / \mathrm{kg}$ metabolic body weight and day. The animals had free access to water and were slaughtered at the end of the feeding period.

Table 1: Components of the experimental diets (\%)

\begin{tabular}{|l|c|c|}
\hline & Basal diet & SBP diet \\
\hline Wheat & 40.00 & 32.00 \\
Barley & 29.75 & 23.80 \\
Soy bean meal & 20.00 & 16.00 \\
Potato protein & 5.00 & 4.00 \\
Premix & 3.00 & 2.40 \\
Soy bean oil & 2.00 & 1.60 \\
L-LysineHCl & 0.17 & 0.136 \\
DL-Methionine & 0.06 & 0.048 \\
L-Threonine & 0.02 & 0.016 \\
Sugar beet pulp & & 20.00 \\
\hline
\end{tabular}

Per kg Premix: 24\% Ca, 5\% P, 5\% Na, 1\% Mg, Additives: 400000 I.U. Vit.A, 40000 I.U. Vit.D3, 2000mg Vit.E, $500 \mathrm{mg} \mathrm{Cu}$ 
Table 2: DM content (\%) and ingredients (\% DM) of experimental diets

\begin{tabular}{|l|c|c|}
\hline & Basal diet & SBP diet \\
\hline Dry matter & 88.63 & 88.52 \\
Organic matter & 95.13 & 94.52 \\
Ash & 4.87 & 5.48 \\
Crude protein & 24.13 & 21.13 \\
Ether extract & 3.88 & 3.26 \\
Crude fiber & 3.25 & 5.83 \\
N-free extract & 63.87 & 64.30 \\
Starch & 43.99 & 35.88 \\
Sugar & 4.23 & 5.99 \\
NDF & 13.29 & 18.60 \\
ADF & 4.48 & 7.94 \\
ADL & 2.56 & 3.03 \\
Cellulose & 1.92 & 4.91 \\
Hemicellulose & 8.81 & 10.66 \\
\hline BFS & 11.69 & 19.64 \\
ME [MJ/kg DM] & 15.46 & 13.99 \\
\hline
\end{tabular}

\section{Caecum samples}

Samples were taken immediately after slaughtering the pigs. Caecum content was stored in gastight glasses poured with nitrogen before and after being filled with the digesta, in order to preserve anoxic conditions. Samples were stored at $6^{\circ} \mathrm{C}$ since it was assumed that microbial activity of gut bacteria would be reduced to a minimum at this temperature. Caecum material was filled in microcalorimeter ampoules under anoxic conditions, which were assured by using a nitrogen-poured glove box.

\section{Microcalorimetry}

Heat output was measured using a four-channel microcalorimeter of the heat conduction type (thermal activity monitor 2277; thermometric, Järvalla, Sweden). Each of the four channels was equipped with a $25 \mathrm{ml}$ stainless steel ampule, which was filled with $1 \mathrm{~g}$ fresh caecum content and closed with a gastight lid. The microcalorimeter was placed in a climatic chamber at constant temperature. Samples were allowed to pre-warm in a warming cabinet for one hour in order to reactivate the microbes. Subsequently, they were equilibrated for 1 hour in measuring position before heat output data were recorded at 3-minute time intervals using the DIGITAM 3.0 program (SciTech Software, ThermoMetric, Järvalla, Sweden). The temperature in the ampules was maintained at $37^{\circ} \mathrm{C}$. There were always two parallels of one sample tested. Reproducibility of heat output was tested by incubating the same samples directly after slaughtering pigs and, again after 14 days storage in the refrigerator. 


\section{Statistics}

Data evaluation was performed using SPSS 10.0 program. All data were tested by analysis of variance considering diets and pig breeds as factors.

If $\mathrm{F}$ values in the analysis of variance were significant, mean values were analyzed with the Tukey multi comparison test.

\section{Results}

Table 3 shows the influence of the repetition on energy production during the total experimental time (energy total) and during 4 periods of 6hours (energy part 1-4). There were only 31 sample data available for repetition 2. The statistics show that there was a trend towards lower heat production of caecum content after storage in the refrigerator. Energy production during all periods and heat production were also slightly decreased, when older samples were used. However, none of these differences were significant.

Table 3: Influence of the repetition on energy production $(\mathrm{J} / \mathrm{gDM})$ and on average heat production $(\mu \mathrm{W} / \mathrm{gDM})$

\begin{tabular}{|l|c|c|c|}
\hline & Repetition 1 $(\mathrm{n}=36)$ & Repetition 2 $(\mathrm{n}=31)$ & SEM \\
\hline Energy total & 241 & 217 & 8.191 \\
\hline Energy Part 1 & 119 & 101 & 4.164 \\
\hline Energy Part 2 & 52 & 48 & 1.892 \\
\hline Energy Part 3 & 40 & 37 & 1.858 \\
\hline Energy Part 4 & 34 & 30 & 1.820 \\
\hline Heat production & 1149 & 1090 & 41.3 \\
\hline
\end{tabular}

Different superscript letters within the same row show significant differences $(p<0.05)$.

The heat production curves for samples of the three different breeds of pigs fed the two experimental diets are shown in figures 1 and 2. For better clarity only the first 12 hours after starting the measurement are shown. Caecum content of pigs that received the SBP diet showed an increased heat production compared to that of pigs fed the basal diet. Caecum content of SH pigs showed the highest while that of CB pigs showed lowest heat production, independent of the diet been fed. The heat production was high in the beginning of the measurement and then decreased to an almost constant value, with no significant differences between the breeds. 


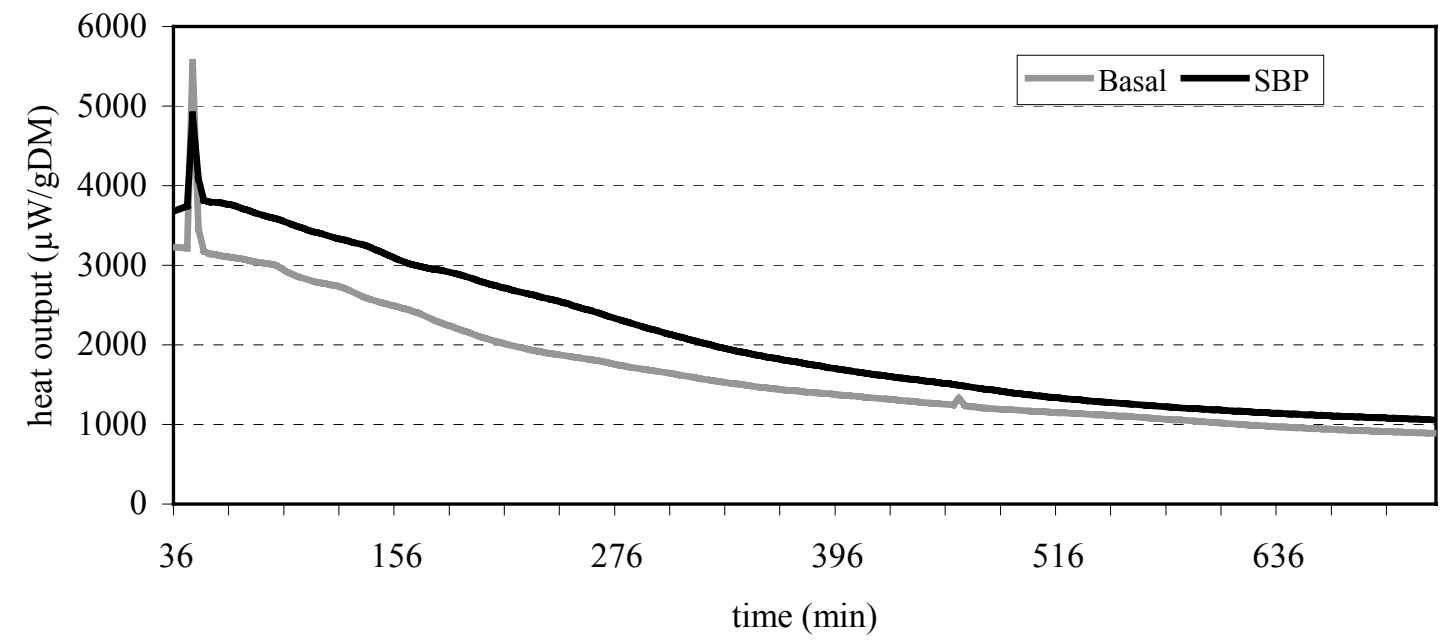

Figure 1: Heat production of caecum content from pigs fed the basal diet or the SBP diet

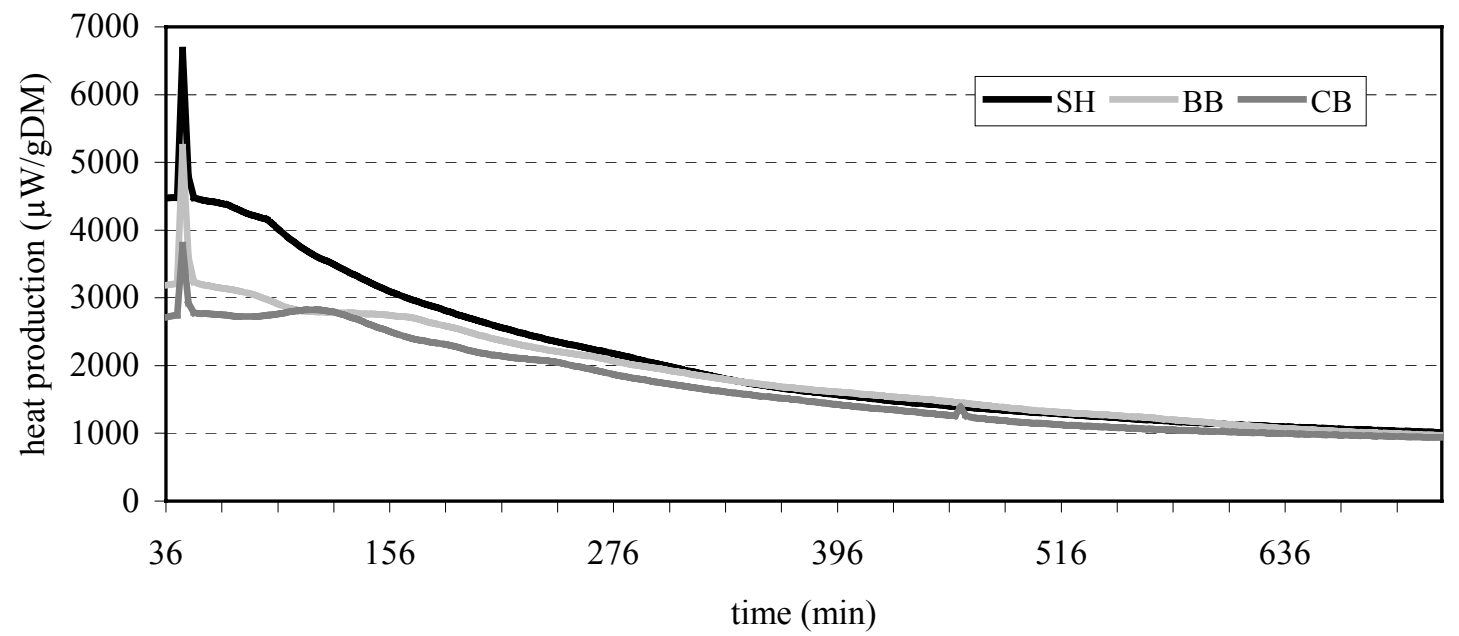

Figure 2: Heat production of caecum content of different pig breeds independent of the feed type

Table 4 shows the total energy production during the experiment, the energy production within four equal periods and the average heat production. Energy production expressed in joules is the integral of all heat production values; i.e. the area below the heat production curve as shown above. Energy production was significantly influenced by the factor diet. The factor breed showed significant differences only within the first 9 hours after start, with caecum content from SH pigs having the highest energy production while the caecum content of $\mathrm{CB}$ pigs had the lowest. 
The average heat production observed during the 24-hours experiment was only significantly influenced by the diet, not by the breed even though there was a trend to lowest heat production by caecum content of CB pigs.

Table 4: Influence of diet and breed on energy and average heat production of caecum content

\begin{tabular}{|c|c|c|c|c|c|c|c|}
\hline & \multicolumn{2}{|c|}{ Diet $(n=18)$} & \multicolumn{3}{|c|}{ Breed $(n=12)$} & \multirow{2}{*}{$\begin{array}{l}\text { Inter- } \\
\text { action }\end{array}$} & \multirow{2}{*}{ SEM } \\
\hline & Basal & SBP & SH & BB & CB & & \\
\hline $\begin{array}{l}\text { Energy prod. } \\
\text { Total (J/g DM) }\end{array}$ & $206^{\mathrm{a}}$ & $259^{\mathrm{b}}$ & 249 & 229 & 219 & 0.833 & 8.991 \\
\hline $\begin{array}{l}\text { Energy prod. } \\
\text { Part } 1 \text { (J/g DM) }\end{array}$ & $98^{\mathrm{a}}$ & $123^{b}$ & 122 & 112 & 97 & 0.967 & 4.685 \\
\hline $\begin{array}{l}\text { Energy prod. } \\
\text { Part } 2 \text { (J/g DM) }\end{array}$ & $46^{\mathrm{a}}$ & $56^{\mathrm{b}}$ & 53 & 50 & 49 & 0.788 & 1.919 \\
\hline $\begin{array}{l}\text { Energy prod. } \\
\text { Part } 3 \text { (J/g DM) }\end{array}$ & $34^{\mathrm{a}}$ & $43^{b}$ & 40 & 36 & 40 & 0.581 & 1.922 \\
\hline $\begin{array}{l}\text { Energy prod. } \\
\text { Part } 4(\mathrm{~J} / \mathrm{g} \text { DM })\end{array}$ & $29^{\mathrm{a}}$ & $37^{b}$ & 34 & 31 & 33 & 0.904 & 1.853 \\
\hline $\begin{array}{l}\text { Average heat } \\
\text { prod. }(\mu \mathrm{W} / \mathrm{DM}\end{array}$ & $969^{a}$ & $1233^{b}$ & 1170 & 1079 & 1055 & 0.730 & 44.9 \\
\hline
\end{tabular}

Different superscript letters within the same row show significant differences $(\mathrm{p}<0.05)$.

\section{Discussion}

In this experiment the possible use of microcalorimetry to determine microbial activity in the hindgut of pigs was tested. Since there was an influence of the repetition on heat production, it can be concluded that microbial activity has occurred to some extent during storage. This may have resulted in a lesser amount of substrate left for fermentation during the experiment or in a decreased viability of microbes as caused by low temperatures in the refrigerator. However the course of microbial activity was similar for both repetitions.

The breakdown of fermentable substrate by intestinal microbes resulted in heat production measured in the microcalorimeter. Higher values for heat and energy production indicate higher microbial activity. It is assumed that the measured heat output is predominantly due to microbial degradation of fermentable substrate present in the caecum content, since anabolic heat production is only a minor factor of total heat production (BELAICH, 1980).

All figures show a typical slope of heat production. The highest heat production and therefore highest microbial activity was observed in the first hours (Part 1) after starting the measurement, due to the highest supply of fermentable substrate. With decreased substrate availability after several hours, microbial activity also decreased and reached a nearly constant value. Complementary to a lack of fermentable substrate, arised fermentation products such as fatty acids, which influence the $\mathrm{pH}$ value or fermentation gases like $\mathrm{CO}_{2}$ 
which are toxic in high concentrations, may have led to a decline of microbes and their activity.

The factors diet and breed influenced the microbial activity in the caecum content of pigs. Feeding the SBP diet resulted in an elevated microbial activity caused by the elevated supply of fermentable substrate. This is in accordance with results considering fermentation characteristics achieved using the in vitro system for colon simulation (COSITEC) in a complementary experiment (study 3), where feeding the SBP diet resulted in higher production rates of short chain fatty acids and fermentation gases compared to feeding basal diet. Higher microbial activity with increased fermentable fiber consumption of pigs was also found by JENSEN \& JøRGENSEN (1994) and BACH KNUDSEN et al. (1991) using adenylate determination by luminometer.

The caecum content of SH pigs showed the highest heat and energy production and that of $\mathrm{CB}$ pigs the lowest. This indicates that the microbial activity is highest in the caecum content of SH pigs caused by the higher availability of fermentable fiber. The caecum content of BB and CB pigs showed lower microbial activity, which is assumed to result from a lower supply of fermentable substrate. Since all pig breeds received the same amount and type of fiber, differences in fiber content and composition must be a result of differences in precaecal fiber digestion among the pig breeds. The fiber of SBP is characterized as soluble non-starchpolysaccharides (NSP) and has been shown to be partly digested precaecally in pigs (GRAHAM et al., 1986). Differences in precaecal digestion among pig breeds may result from genetically-introduced divergences of gut anatomy, which are likely but not investigated so far. Changes in retention time and reduced gut motility caused mainly by water-binding properties of fiber rich feedstuff may also result in different digestibility values (JOHANSEN \& BACH KNUdSEN, 1994; JohAnsen et al., 1996; MiQuel et al., 2001).

Compared to the determination of microbial activity by means of the adenylate content in the digesta by using HPLC or luminometer without distinguishing between viable or already dead bacteria, the microcalorimeter gives the metabolic heat of viable bacteria only.

The use of flow microcalorimetry would also allow collection of fermentation gases thus offering new perspectives for studies on microbial digestive processes in animals.

Problems with the method could occur when filling the relatively small amount of one gram of digesta content in the ampoules. Even if all values are calculated on DM base, the ratios of liquid to solid phase might influence the result. Further systematic studies are recommended to clarify this point. In the present study, digesta content was carefully stirred to thoroughly distribute the bacteria and reproducibility of measurements was high. Problems could also 
occur when samples are stored for longer periods, since losses in microbial activity might occur. The use of a microcalorimeter equipped with multiple channels would enable several simultaneous measurements.

In conclusion microcalorimetry is considered to be a promissing method for determining microbial activity in gut contents. The additional supply of pigs with fiber was associated with higher heat production of caecal content in microcalorimetry thus reflecting an expected higher microbial activity in the hindgut of pigs. Furthermore, different microbial activities in the caecal contents of three pig breeds could be identified with this new methodological approach. The potential of microcalorimetry should be exploited as a valuable tool for future research in intestinal microbial digestion in domestic animals.

\section{References}

Albers, B.P.; BeEse, F.; HartmanN; A., 1995. Flow-microcalorimetry measurements of aerobic and anaerobic soil microbial activity. Biology and Fertility of Soils 19, 203208

Bach Knudsen, K.E.; Jensen, B.B.; Andersen, J.O., Hansen, I., 1991. Gastrointestinal implications in pigs of wheat and oat fractions. 2. Microbial activity in the gastrointestinal tract. British Journal of Nutrition 65, 233-248

BARJA, I. \& NÚÑEZ, L., 1999. Microcalorimetric measurements of the influence of glucose concentration on microbial activity in soils. Soil Biology and Biochemistry 31, 441447

BELAiCH, J.P., 1980. Growth and metabolism in bacteria. In: BEEZER, A.E.(ed) Biological microcalorimetry. Academic press, London. 1-42

Graham, H.; Hesselman, K.; Åman, P., 1986. The influence of wheat bran and sugar-beet pulp on the digestibility of dietary components in a cereal -based pig diet. Journal of nutrition 116, 242-251

JENSEN, B.B. \& JøRGENSEN, H., 1994. Effect of dietary fibre on microbial activity and microbial gas production. Applied and Environmental Microbiology 60, 1897-1904

JohANSEN, H.N. \& BACH KNUDSEN, K.E., 1994. Effects of wheat flour and oat mill fractions of jejunal flow, starch degradation and adsorption of glucose over an insulated loop of jejunum in pigs. British Journal of Nutrition 72, 299-313

Johansen, H. N.; BACH KnUdSEn, K.E.; SAndströM, B.; SkJøth, F., 1996. Effects of varying content of soluble dietary fibre from wheat flour and oat milling fractions on gastric emptying in pigs. British Journal of Nutrition. 75, 339-351 
MiQuel, N.; BACH KNUDSEN, K.E.; JøRGENSEN, H., 2001. Impacts of diets varying in dietary fibre characteristics on gastric emptying in pregnant sows. Archiv Tierernährung, 121145

Raubuch, M. \& BeEse, F. 1999. Comparison of microbial propertiesmeasured by $\mathrm{O}_{2}$ consumption and microcalorimetry as bioindicators in forest soils. Soil Biology and Biochemistry 31, 949-956

SPARLING, G.P., 1981. Microcalorimetry and other methods to asses biomass and activity in soils. Soil Biology and Biochemistry13, 93-98

SPARLING, G.P., 1983. Estimation of microbial biomass and activity in soil using microcalorimetry. Journal of Soil Science 34, 381-390

TeEling, H. \& CypiOnKA, H, 1997. Microbial degradation of tetraethyl lead in soil monitored by microcalorymetry. Applied Microbiology and Biotechnology 48. 275-279

Vor, T.; Dyckmans, J; Flessa, H.; BeEse; F., 2002. Use of microcalorimetry to study microbial activity during the transition from oxic to anoxic conditions. Biology and Fertility of Soils 36, 66-71 


\title{
Study 5
}

\section{Influence of dietary SBP supplement on electrophysiological parameters in pigs determined with the Ussing chamber.}

\begin{abstract}
Samples of mucosa of jejunum and colon of three different pig breeds (Schwäbisch Hällisches Schwein (SH), Buntes Bentheimer Schwein (BB) and modern crossbreed pig (CB)) fed two different diets (basal diet (B) and basal diet + sugar beet pulp (SBP)), were used to determine the influence on electrophysiological parameters (short circuit current and tissue conductances) using the Ussing chamber technique. Increasing mucosal glucose concentrations resulted in increased short circuit current in the jejunum, which was lowest for $\mathrm{CB}$ pigs and, in contrast to the other pig breeds, was not influenced by the diet. BB pigs had no dietary influence, but current response was twice as high as in CB pigs. SH pigs showed a diet-dependant effect, with currrent response being more pronounced when feeding the SBP diet.
\end{abstract}

\section{Introduction}

Several investigations have shown, that fiber rich-nutrition influences absorption of glucose in pigs, rats and human (BACH KNUDSEN et al., 2000; MiCHEL \& RÉRAT, 1998; GALIBOIS et al., 1994). While FlouRIÉ (1992) observed a delayed glucose absorption in human small intestine, total amount of absorbed glucose seemed to be unaffected by the diet (MICHEL \& RÉRAT 1998). To determine the influence of elevated dietary fiber on electrophysiological parameters, in vitro experiments were done with the Ussing chamber technique using mucosa of the mid jejunum and proximal colon of different pig breeds fed either a low fiber basal diet or the same basal diet supplemented with dried sugar beet pulp.

\section{Material and methods}

The study was carried out according to the method of USSING \& ZEHRAN (1951). This was originally developed for measuring electrolyte fluxes across the frog skin and was established for respective studies using intact epithelia of the gastrointestinal tract of mammals and birds. 


\section{Animals and feeding}

Three different breeds, two local breeds "Buntes Bentheimer Schwein" (BB), "Schwäbisch Hällisches Schwein" (SH) and a modern crossbreed pig (CB: (Landrace x Large White) x Pietrain) with 12 animals each were used for the analyses. Pigs were used for a metabolic trial first and slaughtered at the end.

The composition of experimental diets is shown in the tables 1 and 2. Amino acids were added to assure protein and amino acid supply according to requirements.

Table 1: Components of the experimental diets (\%)

\begin{tabular}{|l|c|c|}
\hline & Basal diet & SBP-diet \\
\hline Wheat & 40.00 & 32.00 \\
Barley & 29.75 & 23.80 \\
Soy bean meal & 20.00 & 16.00 \\
Potato protein & 5.00 & 4.00 \\
Premix Vilomin & 3.00 & 2.40 \\
Soy bean oil & 2.00 & 1.60 \\
L-Lysine HCl & 0.17 & 0.136 \\
DL-Methionine & 0.06 & 0.048 \\
L-Threonine & 0.02 & 0.016 \\
Sugar beet pulp & & 20.00 \\
\hline
\end{tabular}

Per kg Premix: 24\% Ca, 5\% P, 5\% Na, 1\% Mg, Additives: 400000 I.U. Vit.A, 40000 I.U. Vit.D3, 2000mg Vit.E, $500 \mathrm{mg} \mathrm{Cu}$

Table 2: DM content (\%) and ingredients (\% DM) of the experimental diets

\begin{tabular}{|l|c|c|}
\hline & Basal diet & SBP-diet \\
\hline Dry matter & 88.63 & 88.52 \\
Organic matter & 95.13 & 94.52 \\
Ash & 4.87 & 5.48 \\
Crude protein & 24.13 & 21.13 \\
Ether extract & 3.88 & 3.26 \\
Crude fiber & 3.25 & 5.83 \\
N-free extract & 63.87 & 64.30 \\
Starch & 43.99 & 35.88 \\
Sugar & 4.23 & 5.99 \\
NDF & 13.29 & 18.60 \\
ADF & 4.48 & 7.94 \\
ADL & 2.56 & 3.03 \\
Cellulose & 1.92 & 4.91 \\
Hemicellulose & 8.81 & 10.66 \\
\hline BFS & 11.69 & 19.64 \\
ME [MJ/kg DM] & 15.46 & 13.99 \\
\hline
\end{tabular}

\section{Sample preparation and incubation}

Pigs were anesthetized by stunning and killed by opening the Aa.carotids. Within 3-5 minutes samples of the mid jejunum and proximal colon were taken and poured with ice-cold physiological saline in order to free the apical membranes from digesta residues. Samples 
were stored in ice-cold serosal incubation buffer under continuous flushing with carbogen gas until the beginning of the experiments.

Intestinal segments of $3 \mathrm{~cm}$ length were opened along the mesenteric line and tunica mucosa was separated (stripped) from the tunica muscularis and serosa residues. A mucosal section of $1 \mathrm{~cm}$ was used for further analyses. Prepared epithelia of $1 \mathrm{~cm}$ diameter were fixed between the two halves of the Ussing chamber, stabilized by polyethylene webs and sealed by siliconrings. The chamber was inserted into the apparatus and attached to a gasliftsystem, consisting of two double walled glass columns. An outer liquid cycle was fed by a $37^{\circ} \mathrm{C}$ water bath to assure constant temperature. Carbogen gas in the inner cycle assured oxygen supply and constant $\mathrm{pH}$ value of the incubation solutions. Mucosal and serosal parts of epithelia were flushed by the respective incubation solution (table 3). Ussing chambers were connected to computer-operated 6-channel microclamps.

Table 3: Composition of serosal and mucosal buffer solution used in the Ussing chamber (mmol/l)

\begin{tabular}{|c|c|c|c|}
\hline \multicolumn{2}{|c|}{ serosal buffer, pH 7.4} & \multicolumn{2}{|c|}{ mucosal buffer, pH 7.4} \\
\hline $\mathrm{NaCl}$ & 113.6 & $\mathrm{NaCl}$ & 113.6 \\
\hline KCl & 5.4 & $\mathrm{KCl}$ & 5.4 \\
\hline 1n $\mathrm{HCl}$ & 0.2 & In $\mathrm{HCl}$ & 0.2 \\
\hline $\mathrm{MgCl}_{2} * 6 \mathrm{H}_{2} \mathrm{O}$ & 1.2 & $\mathrm{MgCl}_{2} * 6 \mathrm{H}_{2} \mathrm{O}$ & 1.2 \\
\hline $\mathrm{CaCl}_{2} * 2 \mathrm{H}_{2} \mathrm{O}$ & 1.2 & $\mathrm{CaCl}_{2} * 2 \mathrm{H}_{2} \mathrm{O}$ & 1.2 \\
\hline $\mathrm{NaHCO}_{3}$ & 21.0 & $\mathrm{NaHCO}_{3}$ & 21.0 \\
\hline $\mathrm{Na}_{2} \mathrm{HPO}_{4} * 2 \mathrm{H}_{2} \mathrm{O}$ & 1.5 & $\mathrm{Na}_{2} \mathrm{HPO}_{4} * 2 \mathrm{H}_{2} \mathrm{O}$ & 1.5 \\
\hline Glucose & 10.0 & Glucose & \\
\hline Mannite & 2.0 & Mannite & 2.0 \\
\hline Hepes & 7.0 & Hepes & 20.0 \\
\hline Na-gluconate & 6.0 & 2n NaOH & 6.0 \\
\hline
\end{tabular}

\section{Electrophysiological parameters}

Short circuit currents $\left(\mathrm{I}_{\mathrm{sc}}\right)$ and tissue conductances $\left(\mathrm{G}_{\mathrm{t}}\right)$ of jejunum and colon epithelia were determined basically and after addition of glucose and forskolin.

As a result of active ion transport systems transepithelial potential differences $\left(\mathrm{P}_{\mathrm{D}}\right)$ were generated, which was continually measured by the microclamp apparatus. In order to exclude passive electrically driven ion fluxes during the experimental period, potential difference was clamped to $0 \mathrm{mV}$ by introducing an external electrical current $\left(\mathrm{I}_{\mathrm{sc}}\right)$ (short circuit current conditions). This current is a sum of all electrogenic ion fluxes across the tissues. Positive $\mathrm{I}_{\mathrm{sc}}$ stands for net secretion of anions or net absorption of cations, negative $I_{s c}$ stands for net absorption of anions or a net secretion of cations.

Tissue conductance $\left(G_{t}\right)$ is the reciprocal value of tissue resistance, which is calculated from potential difference changes $(\Delta \mathrm{P})$ after application of a defined bipolar electricity pulse of 
$100 \mu \mathrm{A}(\Delta \mathrm{I})$ using the law of $\mathrm{Ohm}(\mathrm{R}=\Delta \mathrm{P} / \Delta \mathrm{I}) . \mathrm{G}_{\mathrm{t}}$ is considered to be a measure of permeability and integrity of epithelia. Electrode potentials and fluid resistance of incubation solutions between electrodes were determined to correct data collected during the experiment. Chemical gradient was excluded by ional composition of serosal and mucosal incubation buffer.

As sodium dependent glucose transport is electrogenic, current response after adding glucose can be used as an indicator for active glucose transport. Forskolin induces cAMP synthesis and therefore apical chloride secretion, which can be measured as an increase in short circuit current.

\section{Results}

Diet and breed showed an influence on short circuit current and epithelia conductance. Since there was only one animal per treatment, there could be no statistical analysis made.

\section{Short circuit current}

In jejunum the stepwise increase in mucosal glucose-concentration from 0.5 to $10.0 \mathrm{mmol} / 1$ was associated with a respective increase in short circuit current. This glucose response increased with elevated glucose concentration in all cases (figure 1). While the SBP diet led to a higher glucose response compared to the basal diet in SH pigs, the glucose response was reduced by the SBP diet in $\mathrm{BB}$ and $\mathrm{CB}$ pigs.

There was almost no electrical response observed after addition of glucose to colonic tissues. Differences among the three breeds were also not observed (figure 2). 

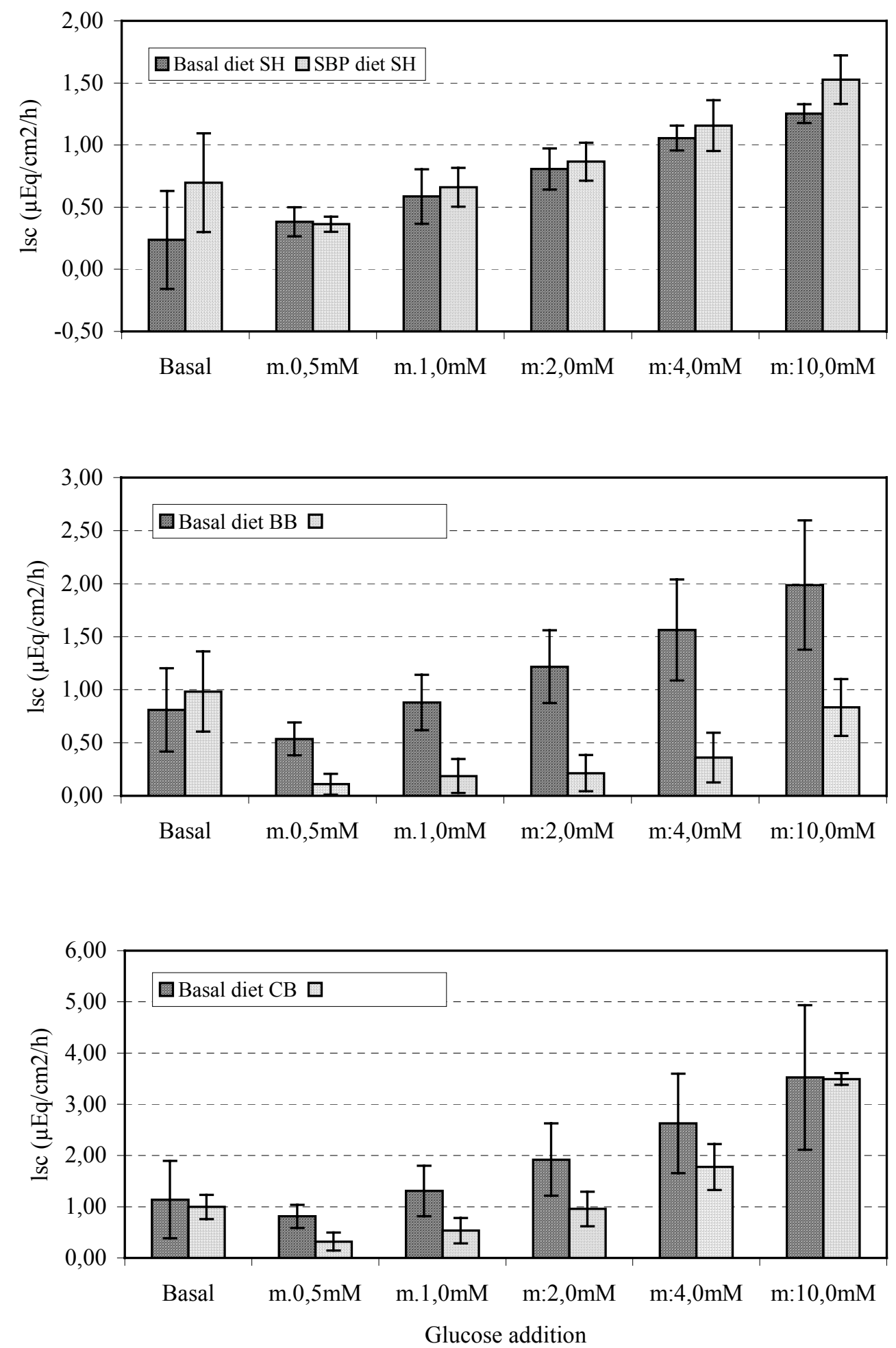

Figure 1: Influence of diet and breed on the short circuit current in the jejunal mucosa 


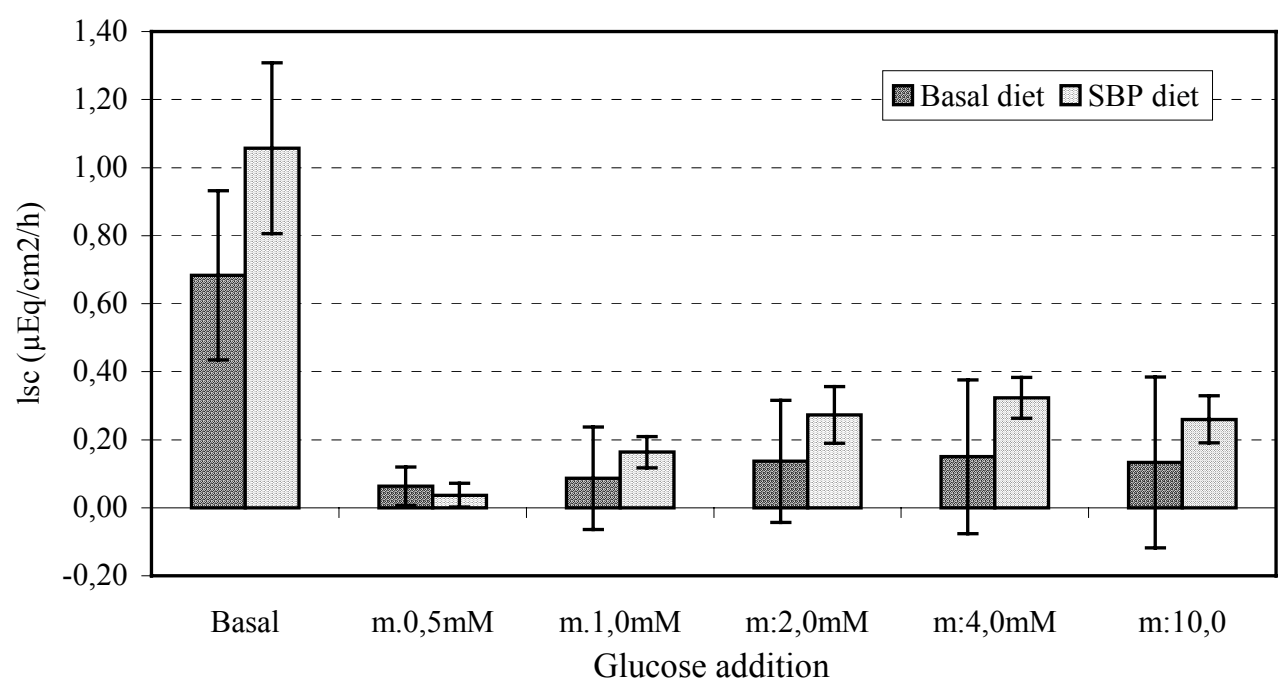

Figure 2: Influence of diet on the short circuit current in the colon mucosa on the example of SH pigs

\section{Tissue conductances}

Tissue conductances are the reciprocal values of epithelia resistance, which is calculated by potential difference after application of a current impulse. In general, tissue conductances were only slightly increased by the glucose addition. In contrast to SH pigs, which showed $20-25 \%$ higher tissue conductances when they received basal diet as feed, BB and CB pigs showed 20-25\% elevated conductances when SBP diet was fed (figure 3).

As described for short circuit current there was almost no influence of the glucose addition on the conductances in the colon mucosa, only feeding the basal diet resulted in more negative conductance values if more than $2.0 \mathrm{mM}$ glucose was added. The tissue conductances did not show any differences among the different breeds and is therefore only shown on the example of SH pigs (figure 4). 

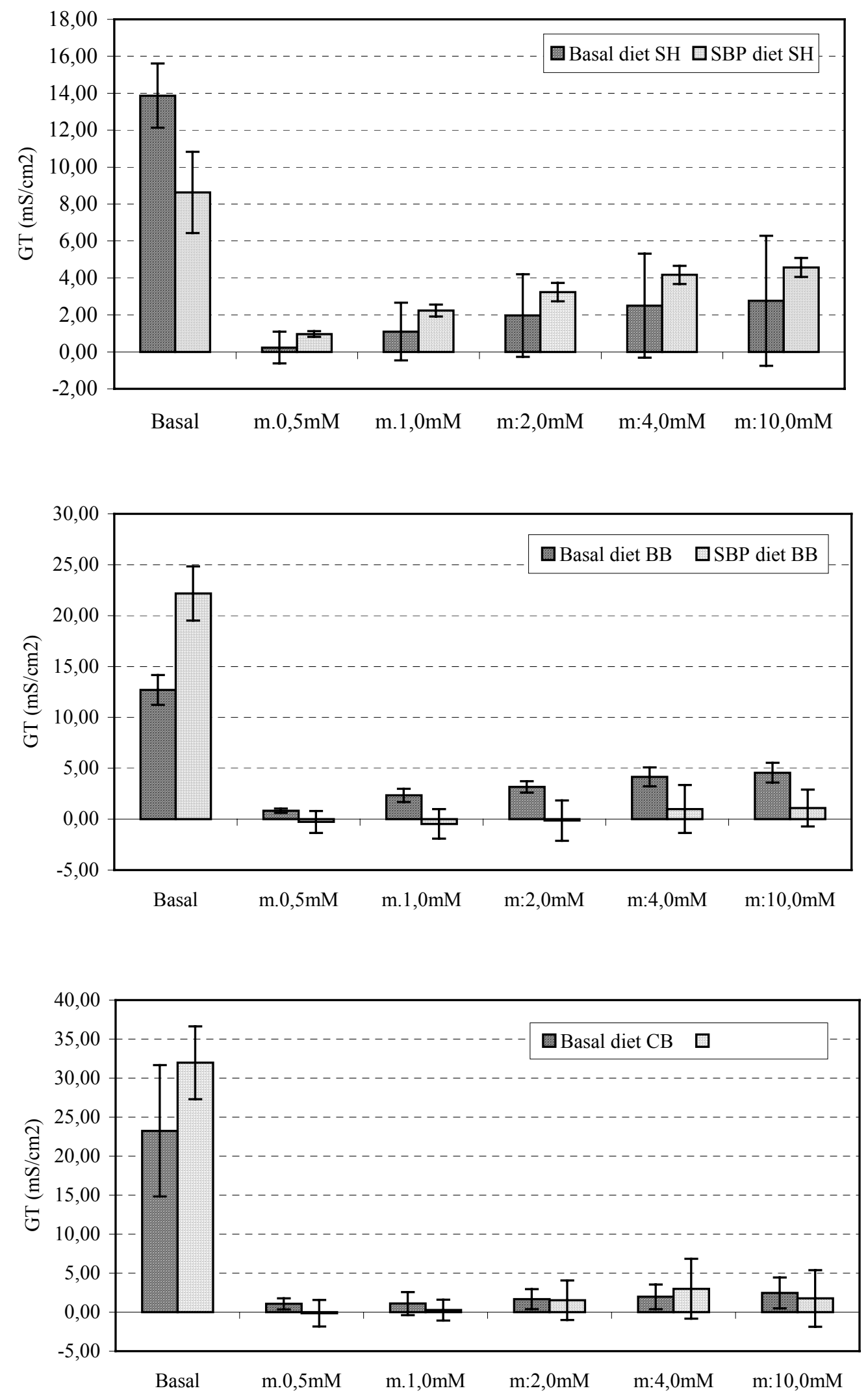

Glucose addition

Figure 3: Influence of diet and breed on the tissue conductance in the jejunal mucosa 


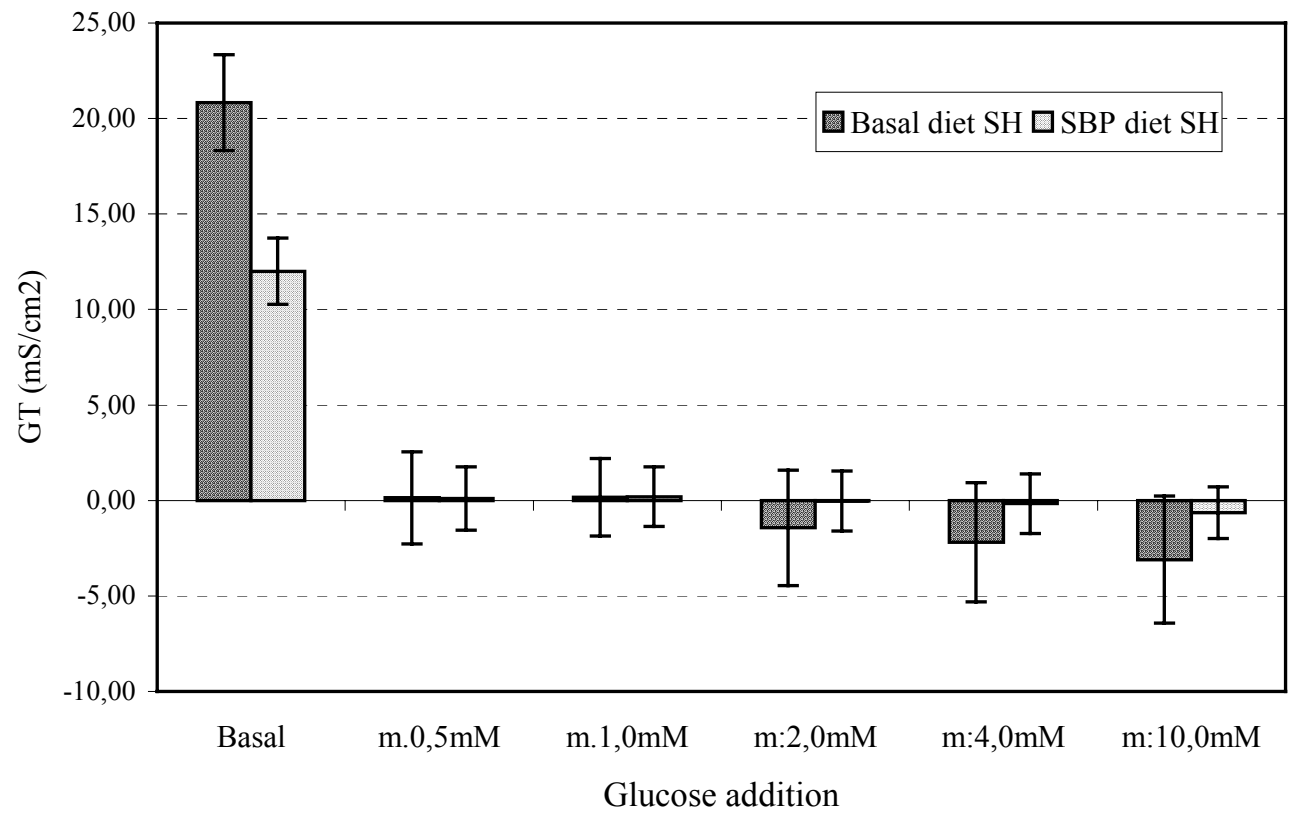

Figure 4: Influence of the diet on the tissue conductance in the colon mucosa on the example of SH pigs

\section{Discussion}

Short circuit currents and epithelia conductances were used as measures for electrical parameters of intestinal tissues, which allow conclusions on vitality and integrity of the epithelia. The values for short circuit currents and epithelia conductances are within the range of values observed for pigs in previous studies (SCHRÖDER et al, 1991; SCHRÖDER et al., 1993; SCHRÖDER et al., 1998a,b).

The results show influences of diet and breed on the electrophysiological parameters. Since all breeds received the same two diets and were killed at the same time after feeding, the results indicate, taken together with observations made in additional metabolism experiments and experiments with the Cositec system (studies 2 and 3) using the same diets and breeds, that there are differences in precaecal digestive function between the three different breeds and the two diets. In particular fiber of SBP, belonging to the fraction of soluble non-lignified NSP, is known to be already partly fermented prior to the caecum in the small intestine (GRAHAM et al., 1986). Factors resulting in different fermentation among the breeds can be morpho- or histophysiological differences. The resulting differences in digesta composition may then cause different intensities of Na-dependent glucose transport in the present study.

While there was no literature found concerning the influence of fiber on digestive processes in different breeds, differences in fiber digestion and therefore changes in nutrient absorption 
with different dietary fiber content and fiber type in crossbreed pigs are found in several studies.

While digestion and absorption of protein and fat was decreased in many investigations, there was no or only a temporary influence of fiber type and amount on glucose absorption (BACH KNUDSEn et al., 1993; BACH KNUDSEN et al., 2000; BAKKER et al., 1998; BOISEN \& FernándeZ, 1995; De LANGe et al., 1990; Drochner, 1984; EgGuM, 1992; Flourié, 1992; Galibois et al., 1994; Michel \& RÉRAT, 1998; ShI \& Noblet, 1993 a, b). There are indications for an impairment of pancreas amylase activity by NSP. This could result from a change in the $\mathrm{pH}$ value, ion exchange capacity and enzyme inhibitors as well as from a decreased secretion of amylase. Viscosity elevating properties by high water binding capacity and increased secretory processes in particular caused by soluble fiber may lead to a reduced enzyme substrate contact and substrate mucosa contact (CAMERON, 2000; FlOURIÉ, 1992; Michel \& RÉRAT, 1998; Mosenthin \& SAUER, 1993).

Differences in transport processes between pigs fed basal or SBP diet in the present study indicate, that dietary fiber also influences transport systems in the mucosa of pigs. Whether these changes in transport systems are caused by changes in carrier expression or changes in their affinity is not yet clear.

However, reduced nutrient digestion and absorption have been shown to be compensated by morpho-physiological adaptations of the animal on fiber rich diets (DERSJANT et al., 2001; JøRGENSEN et al., 1996; ZHAO et al., 1995).

In conclusion, it was deduced that the differences in electrogenic transepithelial transport function of the jejunal mucosa indicate different digestive processes and responsiveness to fiber rich nutrition of different breeds of pigs. Wether these are direct or indirect effects must be further investigated.

\section{References}

BaCh KNUdSEN, K.E.; JenSEN, B.B.; HANSEN, I., 1993. Digestion of polysaccharides and other major components in the small intestine of pigs fed on diets consisting of oat fractions rich in B-D-Glucan. British Journal of Nutrition 70, 537-556

Bach Knudsen, K.E.; Jørgensen, H.; CAniBe, N., 2000. Quantification of the adsorption of nutrients derived from carbohydrate assimilation: model experiment with pigs fed wheat or oat based rolls. British Journal of Nutrition 84 (4), 449-458

BakKer, G.C.M; DeKKer, R.A.; Jongbloed, R.; Jongbloed, A.W., 1998. Non-starch polysaccharides in pig feeding. Veterinary-Quarterly. 20 (3), 59-64 
BoISEN, S. \& FERNÁNDES, J.A., 1995. Prediction of the apparent ileal digestibility of protein and amino-acids in feedstuffs and feed mixtures for pigs by in vitro analyses. Animal Feed Science and Technology 51, 29-43

Cameron, I.L.; Hardman, W.E.; Heitman, D.W.; CARTer, J.W., 2000. Dietary fibre on cell proliferation in large bowel mucosal crypts near or away from lymphoid nodules and on mineral bioavailability. Cell Proliferation 33(6), 367-379

De LANGe, C.F.M.; Souffrant, W.B.; SAUER, W.C., 1990. Real ileal protein and amino acid digestibilities in feedstuffs for growing pigs as determined with the ${ }^{15} \mathrm{~N}$-Isotope dilution technique. Journal of Animal Science 68, 409-418

DrochneR, W., 1984. Einfluß wechselnder Rohfaser und Pektingehalte im Futter auf präcaecale und postileale Verdauungsvorgänge beim wachsenden Schwein. Fortschritte in der Tierphysiologie und Tierernährung 14, Verlag Paul Parey, Hamburg, Berlin

EgGuM, B.O., 1992. The influence of dietary fibre on protein diestion and utilisation. In: SchweIZER, T.F. \& EDWARDS, C.A. (Eds.), Dietary fibre: A component of food: Nutritional function in health and desease., ILSI Human Nutrition Reviews, SpringerVerlag, London, 153-166

FLOURIÉ, B., 1992. Influence of dietary fibre on carbohydrate digestion and adsorption. In: SCHWEIZER, T.F. \& EDWARDS, C.A (Eds.), Dietary fibre: A component of food: Nutritional function in health and desease., ILSI Human Nutrition Reviews, SpringerVerlag, London, 181-196

Galibois, I.; Desrosiers, T.; Guevin, N.; Lavigne, C.; JaQues, H., 1994. Effects of dietary fibre mixtures on glucose and lipid metabolism and on mineral adsorption in the rat. Annals of Nutrition and Metabolism 38 (4), 203-211

Graham, H.; Hesselman, K.; Åman, P., 1986. The influence of wheat bran and sugar-beet pulp on digestibility of dietary components in a cereal -based pig diet. Journal of nutrition $116,242-251$

Michel, P. \& RÉRAT, A., 1998. Effect of adding sugar beet fibre and wheat bran to a starch diet on the adsorption kinetics of glucose, amino-nitrogen and volatile fatty acids in the pig. Reproduction Nutrition Development 38, 49-68

Mosenthin, R. \& SAUER, W.C., 1993. Exocrine pancreatic secretions in pigs as influenced by the source of carbohydrate in the diet. Zeitschrift für Ernährungswissenschaft $32(2), 152-155$

SCHRÖDER, B.; KAUNE, R.; HARMEYER, J., 1991. Effects of calcitriol on stimulation of ion transport in pig jejunal mucosa. Journal of Physiology 433, 451-465

SchröDer, B.; Kaune, R.; Schlumbohm, C.; Breves, G.; Harmeyer, J., 1993. Evidence for vitamin D-independent active calcium absorption in newborn piglets. Calcified Tissue International 52, 305-309 
SCHRÖDER, B.; DAHL, M.R.; BREves, G., 1998a. Zur Rolle des Cytoskeletts bei der intestinalen $\mathrm{Ca}^{2+}$-Absorption in der frühen postnatalen Lebensphase. Zeitschrift für Gastroenterologie 36 (Suppl.1) 44-48

SCHRÖDER, B.; DAHL, M.R.; BreVES, G., 1998b. Duodenal $\mathrm{Ca}^{2+}$-absorption is not stimulated by calcitriol during early postnatal development of pigs. American Journal of Physiology. 275, G305-313

ShI, X.S. \& Noblet, J., 1993a. Digestible and metabolizable energy values of ten feed ingredients in growing pigs fed ad libitum and sows fed at maintenance level; comparative contribution of the hindgut. Animal Feed Science and Technology 42, 223-236

SHI, X.S. \& NoBlet, J., 1993b. Contribution of the hindgut to digestion of diets in growing pigs and adult sows; effect of diet composition. Livestock Production Science 34, 237235

UsSING, H.H. \& ZEHRAN, K., 1951. Active transport of sodium as a source of electric current in the short circuited isolated frog skin. Acta Physiology Scand.23, 110-127 


\title{
Study 6
}

\section{Influence of feeding diets of organically or conventionally produced feed components on digestive processes in different pig breeds.}

\begin{abstract}
The influence of feeding organic diets on nutrient digestibilities, nitrogen and mineral balances were investigated in a 2-factorial experiment with two different breeds, Buntes Bentheimer Schwein (BB) and modern crossbreed pig (CB)) and two different diets (conventional diet (CD) and organic diet (OD)) in a metabolic trial. Pigs weight was $32.5 \mathrm{~kg}$. Diets were composed of the same components, except for the main protein source, which was extracted soybean meal in the conventional diet and faba beans in the organic diet. Components in the organic diet were chosen according to the current regulations on organic farming

Feeding the OD resulted in significantly reduced digestibilities for nearly all nutrients, except for ether extract and NfE. Fecal nitrogen excretion was elevated and urinary nitrogen excretion was reduced with the organic diet. Nitrogen and mineral retentions were not significantly influenced by the diet. Only phosphorous retention was clearly reduced with feeding the OD. BB pigs showed higher nutrient digestibilities compared to CB pigs when the organic diet was fed and the breed also influenced mineral balances.
\end{abstract}

\section{Introduction}

Based on the guidelines from different organic farming associations, production terms are different from those commonly used in conventional farming (BUNDESMINISTERIUM FÜR VERBRAUCHERSCHUTZ, ERNÄHRUNG UND LANDWIRTSCHAFT, 2002; BIOLAND, 2001; DEMETER, 2002; NATURLAND, 2002).

It can be assumed that lower nutrient availability and the special plant protection strategy followed in organic farming lead to modified ripening processes and thus to another composition of nutrients and other plant ingredients than those in conventionally-produced feedstuff (BRANDT \& MølgaARD, 2001; WOESE et al., 1995, 1997).

Moreover, home grown seed legumes like faba beans, peas and lupines constitute the main feed protein sources instead of soybean meal. These home grown feedstuffs may differ in nutrient availability from soybean meal due to specific secondary plant constituents, which restrict their use as feed components in conventional farming, documented by recommended 
upper limits for their inclusion into diets for domestic animals (JEROCH et al., 1993; ABEL, 1996; ABEL et al., 2002).

It is widely unknown by now, to what extend such changes in feedstuff and diets affect the digestive physiology of pigs.

Consequent selection based on high daily body weight gains and high feed utilization with feeding concentrated feedstuff could have changed digestive processes in modern crossbreed pigs, extensively used in conventional and organic farming.

The objective of this experiment was to compare the effects of feeding diets containing organically or conventionally produced feed compounds on digestive processes in a modern crossbreed pig and an old local pig breed.

\section{Material and methods}

\section{Animals, feeding and housing of animals}

Digestive processes were studied in castrated male pigs of two different pig breeds with 6 animals each. Breeds were "Buntes Bentheimer Schwein" (BB), as a representative of an old local breed, and a modern crossbreed pig (CB: (Landrace x Large White) x Pietrain). The pigs had an average body weight of $32.5 \mathrm{~kg}$ at the beginning of the collection period.

After arriving at university, the pigs were first kept in the pigpen for one week in order to recover from transport stress. After that they were housed individually in metabolism cages, which allowed separate collection of feces and urine and feed residues and assured an exact feed allotment. The total experimental period was divided into a seven-day adaptation period and a five-day collection period.

In this experiment two different diets were fed. The composition of the diets is shown in tables 1 and 2. The conventional diet consisted of wheat, barley, soybean meal, maize gluten, minerals and a premix. Extracted soybean meal was used as the main protein source. In the organic diet cereals and faba beans were of organic production, whereas conventional potato protein and maize gluten were added as protein supplements according to the current regulations on organic farming. These conventional protein sources served to elevate the protein quality and the methionine deficiency, in particular, which would be associated with the use of faba beans as the main feed protein source in the organic diet. 
Table 1: Components of the experimental diets (\%)

\begin{tabular}{|lc|lc|}
\hline \multicolumn{2}{|c|}{ Conventional diet } & \multicolumn{2}{c|}{ Organic diet } \\
\hline Wheat & 34 & Wheat & 34 \\
Barley & 30 & Barley & 30 \\
Potato Protein & 6 & Potato Protein & 6 \\
Premix & 3 & Premix & 3 \\
Maize gluten & 2 & Maize gluten & 2 \\
\hline Soy bean meal & 13 & Faba bean & 25 \\
Wheat & 5 & & \\
Barley & 7 & & \\
\hline
\end{tabular}

Per kg Premix: 24.5\% Ca, 5.0\% P, 5.5\% Na, 1\% Mg, Additives: 400000 I.U. Vit.A, 40000 I.U. Vit.D3, $2000 \mathrm{mg}$ Vit.E, 500mg Cu

Table 2: Content DM (\%) and ingredients (\% DM) of the experimental diets

\begin{tabular}{|l|c|c|}
\hline \multicolumn{1}{|c|}{ Ingredients } & \multicolumn{2}{|c|}{ Diet } \\
\hline Dry matter & Conventional diet & Organic diet \\
Organic matter & 89.99 & 89.51 \\
Ash & 95.32 & 95.19 \\
Crude protein & 4.68 & 4.81 \\
Ether extract & 23.36 & 22.20 \\
Crude fiber & 2.08 & 1.98 \\
N-free extract & 3.18 & 4.27 \\
NDF & 66.70 & 66.74 \\
ADF & 13.23 & 14.34 \\
Starch & 5.16 & 7.01 \\
Sugar & 46.86 & 49.43 \\
\hline BFS & 2.79 & 2.35 \\
ME & 13.21 & 10.30 \\
\hline
\end{tabular}

Pigs were fed twice daily at $8 \mathrm{pm}$ and $4 \mathrm{am}$. The daily amount of feed was divided into two equal portions. It was adjusted to the pig weight and average daily body weight gain, as ascertained in the adaptation period. Both diets were fed at the rate of $0.095 \mathrm{~kg} / \mathrm{kg}$ metabolic body weight and day. Before feeding, feed was mixed with water to achieve complete intake. Feed intake was $99.9 \%$ for the conventional diet and $99.7 \%$ for the organic diet. Furthermore, feed intake was $100 \%$ for CB pigs and $99.6 \%$ for BB pigs. Water was given ad libitum.

\section{Sample collection}

Feed samples were taken with the beginning of experimental period and before weighing out daily feed amount. Samples were ground to a thickness of $0.5 \mathrm{~mm}$ and stored at a dry place for analysis.

Feces were collected and weighed twice daily after feeding and stored frozen at $-20^{\circ} \mathrm{C}$. At the end of the collection period total feces of each animal were homogenized with a cutter and samples taken for dry matter content and protein determination. A subset of feces was refrozen and stored at $-20^{\circ} \mathrm{C}$ for further analysis. 
Urine was collected and weighed once daily. In order to prevent ammonia-N losses, $150 \mathrm{ml}$ of $30 \%$ sulphuric acid were added in the collection bottle. An aliquot of $10 \%$ of daily urine was taken and frozen at $-20^{\circ} \mathrm{C}$.

\section{Analyses}

Weende analysis

Feed, feed residues, feces and urine were analyzed according to the Weende analysis.

Samples of feces were homogenized in a cutter (EMS, Eduard Müller\& Söhne, Saarbrücken) before analysis. Protein determination was carried out directly with homogenized fresh feces. For all other analyses, feces which were dried at $60^{\circ} \mathrm{C}$ and ground to $0.5 \mathrm{~mm}$ were used.

NDF and ADF were determined according to the method of GOERING\& VAN SOEST (1970).

Starch content in the diet was determined polarmetrically according to the Verbandsmethode of VDLUFA (NAUMANN\& BASSLER, 1976). Sugar content was determined according to the method of Luff- Schorl (NAUMANN\& BASSLER, 1976).

\section{Minerals}

Mineral analyses in feed, feed residues, feces and urine were carried out after pressure digestion with $65 \%$ concentrated $\mathrm{HNO}_{3}$ according to the method of LOFTFIELD \& BEESE (1999). The elements sodium, potassium, magnesium, phosphorus and sulphur were determined with ICP-AIS (Spectro Analytical Instruments, Kleve, Germany).

\section{Calculations and statistics}

Data evaluation was performed using SPSS 10.0 program. All data were tested by analysis of variance considering diets and breeds as factors.

\section{Results}

\section{Digestibility}

Diet and breed as shown in table 3 influenced the digestibility of nutrients. Feeding the diet composed of organic produced feed components led to a reduced digestibility for dry matter, organic substance, protein, ash, NfE, crude fiber, NDF and ADF. 
Considering the breed, CB pigs showed lower digestibility for dry matter, organic substance and crude protein compared to BB pigs. There was no interaction between the factors diet and breed. The diet composition showed a greater influence on digestibility than the breed.

Table 3: Influence of diet and pig breed on nutrient digestibility (\%)

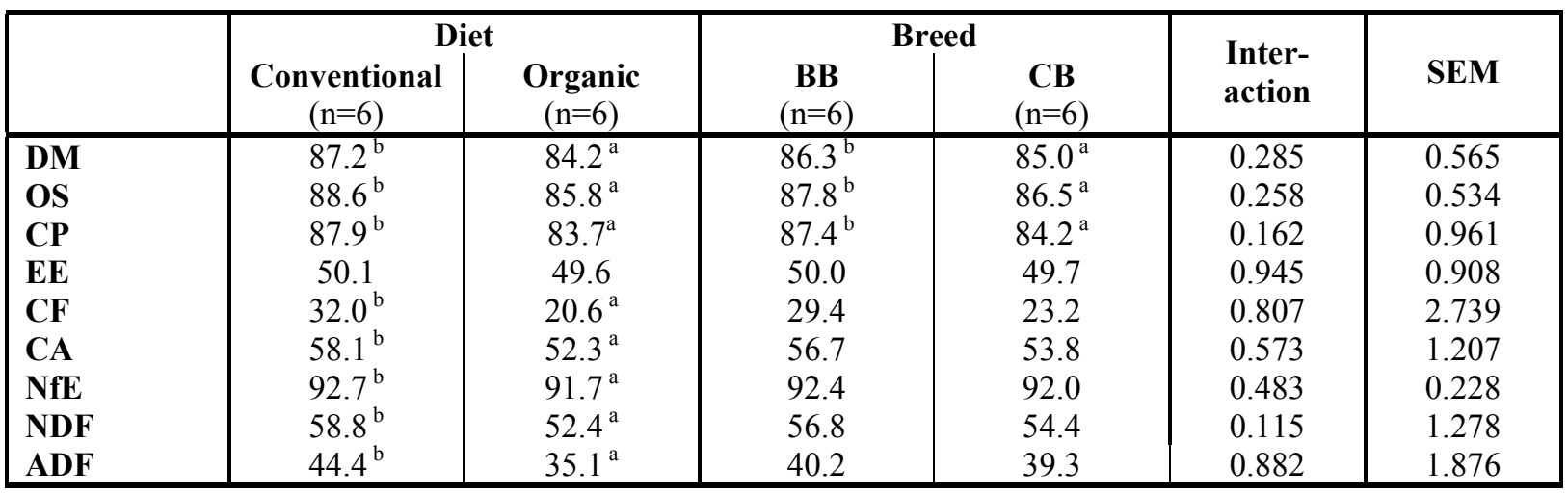

Different superscript letters within the same row show significant differences $(p<0.05)$.

\section{N-Balances}

The results for N-balances are given in table 4. According to differences in protein content in the diet, the $\mathrm{N}$ intake was slightly different between conventionally and organically fed pigs. The excretion was also influenced by the diet, with more $\mathrm{N}$ being excreted via feces and less via urine when the organic diet was fed. The N-retention was not affected by the diet.

The factor breed showed no influence on $\mathrm{N}$ intake, but on $\mathrm{N}$ excretion, which was higher for $\mathrm{CB}$ pigs. This was caused by the elevated fecal $\mathrm{N}$ excretion of $\mathrm{CB}$ pigs compared to $\mathrm{BB}$ pigs. The breed did not affect urine N-excretion.

N-retention showed a higher trend for $\mathrm{BB}$ pigs compared to that for $\mathrm{CB}$ pigs, but the difference was not significant.

Table 4: Influence of diet and breed on N-balances during metabolism trial

\begin{tabular}{|c|c|c|c|c|c|c|}
\hline & \multicolumn{2}{|c|}{ Diet } & \multicolumn{2}{|c|}{ Breed } & \multirow{2}{*}{$\begin{array}{l}\text { Inter- } \\
\text { action }\end{array}$} & \multirow[b]{2}{*}{ SEM } \\
\hline & $\begin{array}{c}\text { Conventional } \\
(\mathrm{n}=6)\end{array}$ & $\underset{(\mathrm{n}=6)}{\operatorname{Organic}}$ & $\begin{array}{c}\mathbf{B B} \\
(\mathrm{n}=6)\end{array}$ & $\begin{array}{c}\mathbf{C B} \\
(\mathrm{n}=6)\end{array}$ & & \\
\hline Intake $\left(\mathrm{g} / \mathrm{d}^{*} \mathrm{~kg}^{0.75}\right)$ & 3.36 & 3.17 & 3.24 & 3.29 & 0.644 & 0.030 \\
\hline $\begin{array}{l}\text { Excretion } \\
\text { Feces }\left(\mathrm{g} / \mathrm{d} * \mathrm{~kg}^{0.75}\right) \\
\% \text { of intake } \\
\text { Urine }\left(\mathrm{g} / \mathrm{d} * \mathrm{~kg}^{0.75}\right) \\
\% \text { of intake }\end{array}$ & $\begin{array}{c}0.41^{\mathrm{a}} \\
12.10^{\mathrm{a}} \\
1.35^{\mathrm{b}} \\
40.25^{\mathrm{b}}\end{array}$ & $\begin{array}{c}0.52^{\mathrm{b}} \\
16.29^{\mathrm{b}} \\
1.12^{\mathrm{a}} \\
35.25^{\mathrm{a}}\end{array}$ & $\begin{array}{c}0.41^{\mathrm{a}} \\
12.62^{\mathrm{a}} \\
1.24 \\
37.46\end{array}$ & $\begin{array}{c}0.51^{\mathrm{b}} \\
15.77^{\mathrm{b}} \\
1.23 \\
38.04\end{array}$ & $\begin{array}{l}0.181 \\
0.162 \\
0.105 \\
0.119\end{array}$ & $\begin{array}{l}0.028 \\
0.961 \\
0.048 \\
1.269\end{array}$ \\
\hline $\begin{array}{l}\text { Retention }\left(\mathrm{g} / \mathrm{d}^{*} \mathrm{~kg}^{0.75}\right) \\
\% \text { of intake }\end{array}$ & $\begin{array}{c}1.60 \\
47.66\end{array}$ & $\begin{array}{c}1.54 \\
48.46\end{array}$ & $\begin{array}{c}1.64 \\
49.92\end{array}$ & $\begin{array}{c}1.50 \\
46.19\end{array}$ & $\begin{array}{l}0.070 \\
0.070\end{array}$ & $\begin{array}{l}0.049 \\
1.456\end{array}$ \\
\hline
\end{tabular}

Different superscript letters within the same row show significant differences $(p<0.05)$. 


\section{Mineral balances}

Balances of calcium, phosphorus, sodium, potassium and magnesium are shown in table 5.

Table 5: Influence of diet and pig breed on mineral balances

\begin{tabular}{|c|c|c|c|c|c|c|}
\hline & \multicolumn{2}{|c|}{ Diet } & \multicolumn{2}{|c|}{ Breed } & \multirow{2}{*}{$\begin{array}{l}\text { Inter- } \\
\text { action }\end{array}$} & \multirow[b]{2}{*}{ SEM } \\
\hline & $\begin{array}{c}\text { Conventional } \\
(\mathrm{n}=6)\end{array}$ & $\begin{array}{c}\text { Organic } \\
(\mathrm{n}=6)\end{array}$ & $\begin{array}{c}\mathbf{B B} \\
(\mathrm{n}=6)\end{array}$ & $\begin{array}{c}\mathbf{C B} \\
(\mathrm{n}=6)\end{array}$ & & \\
\hline $\begin{array}{l}\text { Calcium } \\
\text { Intake }\left(\mathrm{mg} / \mathrm{d}^{*} \mathrm{~kg}^{0.75}\right)\end{array}$ & $884.9^{\mathrm{a}}$ & $937.5^{\mathrm{b}}$ & $904.1^{\mathrm{a}}$ & $918.3^{\mathrm{b}}$ & 0.964 & 8.251 \\
\hline Feces & $377.2^{\mathrm{a}}$ & $431.5^{b}$ & 402.2 & 406.3 & 0.246 & 13.662 \\
\hline Urine & 24.4 & 33.9 & $17.7^{\mathrm{a}}$ & $40.5^{\mathrm{b}}$ & 0.190 & 5.153 \\
\hline Retention & 483.5 & 472.2 & 454.0 & 471.5 & 0.143 & 12.361 \\
\hline Phosphorus & & & & & & \\
\hline Intake $\left(\mathrm{mg} / \mathrm{d}^{*} \mathrm{~kg}^{0.75}\right)$ & $593.7^{b}$ & $513.1^{\mathrm{a}}$ & 548.4 & 558.3 & 0.960 & 12.253 \\
\hline Feces & $274.7^{\mathrm{a}}$ & $340.1^{b}$ & 308.5 & 306.3 & 0.177 & 11.670 \\
\hline Urine & 2.6 & 1.7 & 1.7 & 2.6 & 0.977 & 0.300 \\
\hline Retention & $316.4^{\mathrm{b}}$ & $171.3^{\mathrm{a}}$ & 238.2 & 249.4 & 0.200 & 22.890 \\
\hline Sodium & & & & & & \\
\hline Intake $\left(\mathrm{mg} / \mathrm{d}^{*} \mathrm{~kg}^{0.75}\right)$ & 184.4 & $\begin{array}{l}190.6 \\
326\end{array}$ & $\begin{array}{c}185.9 \\
331\end{array}$ & $\begin{array}{c}189.0 \\
31.9\end{array}$ & $\begin{array}{l}0.566 \\
0.454\end{array}$ & $\begin{array}{l}1.060 \\
1.832\end{array}$ \\
\hline $\begin{array}{l}\text { Feces } \\
\text { Urine }\end{array}$ & $\begin{array}{l}32.6 \\
45.2\end{array}$ & $\begin{array}{l}32.6 \\
47.8\end{array}$ & $\begin{array}{l}53.1 \\
45.2\end{array}$ & $\begin{array}{l}11.9 \\
47.8\end{array}$ & $\begin{array}{l}0.4 J 4 \\
0.388\end{array}$ & 1.640 \\
\hline Retention & 106.7 & 110.1 & 107.6 & 109.3 & 0.983 & 1.716 \\
\hline Potassium & & & & & & \\
\hline Intake $\left(\mathrm{mg} / \mathrm{d}^{*} \mathrm{~kg}^{0.75}\right)$ & $633.9^{\mathrm{a}}$ & $639.4^{\mathrm{b}}$ & 631.5 & 641.8 & 0.867 & 1.797 \\
\hline Feces & 131.9 & 148.7 & 147.0 & 133.6 & 0.135 & 6.665 \\
\hline Urine & 241.5 & 222.9 & $147.0^{\mathrm{a}}$ & $317.4^{\mathrm{b}}$ & 0.267 & 34.065 \\
\hline Retention & 261.0 & 267.7 & $337.5^{\mathrm{b}}$ & $190.8^{\mathrm{a}}$ & 0.415 & 29.588 \\
\hline Magnesium & & & & & & \\
\hline Intake $\left(\mathrm{mg} / \mathrm{d}^{*} \mathrm{~kg}^{0.75}\right)$ & $142.1^{\mathrm{a}}$ & $148.4^{\mathrm{b}}$ & 145.0 & 146.4 & 0.777 & 1.024 \\
\hline Feces & 103.3 & 101.2 & 104.7 & 99.7 & 0.113 & 1.607 \\
\hline Urine & 11.4 & 17.2 & $9.5^{\mathrm{a}}$ & $19.1^{\mathrm{b}}$ & 0.856 & 2.316 \\
\hline Retention & 27.3 & 30.0 & 29.8 & 27.5 & 0.310 & 2.440 \\
\hline
\end{tabular}

Different superscript letters within the same row show significant differences $(\mathrm{p}<0.05)$.

Feeding the organic diet led to an elevated calcium intake compared to feeding the conventional diet. Pigs that received the organic diet showed a trend for elevated calcium excretion via urine and a significantly elevated fecal calcium excretion. Thus, feeding the organic diet reduced calcium retention, although not to a significant extent.

Phosphorous intake was significantly reduced when feeding the organic compared to feeding the conventional diet. However, fecal excretion of pigs fed organically was about 65.4 $\mathrm{mg} / \mathrm{d}^{*} \mathrm{~kg}^{0.75}$ higher than that of conventionally fed pigs, resulting in a lower phosphorous retention of about $145.1 \mathrm{mg} / \mathrm{d}^{*} \mathrm{~kg}^{0.75}$ in organic pigs.

Potassium- and magnesium intake was elevated in organically fed pigs. Significant differences in urinary and fecal excretions as well as differences in retention of these minerals were not observed between both diets. Intake, excretion and retention of sodium were not influenced by the diet. 
Due to feed residues the intake of phosphorous, sodium, potassium and magnesium was slightly, and in the case of calcium was significantly, reduced for BB pigs.

There were no significant differences in fecal mineral excretions between the two breeds observed, whereas urinary excretion of calcium, magnesium and potassium was clearly elevated for $\mathrm{CB}$ compared to BB pigs.

Mineral retention only differed significantly between the breeds in the case of potassium, with $\mathrm{CB}$ pigs showing a $146.7 \mathrm{mg} / \mathrm{d}^{*} \mathrm{~kg}^{0.75}$ lower retention than BB pigs.

\section{Discussion}

The present study was carried out in order to investigate the influence of diets composed of organic or conventional feed components on nutrient digestibility in pigs. The diets been used were composed of components, which could be used in either practical organic or conventional pig production. Both diets are calculated to be nearly isoenergetic and isonitrogenous. The feed components were produced under conventional or organic production guidelines respectively, with the exception of potato protein and maize gluten, which are allowed to be used as conventionally produced supplements in organic feeding. Diets mainly varied in the protein source: in the case of the conventional diet, extracted soybean meal was used as main protein source, whereas in the case of the organic diet, faba beans (cultivar Divine) were used. Faba beans were chosen because of their relatively high protein content (compared to peas) and the lack of organically produced soybeans in Germany.

The pig breeds being used for the experiment were Buntes Bentheimer Schwein as a representative of an old pig breed, which is considered avoided the extreme breeding process as compared to modern crossbreed pigs, used as the second breed in this study.

Chemical analysis of the diets show, that both diets differed slightly in their protein and fiber content. The conventional diet contained more protein while the organic diet contained more crude fiber, NDF and ADF. These deviations mainly resulted from the different protein sources but also because the cereal feed components were produced either organically or conventionally. There are several observations in the literature as well as in the present study (Study 1) showing the influence of the cultivation method on nutrient composition of these feed components (BRAndt \& MølgaArd, 2001; Dloughy, 1981; Haglund, 1998; KLein, 1968; Kieffer, 1995; Kumpulainen, 2001; Mølgaard, 2000; Petterson, 1982; RaupP et al., 1994, SCHELler, 1999; WoESE et al., 1995, 1997; WOLFSON \& SHEARER, 1981). 
Differences in the diets must have led to the different digestibilities noted in the metabolic trial. The organic diet led to significantly lower digestibilities for dry matter, crude protein crude ash, crude fiber, NDF and ADF. One factor for the reduced digestibility values could have been the higher fiber ingestion with feeding the organic diet. Another factor surely was the type of fiber, which must be assumed to have differed between the two diets.

Dietary fiber consisting of non-starch-polysaccharides is not degradable by endogenous enzymes in pigs. Whereas soluble NSP can already be broken down into smaller molecules in the small intestine, insoluble NSP, with a probable higher content in organic diets as a result of the agronomic methods, are only substantially fermented in the caecum and colon of pigs (BACH KNUdSEN et al., 1993b; BACH KNUdSEN \& CANIBE, 2000). This means they are present during the whole digestive process in the intestine tract.

Due to their water binding properties and their ability to stimulate secretion of digestive juices, elevated fiber contents lead to changes in digesta passage rate through the gastrointestinal tract. This influences mixing of digesta, enzyme-substrate interaction by forming of a water layer between mucosa and digesta and also nutrient absorption. These actions, together with an increased synthesis of microbial protein and fat, results in decreased true and apparent nutrient digestibility, as was also observed in the present study (study 2) (Drochner, 1984; EdWARdS, 1990; Flourié, 1992; FurdA, 1990; GRAHAM et al., 1986; JOHANSEN \& BACH KNUDSEN, 1994; JOHANSEN et al., 1996; Kestling et al., 1991; Low, 1989; Low, 1990; PotKIns et al., 1991; READ \& EASTWOOD, 1992; WisKeR \& FELdHEIM, 1992).

The faba bean cultivar Divine was used as the protein source in the organic diet. This faba bean variety is colored flowering and therefore rich in tannins, but low in vicine and convicine content. Its energy value for pigs equals that of other colored flowering faba beans (ABEL \& BURGHARD, 2002). The protein digestibility of the organic diet was presumably also mainly reduced due to tannins (BURGHARD, 2001; GRALA et al., 1999; JANSMAN et al., 1995). Lower protein digestibility and absorption must be responsible for the increased fecal and reduced urinary $\mathrm{N}$-excretion in pigs fed the organic compared to those fed the conventional diet in the present study.

The influence of the fiber in the organic diet must also be responsible for changes in mineral balances especially as observed for calcium and phosphorous in the present study. This influence was also observed for mineral balances in other investigations (BAKKER et al., 1998; Drochner, 1984; GALIBOIS et al., 1994; JONGBLOED \& MrOZ, 1997; KROYER et al., 1995). In vitro experiments have shown mineral-binding and complex-binding capabilities of fiber and 
fiber associated substances (FRØLICH, 1990; ROSSANDER et al., 1992), which could lead to a reduced mineral absorption in the intestine of pigs when feeding fiber rich feedstuff. Complexes between minerals and other substances may also have increased fecal excretion and lowered retention of phosphorous in organically fed pigs, suggesting that this mineral mainly occured in the form of phytin phosphorous.

While this experiment only used diets containing organic or conventionally produced components, it is assumed that the fiber content in organic feeding is even more elevated under practical feeding conditions of organic farming by the stipulation of a daily supply of roughage for every pig. This would cause even stronger influences on digestive processes than shown in this study.

No comparable experiments using different pig breeds (old local breed and modern crossbreed) have been conducted as yet, despite the fact that organic farming is a growing sector in agriculture. Even though there were differences observed in the ability to digest organic diets, older pig breeds should be given much greater consideration for pig production in organic farming.

\section{References}

ABel, Hu., 1996. Verwendungspotentiale und Probleme. In: Brinkmann, J. \& ABel, Hu (Eds): Potentiale und Perspektiven des Körnerleguminosenanbaus in Deutschland. 7 Tierernährung, ufob- Schriften, Vol. 3, Bonn, 161-208

ABEL, HJ. \& Burghard, M.G., 2002. Untersuchungen an wachsenden Schweinen zum Futterwert einer neuen Ackerbohnensorte (Vicia faba L.) bei Ergänzung mit DLMethionin oder DL-Methionin- Hydroxyanalog, Journal of Animal Physiology and Animal Nutrition 86, 26-35

Abel, HJ.; Rothenberger, L.G.; MAinKA, S., 2002. Ackerbohnen in der Tierernährung. Übersicht Tierernährung 30, 109-133

Bach Knudsen, K.E.; Jensen, B.B ; Hansen, I., 1993b. Digestion of polysaccharides and other major components in the small intestine of pigs fed on diets consisting of oat fractions rich in B-D-Glucan. British Journal of Nutrition 70, 537-556

BACH KNudsen, K.E. \& CANiBE, N., 2000. Breakdown of plant carbohydrates. Journal of Science of Food and Agriculture 80, 1252-1261

BakKer, G.C.M; DekKer, R.A.; Jongbloed, R.; Jongbloed, A.W., 1998. Non-starch polysaccharides in pig feeding. Veterinary-Quarterly. 20 (3), 59-64

BIOLAND, 2001. Bioland Richtlinien, www.bioland.de/bioland/richtlinien/erzeugerrichtlinien.pdf, March 2004 
BRAND, K. \& MølgaARD, J.P., 2001. Organic agriculture: does it enhance or reduce the nutritional value of plant foods. Journal of Science of Food and Agriculture 81, 924931

BUNDESMINISTERIUM FÜR VERBRAUCHERSCHUTZ, ERNÄHRUNG UND LANDWIRTSCHAFT, 2004. Verordnung (EWG) Nr. 2092/91 (EG-Öko-Verordnung) und Folgerecht. Www.verbraucherministerium.de/indexCC50A5785E6947818086B26C12A90287.html

BuRghARD, M.G. 2001. Sortenspezifische Untersuchungen zu Ackerbohnen als Futterkomponente für Schweine. Dissertation Universität Göttingen

DEMETER, 2002. Richtlinien Erzeugung. www.demeter.de/demeter/dem_richtlinien.pdf, March 2004

DLOUHY, J., 1981. Alternativa odlingsformer-växtprodukters kvalität vid konventionell och biodynamisk odling, Sveriges Lantbruksuniversitet, Institut för växtodling, Rapport 91, Uppsala

DrochNer, W., 1984. Einfluß wechselnder Rohfaser und Pektingehalte im Futter auf präcaecale und postileale Verdauungsvorgänge beim wachsenden Schwein. Fortschritte in der Tierphysiologie und Tierernährung 14, Verlag Paul Parey, Hamburg, Berlin

EDWARDS, C., 1990. Mechanisms of action of dietary fibre on small intestine adsorption and motility. In: FURDA, I. \& BRINE, C.J. (Eds.), New developments in dietary fibre: physiological, physiochemical and analytical aspects. Advances in experimental medicine and biology, Vol.270, Plenum Press, New York, London

FlouRIÉ, B., 1992. Influence of dietary fibre on carbohydrate digestion and adsorption. In: SchweIzer, T.F. \& EDwards, C.A. (Eds.), Dietary fibre: A component of food: Nutritional function in health and desease., ILSI Human Nutrition Reviews, SpringerVerlag, London, 181-196

FrøLICH, W., 1990. Chelating properties of dietary fiber and phytate. The role for mineral availability. In: FURDA, I. \& BRINE, C.J. (Eds.), New developments in dietary fibre: physiological, physiochemical and analytical aspects. Advances in experimental medicine and biology, Vol. 270, Plenum Press, New York, London

FURDA, J., 1990. Interaction of dietary fibre with lipids-mechanistic theories and their limitations. In: FURDA, I. \& BRINE, C.J. (Eds.), New developments in dietary fibre: physiological, physiochemical and analytical aspects. Advances in experimental medicine and biology, Vol.270, Plenum Press, New York, London, 67-82

Galibois, I.; Desrosiers, T.; Guevin, N.; LAVigne, C.; JaQues, H., 1994. Effects of dietary fibre mixtures on glucose and lipid metabolism and on mineral adsorption in the rat. Annals of Nutrition and Metabolism 38 (4), 203-211

Goering, H.K. \& VAn Soest, P.J., 1970. Forage fiber analysis. Apparatus, reagents, procedures and some applications. Agricult. Handbook No. 379, Agricultural Research Service, Dep. of documents, US Government Printing off., Washington, DC, 20 pages 
Graham, H.; Hesselman, K.; ÅmAn, P., 1986. The influence of wheat bran and sugar-beet pulp on digestibility of dietary components in a cereal -based pig diet. Journal of Nutrition 116, 242-251

Grala, W.; Verstegen; M.W.A.; Jansman, A.J.M.; Huisman, J.; VAn Leuwen, P., 1999. Apparent protein digestibility and recovery of endogenous nitrogen at the terminal ileum of pigs fed diets containing various soyabean products, peas or rapeseed hulls. Animal Feed Science and Technology 80, 231-245

Haglund, Å.; Johansson, L.; DAhlstedt, L., 1998. Sensory evaluation of wholemeal bread from ecologically and conventionally grown wheat. Journal of Cereal Science 27, 199207

JANSMAn, A.J.M.; Verstegen; M.W.A.; Huisman, J.; VAN DEN BerG; J.W.O., 1995. Effects of faba beans (Vicia faba L.) with a low or high content of condensed tannins on the apparent ileal and fecal digestibility of nutrients and the excretion of endogenous protein in ileal digesta and feces of pigs. Journal of Animal Science 73, 118-127

Jeroch, H.; Flachowsky, G.; Weissbach, F., 1993. Futtermittelkunde. Gustav Fischer Jena Stuttgart

JoHANSEN, H.N. \& BACH KNUDSEN, K.E., 1994. Effects of wheat flour and oat mill fractions of jejunal flow, starch degradation and adsorption of glucose over an insulated loop of jejunum in pigs. British Journal of Nutrition 72, 299-313

Johansen, H. N.; Bach Knudsen, K.E.; SAndströM, B.; Skjøth, F., 1996. Effects of varying content of soluble dietary fibre from wheat flour and oat milling fractions on gastric emptying in pigs. British Journal of Nutrition. 75, 339-351

JongBloED, A.W. \& Mroz, Z., 1997. Intestinal adsorption and secretion of minerals along the digestive tract of pigs. In: LAPlace, J.P.; FÉVRIER, C.; BARBEAU, A. (Eds.), Digestive physiology in pigs. INRA, Paris, France, 288-299

Kestling, U.; Schnabel, E.; Bolduan, G., 1991. Zur Dickdarmkapazität der Sau. In: KiRCHGESSNER, M. (Ed.), Verdauungsphysiologie des Dickdarms. Fortschritte in der Tierphysiologie und Tierernährung 22, Verlag Paul Parey, Hamburg, Berlin, 84-88

KIEFFER, M., 1995. Untersuchungen zur Unterscheidbarkeit von Weizen aus ökologischem und konventionellem Anbau. Dissertation, Universität Bonn

KLEIN, J.,1968. Der Einfluss verschiedener Düngungsarten in gestaffelter Dosierung auf Qualität und Haltbarkeit pflanzlicher Produkte. Institut für Biologisch-Dynamische Forschung Darmstadt

Kroyer, G.T.; Hammerschmidt, V.; WashÜtTl, J., 1995. Bioavailability of mineral substances and trace elements in the presence of dietary fibre. Deutsche Lebensmittel Rundschau 91 (9), 289-291

LoftField, N. \& BeEse, F., 1999. $\mathrm{HNO}_{3}$ Druckaufschlüsse: Eine brauchbare Methode zur ökochemischen Charakterisierung von Böden. unpublished 
Low, A.G., 1989. Secretory response of the pig gut to non-starch polysaccharides. Animal Feed Science and Technology 23, 55-65

Low, A.G., 1990. Nutritional regulation of gastric secretion, digestion and emptying. Nutritional Research Reviews 3, 229-252

KumPulainen, J., 2001. Nutritional and toxicological quality comparisons between organically and conventionally grown foodstuffs. Proceedings / International Fertilizer Society No. 472

MølgaARD, J.P., 2000. Nutrients, secondary metabolites and foreign compounds in organic foods. In: Alföldi, T.; Lockeretz, W.; Niggli, U. (Eds.), Proceedings 13th International IFOAM Scientific Conference, S. 313

NATURLAND, 2002. Naturland Richtlinien. www.naturland,de/n2/Naturland\%20Richtlinie_Juli2002_III.pdf

Naumann, C. \& BASsler, R., 1976-1997. Die chemische Untersuchung von Futtermitteln, Methodenbuch, Vol III with Supplements 1983, 1988 und 1993, loose leave collection. Darmstadt, VDLUFA-Verlag

PetTERSON, B.D., 1982. Konventionell und biologisch dynamisch erzeugte pflanzliche Nahrungsstoffe im Vergleich. Angewandte Wissenschaften. 263, 218-228

Potkins, Z.V. LAwrence, T.L.J.; ThOMLinson, J.R., 1991. Effects of structural and nonstructural polysaccharides in the diet of growing pigs on gastric emptying rate and rate of passage of digesta to the terminal ileum and through the total gastrointestinal tract. British Journal of Nutrition 65, 391-413

RAuPP, J.; REEnTS, H.J.; BACHINGER, J., 1994. Ertrag und Qualität von Sommerweizen bei organischer und mineralischer Düngung an einem trocken-warmen Standort. Mitteilungen der Gesellschaft für Pflanzenbauwissenschaften 7, 253-256

READ, N.W. \& EASTWOOD, M.A., 1992. Gastrointestinal physiology and function. In: Dietary fibre: A component of food: Nutritional function in health and desease. ILSI Human Nutrition Reviews. SCHWEIZER \& EDWARDS (Eds.), Springer-Verlag, London, $103-117$

Rossander, L.; SANDBerg, A.-S.; SAndSTRÖM, B., 1992. The influence of dietary fibre on mineral adsorption and utilization. In: SCHWEIZER, T.F. \& EDWARDS, C.A. (Eds.), Dietary fibre: A component of food: Nutritional function in health and desease. ILSI Human Nutrition Reviews. Springer-Verlag, London, 197-216

Scheller, E., 1999. Proteinqualität bei Weizen, Dinkel und Einkorn. In: HoffmanN, H. \& MÜLLER, S. (Eds.), Beiträge zur 5. Wissenschaftstagung zum ökologischen Landbau, Humboldt Universität Berlin, 121-125

WiSKER, E.\& FELDHEIM, W., 1992. Faecal bulking and energy value of dietary fibre. In: SCHWEIZER, T.F. \& EDWARDS, C.A. (Eds.), Dietary fibre: A component of food: Nutritional function in health and desease. ILSI Human Nutrition Reviews. SpringerVerlag, London, 233-246 
Woese, K.; Lange, D.; Boess, C.; BöGl, K.W., 1995. Ökologisch und konventionell erzeugte Lebensmittel im Vergleich. Eine Literaturstudie. Teil I+II, BGVV Heft 5, Bundesinstitut für gesundheitlichen Verbraucherschutz und Veterinärmedizin, Berlin.

Woese, K.; Lange, D.; Boess, C.; Bögl, K.W., 1997. A comparison of organically and conventionally grown foods- results from a review of the relevant literature. Journal of the Science of Food and Agriculture 74, 281-293

Wolfson, J.L. \& SHEARER, G., 1981. Amino acid composition of grain protein of maize grown with or without pesticides and standard commercial fertilizers. Agronomy Journal 73, 611-613 


\section{General Discussion}

The present study includes analyses of plant composition of organically and conventionally produced cereal and faba bean cultivars, and metabolic trials with pigs of different genetic origins to investigate the influence of fiber rich feedstuff as common in organic farming on nutrient digestibility and balances. Additionally, intestine physiological studies using the Cositec procedure and microcalorimetry to determine intestinal microbial activity as well as mucosal transport processes were carried out.

For the first time a relatively high number of samples of exactly specified cereal and faba bean cultivars, grown under comparably controlled growing conditions from different sites in Germany were analyzed for their nutrient content. Organically produced cereals showed lower crude protein but elevated levels of carbohydrates and fiber fractions, which is in agreement with other studies (ANDERSEN et al., 2001; DlOUHY, 1981; GRANSTED \& KJellenberG, 1996; Haglund, 1998; KiefFer, 1995; Kumpulainen, 2001; Ministerium FÜR ERNÄHRUNG, LANDWIRTSCHAFT UND UMWELT BADEN-WÜRTTEMBERG, 1977; Mølgaard, 2000; Petterson, 1982; Raupp et al, 1994; Shier et al., 1984; Woese et al., 1995, 1997). Organically cultivated faba beans showed similar tendencies for crude protein and fiber, with changes in NDF and ADF being different from those observed in cereals. In contrast to cereals, starch content was significantly lower in organic faba beans. These results indicate no trend for higher biological value in organic cereals and faba beans. Furthermore it is assumed that organically produced faba beans contain lower levels of metabolizable energy $\left(\mathrm{MJ} \mathrm{ME}_{\mathrm{BFS}} / \mathrm{kg}\right.$ ) than conventionally grown ones. However, studies on nutrient composition in organically and conventionally produced cereals and faba beans of the same cultivars grown under the same conditions should be pursued further.

Differences observed in fiber contents of organically and conventionally produced plants were investigated regarding their nutritive value. This was achieved using two diets containing different amounts of fiber having some kind of model character, which allowed for estimating the capacity for fiber digestion in different breeds of pigs. From this, conclusions may be drawn on the suitability of specific pig breeds in organic farming.

Sugar beet pulp, which was used as fiber source, contains high levels of $\beta$-glycosidic, nonlignified, soluble non-starch polysaccharides. Different pig breeds were selected based on assumed differences in their ability for fiber fermentation as a result of the breeding process.

Fiber additions were highly digestible but caused lower digestibilities in all other nutrients. They also resulted in partial redistribution of $\mathrm{N}$-excretions from urine to feces, which would 
be judged positive in organic farming. The fiber-linked change in the pattern of N-excretion is in accordance with results achieved by BACH KNUDSEN et al. (1993a), BACH KNUDSEN et al. (2000); Boisen \& FernÁndes (1995), Kreuzer et al. (1991), Kreuzer et al. (1999), De LANGe et al. (1990), Drochner (1984), Furda (1990), GALIBOIS et al. (1994), Le GoFf et al. (2000), LeTERme et al. (2000), Mosenthin et al. (1992), Mroz et al. (2000), RAMONET et al. (1999) and ZERVAS\& ZIJLSTRA (2003). Lower digestibilities were also observed when pigs were fed the organic compared to the conventional diets. Beside the elevated fiber content in the organic diet, the use of faba beans compared to soybean meal and cereals in the conventional diet influences nutrient digestibilies. Results indicate generally lower digestibilities of organic diets. On the other hand, nitrogen and mineral retentions were increased with fiber-rich feeding. Whether the retained $\mathrm{N}$ was a gain in body weight or merely a fiber-related increase in N-content in the digestive tract should be studied further.

The three breeds differed in their ability to digest fiber. However there is no clear indication for higher fiber degradation in old pig breeds compared to their modern counterparts. SH showed even lower fiber digestion than $\mathrm{CB}$, even though they were expected to have a reduced capacity for fiber degradation caused by the selection process. The results of the in vivo experiments are confirmed by results on fermentation capacity achieved with the in vitro experiments using the COSITEC system and by the results of the microcalorimeter experiments. On the other hand Cositec experiments did not show lower fermentation potential in SH pigs. These apparent contradictory results can be explained by different fermentative properties of intestine content used in COSITEC, which must have been due to different precaecal digestive processes in the pigs, despite the fact that samples of caecum content were taken at the exact same time after feeding.

There are indications that soluble NSP may have been already digested to a greater extent prior to entering the caecum and colon of pigs. GRAHAM et al. (1986) found that on average $44 \%$ of NSP in sugar beet pulp is degraded prior to the terminal ileum. However, the results show, that the amount of precaecally-digested fiber must have differed between the breeds. Possible causative factors are morpho-and histophysiological differences like intestine length, amount and expression of microvilli and secretory activity, as well as intestine motility and digesta passage influencing factors (DERSJANT et al., 2001; EDWARDS, 1990; FLOURIÉ, 1992; FURDA, 1990; JøRGENSEN et al., 1996; JOHANSEN et al., 1996; LOW, 1989; MIQUEL et al., 2001; 1986; ZHAO et al., 1995). Measurements of membrane function and transportphysiology in jejunal mucosa show the same tendency. If differences in intestinal transport 
physiology caused by diet or breed are a result of changes in carrier expression or their affinity need to be investigated in further experiments.

The results further show, that soluble NSP strongly influence digestive processes already in the small intestine. To what extent soluble NSP do have an effect on animal health and nutrient utilization must be a cause for futher studies.

Alltogether, there is no physiological background for a general preference of old breeds in organic pig production. Greatest differences in fiber digestion occured between the two old local breeds, and the modern crossbreed exhibitted a similar potential for fiber digestion as one of the old breeds. Results of the present investigation may serve as a first step in further specifying organic versus conventional feedstuff as well as elucidating their fiber-related effects on digestive physiology in pigs 


\section{Summary}

A total of 56 samples representing 14, 4 and 6 different cultivars of wheat, faba beans and barley, each of conventional and organic cultivation of the same location (4 locations in Germany) and year, were analyzed for their nutrient contents. In wheat, crops grown organically showed significantly reduced content of crude protein, whereas starch and fiber content tended to be increased. Organically grown barley tended toward significantly lower protein and higher starch content than conventionally grown cultivars. Fiber content was similarly increased. In faba beans the content of crude protein and fiber was affected by organic farming in the same manner as the cereal cultivars. The content of starch was also significantly reduced.

Assuming that organic feeding results in an elevated supply of fiber, 2-factorial experiments with three different breeds, (Schwäbisch-Hällisches Schwein (SH), Buntes Bentheimer Schwein (BB) and modern crossbreed pig (CB)) and two different diets (basal diet (BD) and basal diet + sugar beet pulp (SBP)) were carried out in order to study fiber-related digestive processes. The basal diet was calculated to meet $80 \%$ of energy and $100 \%$ of amino acid requirements for average daily body weight gains of $700 \mathrm{~g} / \mathrm{d}$. Pigs had average bodyweights of $35-40 \mathrm{~kg}$ and were first used for metabolic trials. Thereafter, pigs were slaughtered and their caecum contents used for the Colon Simulation Technique (COSITEC) and for microcalorimeter experiments. Samples of jejunum and colon mucosa were taken for the measurement of electrophysiological transport parameters according to the Ussing-Chamberprocedure.

The supplementary fiber of SBP, essentially consisting of unlignified soluble non-starch polysaccharides, was highly digestible whereas the digestibilities of all other nutrients were significantly reduced after feeding the SBP-diet. Urine $\mathrm{N}$ was reduced and fecal $\mathrm{N}$ increased with the fiber rich diet. Compared to the BD-fed group, caecum contents taken from SBP-fed pigs led to higher fermentation intensity in the COSITEC and higher microbial activity in microcalorimeter experiments. $\mathrm{N}$ - and mineral-retentions $(\mathrm{Ca}, \mathrm{Mg}, \mathrm{Na}, \mathrm{K})$ of the pigs were also increased after feeding the SBP-diet.

The ability to digest high fiber feedstuffs differed among the three breeds being used. However, there was no clear indication for higher fiber degradation in the old pig breeds, with SH showing a lower digestion than $\mathrm{BB}$ and $\mathrm{CB}$.

The results on digestive physiology as well as those on electrophysiological mucosal membrane transport indicate significant influences of soluble NSP and pig breed on precaecal digestive processes. Specific investigations are necessary to clarify their impact for intestinal nutrient utilization and animal health.

In order to investigate the influence of organic diets on digestive processes an additional 2factorial experiment with two different breeds, Buntes Bentheimer Schwein (BB) and modern crossbreed pig (CB)) and two different diets (conventional diet (CD) and organic diet (OD)) was carried out as a metabolic trial.

Feeding the OD resulted in significantly reduced digestibilities for nearly all nutrients, except for ether extract and NfE. N- and mineral retentions were not significantly influenced by the diet. Only phosphorous retention was clearly reduced with feeding the OD. BB pigs showed higher nutrient digestibilities compared to $\mathrm{CB}$ pigs when the organic diet was fed.

These results together with those achieved for the SBP addition indicate significant influences of the nutrition on digestive physiology, which are very different between the pig breeds. It must be theme of further investigations, how strong the impact of both, a fiber addition combined with factors being associated with organic diets, is on digestive processes, to draw valid conclusions on the suitability of certain pig breeds for organic farming. 


\section{Zusammenfassung}

Es wurden an insgesamt 56 Proben bestehend aus 14 Weizen-, 6 Gerste- und 4 Ackerbohnensorten, die im gleichen Jahr an verschiedenen Standorten in Deutschland entweder nach Richtlinien des ökologischen Landbaus oder konventionell angebaut worden waren, Nährstoffanalysen durchgeführt. Im Vergleich zum konventionellen Anbau führte der ökologische Anbau bei Weizen zu signifikant niedrigeren Gehalten an Rohprotein (XP) sowie zu tendenziell höheren Gehalten an Stärke und Faserstoffen. Nach ökologischen Richtlinien angebaute Gerste wies signifikant niedrigere Gehalte an Rohprotein, signifikant höhere Gehalte an Stärke und tendenziell gesteigerte Faserstoffgehalte auf. Bei Ackerbohnen ergaben sich für Rohprotein und Faserstoffe tendenziell ähnliche Veränderungen wie beim Getreide, die Stärkegehalte wurden bei ökologischer Anbauweise signifikant gesenkt.

Von einer grundsätzlich faserreicheren Fütterung im ökologischen Landbau ausgehend, wurden in zweifaktoriellen Stoffwechselversuchen an drei verschiedenen genetischen Schweineherkünften (Schwäbisch Hällisches Schwein (SH), Buntes Bentheimer Schwein (BB) und einer modernen fleischbetonten Gebrauchskreuzung (CB)) mit zwei Futterrationen (Grundration und Grundration + Zuckerrübentrockenschnitzel) im Lebendmassebereich von 35 - $40 \mathrm{~kg}$ faserbezogene Verdauungsprozesse untersucht. Die Zumessung der Grundration erfolgte so, dass für durchschnittliche tägliche Zunahmen von $700 \mathrm{~g}$ der Energiebedarf der Schweine zu 80\% und der Aminosäurenbedarf zu 100\% gedeckt wurde. Die Schweine standen zunächst in Stoffwechselversuchen. Nach deren Ende wurden die Schweine geschlachtet und der Caecuminhalt zur Verwendung in der Colon-Simulationstechnik COSITEC sowie für Mikrokalorimeterexperimente entnommen. Mucosaproben des mittleren Jejunums sowie des Colon dienten für transportphysiologische Messungen mittels des UssingKammer-Verfahrens.

Die Faserzulage, die dem Typ der nicht lignifizierten löslichen NSP zuzuordnen ist, war hoch verdaulich und bewirkte niedrigere Verdaulichkeiten aller übrigen Nährstoffe. Die NAusscheidungen über den Harn wurden vermindert und die über den Kot gesteigert. Die Fermentationsintensität stieg in der Colon-Simulation sowie in den Mikrokalorimeterexperimenten bei Verwendung des Caecuminhalts faserreich gefütterter Schweine. Die Nund Mineralstoffretentionen $(\mathrm{Ca}, \mathrm{Mg}, \mathrm{Na}, \mathrm{K}$ ) nahmen bei faserreicher Fütterung $\mathrm{zu}$.

Die drei Schweineherkünfte unterschieden sich in ihrem Faserverdauungsvermögen. Es zeigte sich jedoch keine generelle Überlegenheit der beiden alten Landrassen gegenüber der modernen Gebrauchskreuzung. Die Schwäbisch-Hällischen Schweine verdauten signifikant weniger Faser als die Bunten Bentheimer und die Gebrauchskreuzungen. Aufgrund der verdauungs- und transportphysiologischen Messungen waren für die Unterschiede im Faserverwertungsvermögen der drei Schweineherkünfte vor allem precaecale Verdauungsprozesse ausschlaggebend, deren Wirkungsweisen und Konsequenzen für die Nährstoffverwertung und Tiergesundheit weiter erforscht werden müssen.

Um zusätzlich den Einfluss ökologischer Futterrationen auf die Verdauungsprozesse zu untersuchen, wurden in einem ergänzenden, ebenfalls zweifaktoriell aufgebauten Stoffwechselversuch zwei Rationen (konventionelle Ration (CD) und ökologische Ration $(\mathrm{OD})$ ) und zwei verschiedene Schweineherkünfte (Buntes Bentheimer Schwein (BB) und eine moderne fleischbetonte Gebrauchskreuzung (CB)) getestet.

Die Fütterung der OD bewirkte reduzierte Verdaulichkeiten aller Nährstoffe, mit Ausnahme von Rohfett und NfE. N- und Mineralstoffretentionen waren nicht signifikant durch die Rationen beeinflusst. Lediglich die Phosphorretention war durch ökologische Fütterung signifikant reduziert. BB Schweine zeigten erhöhte Nährstoffverdaulichkeiten bei Fütterung der ökologischer Ration im Vergleich zu den CB Schweinen. 
Diese Ergebnisse zeigen gemeinsam mit denen des Zulageversuchs signifikante Einflüsse der Fütterung auf die Verdauungsprozesse, die zwischen den verschiedenen Schweinerassen variieren. Weitere Untersuchungen sind notwendig, um Rückschlüsse auf den Einfluss einer Kombination aus faserreicher Fütterung und mit der Fütterung ökologischer Rationen assoziierter Faktoren auf Verdauungsprozesse und damit die Eignung bestimmter Schweinerassen für den ökologischen Landbau ziehen zu können. 


\section{References: Introduction and Literature review and General discussion}

ALFÖLDI, T, 1998. Vergleichende Qualitätsuntersuchungen zwischen biologisch und konventionell angebauten Produkten: Eine kritische Betrachtung der Forschungsarbeiten zwischen 1993 und 1998. Forschungsinstitut für ökologischen Landbau, Frick, Schweiz

Andersen, J.-O.; O`Doherty Jensen, K.; Larsen, H.N.; Mølgaard, J.P., Tingstad, A.; MARCKMANN, P.; AstruP, A., 2001. Organic foods and human health. Proceedings of the European conference: Organic Food and Farming, Copenhagen, 172-177

Anderson, J.W. \& SieSEl, A.E., 1990. Hypocholesterolemic effects of oat products. In: FURDA, I. \& BRINE, C.J. (Eds.), New developments in dietary fiber: physiological, physiochemical and analytical aspects. Advances in experimental medicine and biology, Vol.270, Plenum Press, New York, London, 17-36

Bach Knudsen, K.E.\& HAnsen, I., 1991. Gastrointestinal implications in pigs of wheat and oat fractions. 1. Digestibility and bulking properties of polysaccharides and other major constituents. British Journal of Nutrition 65, 217-232

Bach Knudsen, K.E.; Jensen, B.B.; Andersen, J.O.; Hansen, I, 1991. Gastrointestinal implications in pigs of wheat and oat fractions. 2. Microbial activity in the gastrointestinal tract. British Journal of Nutrition 65, 233-248

Bach Knudsen, K.E.; Jensen, B.B.; Hansen, I., 1993a. Oat bran but not a B-Glucanenriched oat fraction enhances butyrate production in the large intestine of pigs. Journal of Nutrition, 1235-1247

Bach KnUdsen, K.E.; Jensen, B.B ; Hansen, I., 1993b. Digestion of polysaccharides and other major components in the small intestine of pigs fed on diets consisting of oat fractions rich in B-D-Glucan. British Journal of Nutrition 70, 537-556

BACH KnUdSEN, K.E., 1997. Carbohydrate and lignin contents of plant material used in animal feeding. Animal Feed Science and Technology 67, 319-338

BACH KnUdsen, K.E. \& CANiBE, N., 2000. Breakdown of plant carbohydrates. Journal of the Science of Food and Agriculture 80, 1252-1261

BACH KNUdSEN, K.E.; JøRGENSEN, H.; CANIBE, N., 2000. Quantification of the adsorption of nutrients derived from carbohydrate assimilation: model experiment with pigs fed wheat or oat based rolls. British Journal of Nutrition 84 (4), 449-458

BakKer, G.C.M.; BaKker, J.G.M.; DekKer, R.A.; Everts, H.; Jongbloed, Van Der MeulEN, J.; LENIS, N.P., 1996. The quantitative relationship between absorption of nitrogen and starch from the hindgut of pigs. Journal of Animal Sciences 74, 188A

BaKker, G.C.M; DekKer, R.A.; Jongbloed, R.; Jongbloed, A.W., 1998. Non-starch polysaccharides in pig feeding. Veterinary-Quarterly. 20 (3), 59-64 
BeAmes, R.M. \& EgGuM, B.O., 1981. The effect of type and level of protein, fibre and starch on nitrogen excretion patterns in rats. British Journal of Nutrition 46, 301-313

BEHALL, K.M., 1990. Effect of soluble fibers on plasma lipids, glucose tolerance and mineral balance. In: FURDA, I. \& BRINE, C.J. (Eds.), New developments in dietary fiber: physiological, physiochemical and analytical aspects. Advances in experimental medicine and biology, Vol.270, Plenum Press, New York, London

Bergner, H. \& Tegtmeier, B., 1985. Beziehungen zwischen der ${ }^{15} \mathrm{~N}$-Exkretion über den Kot nach oraler ${ }^{15} \mathrm{~N}$-Harnstoffaufnahme und der Blutharnstoffkonzentration in Abhängigkeit von der Rohfaseraufnahme bei Schweinen. Archiv für Tierernährung 35 (8), 535-543

BINGHAM, S.A., 1990. Mechanism and experimental epidemiological evidence relating dietary fiber (non starch polysaccharides) and starch to protection against large bowel cancer. Proceedings of the Nutrition Society. 49, 153-171

BIOLAND, 2001. Bioland Richtlinien, www.bioland.de/bioland/richtlinien/erzeugerrichtlinien.pdf, March 2004

BoISEN, S. \& FERNÁNDES, J.A., 1995. Prediction of the apparent ileal digestibility of protein and amino-acids in feedstuffs and feed mixtures for pigs by in vitro analyses. Animal Feed Science and Technology 51, 29-43

Bolduan, G.; Schnabel, E.; BeCK, M., 1991. Fermentierungseffekte in Dickdarmabschnitten beim Schwein. In: KIRCHGESSNER, M. (Ed.), Verdauungsphysiologie des Dickdarms. Fortschritte in der Tierphysiologie und Tierernährung 22, Verlag Paul Parey, Hamburg, Berlin, 80-83

Bolling, H.; Gerstenkorn, P.; WeiPert, D., 1986. Vergleichende Untersuchungen zur Verarbeitungsqualität von alternativ und konventionell angebautem Brotgetreide. Getreide, Mehl und Brot 40 (2), 46-51

BRAND, K. \& MølgaARD, J.P., 2001. Organic agriculture: does it enhance or reduce the nutritional value of plant foods. Journal of Science of Food and Agriculture 81, 924931

BUNDESMINISTERIUM FÜR VERBRAUCHERSCHUTZ, ERNÄHRUNG UND LANDWIRTSCHAFT, 2004. Verordnung (EWG) Nr. 2092/91 (EG-Öko-Verordnung) und Folgerecht. www.verbraucherministerium.de/indexCC50A5785E6947818086B26C12A90287.html

CAmeron, I.L.; Hardman, W.E.; Heitman, D.W.; CARTER, J.W., 2000. Dietary fibre on cell proliferation in large bowel mucosal crypts near or away from lymphoid nodules and on mineral bioavailability. Cell Proliferation 33(6), 367-379

CANiBE, N. \& BACH KNUdSEN, K.E., 2001. Degradation and physicochemical changes of barley and pea fibre along the gastrointestinal tract of pigs. Journal of the Science of Food and Agriculture 82, 27-39 
CARlson, D.; Laerke, H.; Poulsen, H.; Jørgensen, H, 1999. Roughages for growing pigs, with emphasis on chemical composition, ingestion and faecal digestibility. Acta Agriculturae Scandinavica, Sect. A Animal Science (3), 129-136

Chabeauti, E.; Noblet, J; CarRé, B., 1991. Digestion of plant cell walls from four different sources in growing pigs. Animal Feed Science and Technology 32, 207-213

Christensen, D.N.; Bach Knudsen, K.E.; Wolstrup, J.; Jensen, B.B., 1999. Integration of ileum cannulated pigs and in vitro fermentation to quantify the effect of diet composition on the amount of short-chain fatty acids available from fermentation in the large intestine. Journal of the Science of Food and Agriculture 79, 755-762

DANIELSEN, V., 2000. Svinenes forsyning med essentielle næringsstoffer og grovfoder. In: HERMANSEN, J.E. (Ed.). Økologisk svineproduktion. Udfordringer, muligheder og begrænsninger. FØJO rapport 8, 95-119

DANIELSEN, V., 2001. Essentielle næringsstoffer og grovfoder i økologisk svineproduktion. Forskningsnytt om økologisk landbruk i norden 1, www.forskningsnytt.org, July 2002

De Lange, C.F.M.; Souffrant, W.B.; SAuER, W.C., 1990. Real ileal protein and amino acid digestibilities in feedstuffs for growing pigs as determined with the ${ }^{15} \mathrm{~N}$-Isotope dilution technique. Journal of Animal Science 68, 409-418

Delgado, E.; MöLler, K.; PAWELZIK, E., 1999. Influence of nitrogen Fertilization on protein quality of rye and oat grains. Agribiological Research 52, 337-345

DEMETER, 2002. Richtlinien Erzeugung. www.demeter.de/demeter/dem_richtlinien.pdf, March 2004

Demeyer, D.I.; Vande Woestyne, M.; Prins, R.; 1995 Mikrobiologie der Verdauung.. In: ABel, HJ.; Flachowsky, G.; Jeroch, H.; Molnar, S. (Eds.), Gustav Fischer Verlag, Jena, Stuttgart, 185-205

Dersuant-Li, Y.; Verstegen, M.W.; Schulze, H.; Zandstra, T.; Boer, H.; Schrama, J.W; VERRETH, J.A., 2001. Performance, digesta characteristics, nutrient flux, plasma composition, and organ weight in pigs as affected by dietary cation anion difference and nonstarch polysaccharide. Journal of Animal Science 79 (7), 1840-1848

DLOUHY, J., 1981. Alternativa odlingsformer-växtprodukters kvalität vid konventionell och biodynamisk odling, Sveriges Lantbruksuniversitet, Institut för växtodling, Rapport 91, Uppsala

Drochner, W., 1984. Einfluß wechselnder Rohfaser und Pektingehalte im Futter auf präcaecale und postileale Verdauungsvorgänge beim wachsenden Schwein. Fortschritte in der Tierphysiologie und Tierernährung 14, Verlag Paul Parey, Hamburg, Berlin

EDWARDS, C., 1990. Mechanisms of action of dietary fibre on small intestine adsorption and motility. In: FURDA, I. \& BRINE, C.J. (Eds.), New developments in dietary fibre: physiological, physiochemical and analytical aspects. Advances in experimental medicine and biology, Vol.270, Plenum Press, New York, London 
EGGuM, B.O., 1992. The influence of dietary fibre on protein diestion and utilisation. In: SCHWEIZER, T.F. \& EDWARDS, C.A. (Eds.), Dietary fibre: A component of food: Nutritional function in health and desease., ILSI Human Nutrition Reviews, SpringerVerlag, London, 153-166

Eggum, B.; Thorbek, G.; Beames, R.M.; Chwalibog, A.; Henckel, S., 1982. Influence of diet and microbial activity in the digestive tract on digestibility, and nitrogen and energy metabolism in rats and pigs. British Journal of Nutrition 48, 161-175

Flourié, B., 1992. Influence of dietary fibre on carbohydrate digestion and adsorption. In: SCHWEIZER, T.F. \& EDwardS, C.A. (Eds.), Dietary fibre: A component of food: Nutritional function in health and desease., ILSI Human Nutrition Reviews, SpringerVerlag, London, 181-196

Freire, J.P.B.; Guerreiro, A.J.G.; CunHA, L.F.; Aumaitre, A., 2000. Effect of dietary fibre source on total tract digestibility, caecum volatile fatty acids and digestive transit time in the weaned piglet. Animal Feed Science and Technology 87, 71-83

FrøLICH, W., 1990. Chelating properties of dietary fiber and phytate. The role for mineral availability. In: FURDA, I. \& BRINE, C.J. (Eds.), New developments in dietary fibre: physiological, physiochemical and analytical aspects. Advances in experimental medicine and biology, Vol.270, Plenum Press, New York, London

FURDA, J., 1990. Interaction of dietary fibre with lipids-mechanistic theories and their limitations. In: FURDA, I. \& BRINE, C.J. (Eds.), New developments in dietary fibre: physiological, physiochemical and analytical aspects. Advances in experimental medicine and biology, Vol.270, Plenum Press, New York, London, 67-82

Galibois, I.; Desrosiers, T.; Guevin, N.; Lavigne, C.; Jaques, H., 1994. Effects of dietary fibre mixtures on glucose and lipid metabolism and on mineral adsorption in the rat. Annals of nutrition and metabolism 38 (4), 203-211

Govers; M.G.; Gannon, N.J.; Dunshea, F.R.; Gibson, P.R., Muir, J.G., 1999. Wheat bran affects the site of fermentation of resistant starch and luminal indexes related to colon cancer risk: a study in pigs. Gut 45 (6), 840-847

Graham, H.; Hesselman, K.; Åman, P., 1986. The influence of wheat bran and sugar-beet pulp on digestibility of dietary components in a cereal -based pig diet. Journal of Nutrition 116, 242-251

Gransted, A.G.\& KJellenBerG, L., 1996. Quality investigations with the K-trial Järna, and other Scandinavian fertilization experiments. In: RAUPP, J.(Ed.). Quality of plant products grown with manure fertilization: Fertilization systems in organic farming. (Concerted action AIR3-CT94-1940) Meeting Juva, Finland, 1996, 3-12

Haglund, Å.; JohAnsson, L.; DAhlstedT, L., 1998. Sensory evaluation of wholemeal bread from ecologically and conventionally grown wheat. Journal of Cereal Science 27, 199207 
HERMANSEN, J.E., 2000. Økologisk svineproduktion. Udfordringer, muligheder og begrænsninger. FØJO rapport 8

Hoebler, C.; Guillon, F.; FARdet, A.; Cherbut, C., 1998. Gastrointestinal or simulated in vitro digestion changes dietary fibre properties and their fermentation. Journal of Science of Food and Agriculture 77, 327-333

JENSEN, B.B. \& JøRgensen, H., 1994. Effect of dietary fibre on microbial activity and microbial gas production. Applied and Environmental Microbiology 60, 1897-1904

Jeroch, H.; Drochner, W.; Simon, O., 1999. Ernährung landwirtschaftlicher Nutztiere. Verlag Eugen Ulmer, Stuttgart

Johansen, H. N.; Bach Knudsen, K.E.; SAndströM, B.; Skjøth, F., 1996. Effects of varying content of soluble dietary fibre from wheat flour and oat milling fractions on gastric emptying in pigs. British Journal of Nutrition. 75, 339-351

JoHANSEN, H.N. \& BACH KNUDSEN, K.E., 1994. Effects of wheat flour and oat mill fractions of jejunal flow, starch degradation and adsorption of glucose over an insulated loop of jejunum in pigs. British journal of Nutrition 72, 299-313

JoHnSON, I.T., 1992. The influence of dietary fibre on lipid digestion and adsorption. In: SchweIZER, T.F. \& EDWARDS, C.A. (Eds.), Dietary fibre: A component of food: Nutritional function in health and desease. ILSI Human Nutrition Reviews., SpringerVerlag, London, 167-180

JongBloed, A.W. \& Mroz, Z., 1997. Intestinal adsorption and secretion of minerals along the digestive tract of pigs. In: LAPlace, J.P.; FÉVrier, C.; Barbeau, A. (Eds.), Digestive physiology in pigs. INRA, Paris, France, 288-299

Jørgensen, H.; ZhaO, X.-Q.; Eggum, B., 1996. The Influence of dietary fibre and environmental temperature on the development on the gastrointestinal tract, digestibility, degree of fermentation in the hindgut and energy metabolism in pigs. British Journal of Nutrition 75, 365-378

Jørgensen, H.; Larsen, T.; ZhaO, X.-Q.; EgGum, B.O., 1997. The energy value of shortchain fatty acids infused into the caecum of pigs. British Journal of Nutrition 77, 745756

Jørgensen, H.; Bach KnUdSen, K.E.; Jørgensen, H., 2001. Effect of dietary fibre on energy metabolism of growing pigs and pregnant sows. In: CHWALIBOG, A.; JAKOBSEN, K. (Eds.) Energy metabolism in animals. EAAP publication 103 (Wageningen press), 105-108

Kestling, U.; Schnabel, E.; Bolduan, G., 1991. Zur Dickdarmkapazität der Sau. In: KirChgessner, M. (Ed.), Verdauungsphysiologie des Dickdarms. Fortschritte in der Tierphysiologie und Tierernährung 22, Verlag Paul Parey, Hamburg, Berlin, 84-88

KIEFFER, M., 1995. Untersuchungen zur Unterscheidbarkeit von Weizen aus ökologischem und konventionellem Anbau. Dissertation, Universität Bonn 
KLEIN, J., 1968. Der Einfluss verschiedener Düngungsarten in gestaffelter Dosierung auf Qualität und Haltbarkeit pflanzlicher Produkte. Institut für Biologisch-Dynamische Forschung Darmstadt

KreuZER, M.; KIRCHGESSNER, M.; Roth, F.X., 1991. Experimental evaluation of the capacity of the hindgut of sows to ferment purified dietary ingredients and of consequences in nitrogen metabolism. In: KIRCHGESSNER, M. (Ed.), Verdauungsphysiologie des Dickdarms. Fortschritte in der Tierphysiologie und Tierernährung 22, Verlag Paul Parey, Hamburg, Berlin, 62-66

Kreuzer, M.; Wittmann, A.; Gerdemann, M.M.; HenneKen, H.; Abel H.J.; MACHMÜLLER, A., 1999. Re-examination of the metabolizable energy contents of various rations containing different types and levels of bacterially fermentable substrates in digestibility experiments with growing pigs. Journal of Animal Physiology and Animal Nutrition 82, 33-49

Kroyer, G.T.; HAMmerschmidt, V.; WashÜTtL, J., 1995. Bioavailability of mineral substances and trace elements in the presence of dietary fibre. Deutsche Lebensmittel Rundschau 91 (9), 289-291

Kumpulainen, J., 2001. Nutritional and toxicological quality comparisons between organically and conventionally grown foodstuffs. Proceedings / International Fertilizer Society No. 472

Le Goff, G. \& Noblet, J., 2001. Comparative tract digestibility of dietary energy and nutrients in growing pigs and adult sows. Journal of Animal Science 79, 2418-2427

Le Goff, G.; Le Groumellec, L.; Van Milgen, J.; Dubois, S.; Noblet, J., 2002. Digestibility and metabolic utilization of dietary energy in adult sows. Influence of addition and origin of dietary fibre. British Journal of Nutrition 87, 325-335

Leterme, P.; Souffrant, W.-B.; THÉWIS, A., 2000. Effect of barley fibres and barley intake on the endogenous nitrogen losses in piglets. Journal of Cereal Science 31, S. 229-239

Low, A.G., 1990. Nutritional regulation of gastric secretion, digestion and emptying. Nutritional Research Reviews 3, 229-252

MAdAR, Z. \& OdeS, H.S., 1990. Dietary fibre research. Progress in Biochemical Pharmacology Bd.24, Karger Verlag

Michel, P. \& RÉRAT, A., 1998. Effect of adding sugar beet fibre and wheat bran to a starch diet on the adsorption kinetics of glucose, amino-nitrogen and volatile fatty acids in the pig. Reproduction Nutrition Development 38, 49-68

Millard, P. \& Chesson, A., 1984. Modifications to swede (Brassica napus L.) anterior to the terminal ileum of pigs: some implications for the analysis of dietary fibre. British Journal of Nutrition 52, 583-594

MineO, H.; Hara, H.; TomitA, F., 2001. Short chain fatty acids enhance diffusional Ca transport in the epithelium of the rat cecum and colon. Life Science 88 (3), S. 317-320 
MiNiSTERIUM FÜR ERNÄHRUNG, LANDWIRTSCHAFT UND UMWELT BADEN-WÜRTTEMBERG, 1977. Auswertung dreijähriger Erhebungen in neun biologisch-dynamisch wirtschaftenden Betrieben, Stuttgart

MiQUel, N.; BACH KNUDSEN, K.E.; JøRGENSEN, H., 2001. Impacts of diets varying in dietary fibre characteristics on gastric emptying in pregnant sows. Archiv Tierernährung, 121145

MøLgaARD, J.P., 2000. Nutrients, secondary metabolites and foreign compounds in organic foods. In: Alföldi, T.; LockeretZ, W.; Niggli, U. (Eds.), Proceedings 13th International IFOAM Scientific Conference, 313

Mosenthin, R. \& SAUER, W.C., 1993. Exocrine pancreatic secretions in pigs as influenced by the source of carbohydrate in the diet. Zeitschrift für Ernährungswissenschaft $32(2), 152-155$

Mosenthin, R.; Sauer, W.C.; De LAnge, C.F.M, 1992a. Tracer studies of urea kinetics in growing pigs: The effect of intravenous infusion of urea on urea recycling and the site of urea secretion into the Gastrointestinal tract. Journal of animal science 70, 34583466

Mosenthin, R.; Sauer, W.C.; Henkel, H.; Ahrens, F.; De Lange, C.F.M, 1992b. Tracer studies of urea kinetics in growing pigs: The effect of starch infusion at the distal ileum on urea recycling and bacterial nitrogen excretion. Journal of Animal Science $70,3467-3472$

Mroz, Z.; Moeser, A.J.; Vreman, K.; Van Diepen, J.T.; Van Kempen, T.; Canh, T.T.; JONGBLOED, A.W., 2000. Effects of dietary carbohydrates and buffering capacity on nutrient digestibility and manure characteristics in finishing pigs. Journal of Animal Science 78, 3096-3106

NAGENGAST, F.M., 1992. Dietary fibre and bile acid metabolism. In: SCHWEIZER, T.F. \& EDWARDS, C.A. (Eds.), Dietary fibre: A component of food: Nutritional function in health and desease., ILSI Human Nutrition Reviews, Springer-Verlag, London, 217228

NATURLAND, 2002. Naturland Richtlinien.

www.naturland.de/n2/Naturland\%20Richtlinie_Juli2002_III.pdf

Noblet, J. \& BouRdon, D., 1997. Valeur énérgetique comparée de onze matières premières chez le porc en croissance et la trui adulte. Journées de la Recherche Porcine en France 29, 221-226

Noblet, J. Le GofF, G., 2001. Effect of dietary fibre on energy value of feeds for pigs. Animal feed Science and Technology 90, 35-52

PetTERSON, B.D., 1982. Konventionell und biologisch dynamisch erzeugte pflanzliche Nahrungsstoffe im Vergleich. Angewandte Wissenschaften. 263, 218-228 
Potkins, Z.V. LAWRence, T.L.J.; ThomLinson, J.R., 1991. Effects of structural and nonstructural polysaccharides in the diet of growing pigs on gastric emptying rate and rate of passage of digesta to the terminal ileum and through the total gastrointestinal tract. British Journal of Nutrition 65, 391-413

Ramonet, Y.; Meunier-Salaün, M.C.; Dourmad, J.Y., 1999. High fiber diets in pregnant sows. Digestive utilization and effects on the behavior of the animals. Journal of Animal Science 77, 591-599

Ramonet, Y.; Van Milgen, J.; Dourmad, J.Y.; Meunier-Salaün, M.C.; Noblet, J., 2000. The effect of dietary fibre on energy utilisation and partitioning of heat production over pregnancy in sows. British Journal of Nutrition 84, 85.94

RAuPP, J.; REENTS, H.J.; BACHINGER, J., 1994. Ertrag und Qualität von Sommerweizen bei organischer und mineralischer Düngung an einem trocken-warmen Standort. Mitteilungen der Gesellschaft für Pflanzenbauwissenschaften 7, 253-256

READ, N.W. \& EASTWOOD, M.A., 1992. Gastrointestinal physiology and function. In: Dietary fibre: A component of food: Nutritional function in health and desease. ILSI Human Nutrition Reviews. SchweIzer, T.F. \& Edwards, C.A. (Eds.), Springer-Verlag, London, 103-117

RÉMÉSY, C.; DEMIGNÉ, C.; MoRAND, C., 1992. Metabolism and utilisation of short chain fatty acids produced by colonic fermentation. In: SchweIzER, T.F. \& EDWARDS, C.A. (Eds.), Dietary fibre: A component of food: Nutritional function in health and desease. ILSI Human Nutrition Reviews. Springer-Verlag, London, 137-150

RIJINEN, M.M.J.A, 2001. Effect of dietary fermentable carbohydrates on energy metabolism in group housed pigs. Journal of Animal Science 79, 148-154

Rossander, L.; SAndBerg, A.-S.; SAndSTRÖM, B., 1992. The influence of dietary fibre on mineral adsorption and utilization. In: SchWEIZER, T.F. \& EDWARDS, C.A. (Eds.), Dietary fibre: A component of food: Nutritional function in health and desease. ILSI Human Nutrition Reviews. Springer-Verlag, London, 197-216

Scheller, E., 1999. Proteinqualität bei Weizen, Dinkel und Einkorn. In: HoffmAnN, H. \& MülLER, S. (Eds.), Beiträge zur 5. Wissenschaftstagung zum ökologischen Landbau, Humboldt Universität Berlin, S. 121-125

SCHNEEMAN, B.O., 1990. Gastrointestinal responses to dietary fiber. In: FURDA, I. \& BRINE, C.J. (Eds.), New developments in dietary fibre: physiological, physiochemical and analytical aspects. Advances in experimental medicine and biology, Vol.270, Plenum Press, New York, London, 37-42

Schrama, J.W.; Verstegen, M.W.A.; Verboeket, P.H.J.; Schutte, J.B.; HaAksma, J., 1996. Energy metabolism in relation to physical activity in growing pigs as affected by type of dietary carbohydrate. Journal of Animal Sciences 74, 2220-2225

Schrama, J.W., Bosch, M.W.; Verstegen, M.W.A.; VorselaArs, A.H.P.M.; HaAKsma, J; HEETKAMP, M.J.W., 1998. The energetic value of nonstarch polysaccharides in 
relation to physical activity in group-housed growing pigs. Journal of Animal Sciences 76, 3016-3023

SHI, X.S. \& Noblet, J., 1993a. Digestible and metabolizable energy values of ten feed ingredients in growing pigs fed ad libitum and sows fed at maintenance level; comparative contribution of the hindgut. Animal Feed Science and Technology 42, 223-236

SHI, X.S. \& NoBlet, J., 1993b. Contribution of the hindgut to digestion of diets in growing pigs and adult sows; effect of diet composition. Livestock Production Science 34, 237235

Shier, N.W.; Kelman, I.; Dunson, J.W., 1984. A comparison of crude protein, moisture, ash and crop yield between organic and conventionally grown wheat. Nutrition Reports International $30(1), 71-76$

SteINECK, O. \& LIEBHARD, P., 1984. Qualität und Ertrag von Brotgetreide aus naturwissenschaftlich-biologischer und alternativ-biologischer Pflanzenproduktion. Allgemeiner Mühlen-Markt 85, 35-40

Story, J.A.; Watterson, J.J.; MAtheson, H.B.; Furumoto, E.J., 1990. Dietary fiber and bile acid metabolism. In: FURDA, I. \& BRINE, C.J. (Eds.), New developments in dietary fibre: physiological, physiochemical and analytical aspects. Advances in experimental medicine and biology, Vol.270, Plenum Press, New York, London

WILLIAMS, C., 2002. Nutritional quality of organic food: Shades of grey or shades of green? Proceedings of the Nutrition Society 61 (1), 19-24

WiSKER, E.\& FELDHEIM, W., 1992. Faecal bulking and energy value of dietary fibre. In: SchweIzer, T.F. \& EDWARDS, C.A. (Eds.), Dietary fibre: A component of food: Nutritional function in health and desease. ILSI Human Nutrition Reviews. SpringerVerlag, London, 233-246

Woese, K.; Lange, D.; Boess, C.; BöGL, K.W., 1995. Ökologisch und konventionell erzeugte Lebensmittel im Vergleich. Eine Literaturstudie. Teil I+II, BGVV Heft 5, Bundesinstitut für gesundheitlichen Verbraucherschutz und Veterinärmedizin, Berlin.

Woese, K.; Lange, D.; Boess, C.; BöGL, K.W., 1997. A comparison of organically and conventionally grown foods- results from a review of the relevant literature. Journal of the Science of Food and Agriculture 74, 281-293

Wolfson, J.L. \& ShEARER, G., 1981. Amino acid composition of grain protein of maize grown with or without pesticides and standard commercial fertilizers. Agronomy Journal 73, 611-613

WORTHINGTON, V., 1998. Effect of agricultural methods on nutritional quality: a comparison of organic with conventional crops. Alternative Therapies 4, 58-68 
Zaharia, V.; Varzescu, M.; Duavadi, I.; Newman, E.; Egnor, R.W.; AleXanderChacko, J.; Charney, A.N., 2001. Effects of short chain fatty acids on colonic $\mathrm{Na}^{+}$absorption and enzyme activity. Comparative biochemistry and physiology, Part A, Molecular and integrative physiology 128 (2), 335-347

ZERVAS, S.\& ZIJLSTRA, R.-T., 2002. Effects of dietary protein and fermentable fiber on nitrogen excretion patterns and plasma urea in growing pigs. Journal of animal science 80 (12), 3247-56

Zhao, X.; Jørgensen, H.; EgGum, B.O., 1995. The influence of dietary fibre on body composition, visceral organ weight, digestibility and energy balance in rats housed in different Thermal environments. British Journal of nutrition 73, 687-699 


\section{APPENDIX}

\section{Appendix Study 1}

Table 1: Means of protein content (\% DM) in different plant species.

\begin{tabular}{|l|l|l|l|}
\hline \multicolumn{1}{|c|}{ Plant species } & \multicolumn{1}{|c|}{ Cultivation } & Mean & SD \\
\hline \multirow{2}{*}{ Wheat $(n=16)$} & conventional & 12.62 & 0.99 \\
\cline { 2 - 4 } & organic & 10.09 & 0.91 \\
\hline \multirow{2}{*}{ Barley $(n=6)$} & conventional & 13.26 & 0.36 \\
\cline { 2 - 4 } & organic & 11.68 & 0.35 \\
\hline \multirow{2}{*}{ Faba Beans $(n=6)$} & conventional & 29.31 & 2.53 \\
\cline { 2 - 4 } & organic & 27.35 & 1.42 \\
\hline
\end{tabular}

Table 2: Means of NDF content (\% DM) in different plant species.

\begin{tabular}{|l|l|c|c|}
\hline \multicolumn{1}{|c|}{ Plant species } & \multicolumn{1}{|c|}{ Cultivation } & Mean & SD \\
\hline \multirow{2}{*}{ Wheat $(n=16)$} & conventional & 8.79 & 0.49 \\
\cline { 2 - 4 } & organic & 9.48 & 0.51 \\
\hline \multirow{2}{*}{ Barley $(n=6)$} & conventional & 13.68 & 0.77 \\
\cline { 2 - 4 } & organic & 14.12 & 0.89 \\
\hline \multirow{2}{*}{ Faba Beans $(n=6)$} & conventional & 15.04 & 2.40 \\
\cline { 2 - 4 } & organic & 16.85 & 3.47 \\
\hline
\end{tabular}

Table 3: Means of ADF content (\% DM) in different plant species.

\begin{tabular}{|l|l|c|c|}
\hline \multicolumn{1}{|c|}{ Plant species } & \multicolumn{1}{c|}{ Cultivation } & Mean & SD \\
\hline \multirow{2}{*}{ Wheat $(\mathrm{n}=16)$} & conventional & 2.54 & 0.37 \\
\cline { 2 - 4 } & organic & 2.71 & 0.35 \\
\hline \multirow{2}{*}{ Barley $(\mathrm{n}=6)$} & conventional & 4.64 & 0.28 \\
\cline { 2 - 4 } & organic & 4.88 & 0.27 \\
\hline \multirow{2}{*}{ Faba Beans $(\mathrm{n}=6)$} & conventional & 11.39 & 2.02 \\
\cline { 2 - 4 } & organic & 10.68 & 1.86 \\
\hline
\end{tabular}




\section{Appendix Study 2}

Table 4: Amino acid content in the diets.

\begin{tabular}{|l|c|c|c|c|}
\hline & \multicolumn{2}{|c|}{ Basal diet } & \multicolumn{2}{c|}{ SBP diet } \\
\hline Amino acid & AS (\% DM) & AS (\% CP) & AS (\% DM) & AS (\% CP) \\
\hline Methionine & 0.47 & 1.91 & 0.41 & 1.87 \\
\hline Cysteine & 0.43 & 1.76 & 0.38 & 3.76 \\
\hline Methionine+Cysteine & 0.90 & 3.67 & 0.79 & 5.85 \\
\hline Lysine & 1.43 & 5.82 & 1.27 & 4.15 \\
\hline Threonine & 1.01 & 4.11 & 0.90 & 5.72 \\
\hline Arginine & 1.44 & 5,86 & 1.24 & 4.02 \\
\hline Isoleucine & 0.99 & 4.05 & 0.87 & 7.61 \\
\hline Leucine & 1.89 & 7.70 & 1.65 & 4.81 \\
\hline Valin & 1.17 & 4.78 & 1.04 & 2.45 \\
\hline Histidine & 0.59 & 2.41 & 0.53 & 5.21 \\
\hline Phenylalanine & 1.31 & 5.33 & 1.13 & 4.29 \\
\hline Glycine & 1.06 & 4.31 & 0.93 & 5.04 \\
\hline Serine & 1.24 & 5.03 & 1.09 & 6.36 \\
\hline Proline & 1.60 & 6.52 & 4.13 & 4.28 \\
\hline Alanine & 1.04 & 4.24 & 0.92 & 9.27 \\
\hline Aspartic acid & 2.29 & 9.34 & 2.01 & 18.89 \\
\hline Glutamic acid & 4.79 & 19.53 & 4.09 & \\
\hline
\end{tabular}

Table 5: Influence of diet and pig breed on nutrient intake and fecal excretion $\left(\mathrm{mg} / \mathrm{d}^{*} \mathrm{~kg}^{0,75}\right)$.

\begin{tabular}{|c|c|c|c|c|c|c|c|}
\hline & \multicolumn{2}{|c|}{ Diet } & \multicolumn{3}{|c|}{ Breed } & \multirow[b]{2}{*}{$\begin{array}{l}\text { Inter- } \\
\text { action }\end{array}$} & \multirow[b]{2}{*}{ SEM } \\
\hline & $\begin{array}{c}\text { Basal } \\
(n=18)\end{array}$ & $\begin{array}{c}\text { SBP } \\
(n=18)\end{array}$ & $\begin{array}{c}\mathbf{S H} \\
(n=12)\end{array}$ & $\begin{array}{c}\text { BB } \\
(n=12)\end{array}$ & $\begin{array}{c}\text { CB } \\
(n=12)\end{array}$ & & \\
\hline intake & & & & & & & \\
\hline DM & $69.70^{\mathrm{a}}$ & $85.49^{b}$ & 78.09 & 77.34 & 77.35 & 0.092 & 1.354 \\
\hline OM & $66.31^{\mathrm{a}}$ & $80.80^{b}$ & 74.02 & 73.31 & 73.32 & 0.091 & 1.244 \\
\hline $\mathrm{CP}$ & $16.82^{a}$ & $18.06^{b}$ & 17.54 & 17.38 & 17.39 & 0.090 & 0.116 \\
\hline $\mathrm{EE}$ & $2.70^{\mathrm{a}}$ & $2.80^{b}$ & 2.76 & 2.75 & 2.75 & 0.145 & 0.010 \\
\hline $\mathrm{CF}$ & $2.27^{\mathrm{a}}$ & $4.97^{\mathrm{b}}$ & 3.66 & 3.60 & 3.60 & 0.076 & 0.229 \\
\hline $\mathrm{CA}$ & $3.40^{\mathrm{a}}$ & $4.76^{\mathrm{b}}$ & 4.07 & 4.08 & 4.08 & 0.698 & 0.115 \\
\hline $\mathrm{NfE}$ & $44.52^{\mathrm{a}}$ & $54.96^{\mathrm{b}}$ & 50.06 & 49.58 & 49.58 & 0.092 & 0.895 \\
\hline $\begin{array}{l}\text { Fecal } \\
\text { excretion }\end{array}$ & & & & & & & \\
\hline DM & $9.63^{\mathrm{a}}$ & $14.51^{\mathrm{b}}$ & 12.35 & 12.06 & 11.80 & 0.463 & 0.444 \\
\hline OM & $8.05^{\mathrm{a}}$ & $12.08^{b}$ & 10.27 & 10.02 & 9.91 & 0.426 & 0.369 \\
\hline $\mathrm{CP}$ & $2.14^{\mathrm{a}}$ & $3.64^{\mathrm{b}}$ & 2.82 & 2.98 & 2.87 & 0.480 & 0.147 \\
\hline $\mathrm{EE}$ & $0.96^{\mathrm{a}}$ & $1.26^{\mathrm{b}}$ & 1.12 & 1.15 & 1.06 & 0.272 & 0.032 \\
\hline $\mathrm{CF}$ & $1.53^{\mathrm{a}}$ & $2.27^{\mathrm{b}}$ & 2.01 & 1.78 & 1.91 & 0.153 & 0.068 \\
\hline $\mathrm{CA}$ & $1.57^{\mathrm{a}}$ & $2.39^{b}$ & $2.08^{b}$ & $1.96^{\mathrm{ab}}$ & $1.89^{\mathrm{a}}$ & 0.721 & 0.074 \\
\hline $\mathrm{NfE}$ & $3.49^{\mathrm{a}}$ & $5.10^{\mathrm{b}}$ & 4.33 & 4.33 & 4.23 & 0.531 & 0.153 \\
\hline
\end{tabular}


Table 6: Influence of diet and pig breed on mineral balances $\left(\mathrm{mg} / \mathrm{d}^{*} \mathrm{~kg}^{0,75}\right)$.

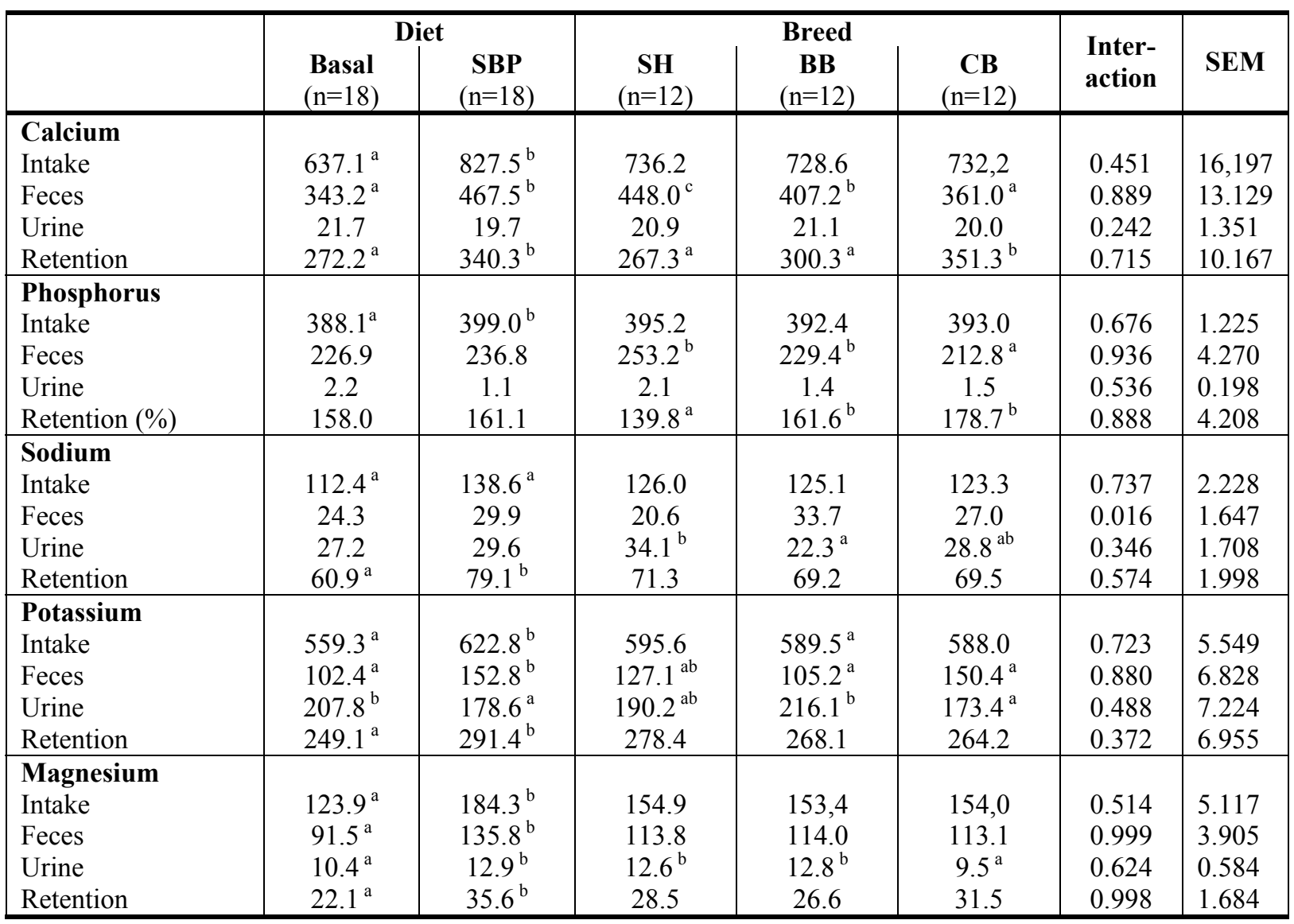

Different superscripts within the same row show significant differences $(\mathrm{p}<0.05)$.

\section{Appendix Study 3}

Table 7: Influence of diet and pig breed on SCFA production.

\begin{tabular}{|l|c|c|c|c|c|c|c|}
\hline & \multicolumn{2}{|c|}{ Diet } & \multicolumn{3}{c|}{ Breed } & Inter- & SEM \\
& $\begin{array}{c}\text { Basal } \\
(\mathrm{n}=9)\end{array}$ & $\begin{array}{c}\text { SBP } \\
(\mathrm{n}=9)\end{array}$ & $\begin{array}{c}\text { SH } \\
(\mathrm{n}=6)\end{array}$ & $\begin{array}{c}\text { BB } \\
(\mathrm{n}=6)\end{array}$ & $\begin{array}{c}\text { CB } \\
(\mathrm{n}=6)\end{array}$ & $\begin{array}{c}\text { Interion } \\
\text { action }\end{array}$ & SEM \\
\hline Acetate & 3.28 & 4.26 & 3.80 & 4.06 & 3.46 & 0.013 & 0.168 \\
Propionate & 1.85 & 2.08 & 1.97 & 1.96 & 1.96 & 0.003 & 0.050 \\
Butyrate & 0.57 & 0.55 & 0.53 & 0.64 & 0.51 & 0.025 & 0.019 \\
\hline
\end{tabular}

Table 8: Influence of diet and pig breed on $\mathrm{pH}$ value and redox potential.

\begin{tabular}{|c|c|c|c|c|c|c|c|}
\hline & \multicolumn{2}{|c|}{ Diet } & \multicolumn{3}{|c|}{ Breed } & \multirow{2}{*}{$\begin{array}{l}\text { Inter- } \\
\text { action }\end{array}$} & \multirow[b]{2}{*}{ SEM } \\
\hline & $\begin{array}{l}\text { Basal } \\
(\mathrm{n}=9)\end{array}$ & $\begin{array}{c}\text { SBP } \\
(\mathrm{n}=9)\end{array}$ & $\begin{array}{c}\text { SH } \\
(\mathrm{n}=6)\end{array}$ & $\begin{array}{c}\text { BB } \\
(n=6)\end{array}$ & $\begin{array}{c}\mathbf{C B} \\
(\mathrm{n}=6)\end{array}$ & & \\
\hline $\begin{array}{l}\mathrm{pH} \\
\text { Redox potential }\end{array}$ & $\begin{array}{c}6.60 \\
103.96^{\mathrm{a}}\end{array}$ & $\begin{array}{c}6.51 \\
154.13^{b}\end{array}$ & $\begin{array}{c}6.53 \\
-135.87^{a}\end{array}$ & $\begin{array}{c}6.53 \\
-120.83^{b}\end{array}$ & $\begin{array}{c}6.59 \\
-130.43^{a}\end{array}$ & $\begin{array}{l}0.005 \\
0.974\end{array}$ & $\begin{array}{l}0.020 \\
6.360\end{array}$ \\
\hline
\end{tabular}

Different superscripts within the same row show significant differences $(p<0.05)$. 


\section{Appendix Study 5}

Table 9: Short circuit current in jejunal mucosa $\left(\mu \mathrm{Eq} / \mathrm{cm}^{2} / \mathrm{h}\right)$. (ch: chamber of the Ussing chamber apparatus)

\begin{tabular}{|c|c|c|c|c|c|c|c|c|c|c|c|}
\hline \multirow{7}{*}{$\begin{array}{l}\text { SH } \\
\text { Pig }\end{array}$} & & \multicolumn{5}{|c|}{ Basal diet } & \multicolumn{5}{|c|}{ SBP diet } \\
\hline & & Ch 1 & Ch 2 & Ch 3 & Mean & SD & Ch 1 & Ch 2 & Ch 3 & Mean & $\mathrm{SD}$ \\
\hline & Racal & $-\cap 11$ & ก15 & $\cap 67$ & ก 24 & $\cap \Delta 0$ & 024 & $n 62$ & 117 & ก 7n & 020 \\
\hline & $\mathrm{m} .0 .5 \mathrm{mM}$ & 0.37 & 0.33 & 0.45 & 0.38 & 0.06 & 0.41 & 0.23 & 0.45 & 0.36 & 0.12 \\
\hline & $\mathrm{m}: 2.0 \mathrm{mM}$ & 0.89 & 0.63 & 0.9 & 0.81 & 0.15 & 0.85 & 0.71 & 1.04 & 0.87 & 0.17 \\
\hline & $\mathrm{m}: 4.0 \mathrm{mM}$ & 1.19 & 0.82 & 1.16 & 1.06 & 0.21 & 1.08 & 1.12 & 1.27 & 1.16 & 0.10 \\
\hline & $\mathrm{m}: 10.0$ & 1.30 & 1.04 & 1.42 & 1.25 & 0.19 & 1.45 & 1.53 & 1.6 & 1.53 & 0.08 \\
\hline
\end{tabular}

\begin{tabular}{|c|c|c|c|c|c|c|c|c|c|c|c|}
\hline \multirow{7}{*}{$\begin{array}{c}\text { BB } \\
\text { pigs }\end{array}$} & & \multicolumn{5}{|c|}{ Basal diet } & \multicolumn{5}{|c|}{ SBP diet } \\
\hline & & Ch 1 & $\mathrm{Ch} 2$ & $\mathrm{Ch} 3$ & Mean & $\mathrm{SD}$ & Ch 1 & $\mathrm{Ch} 2$ & $\mathrm{Ch} 3$ & Mean & SD \\
\hline & Basal & $0 \Delta 5$ & ח 75 & 122 & $n \times 1$ & 020 & 075 & ก78 & 147 & ח O8 & $n 28$ \\
\hline & m. $0.5 \mathrm{mM}$ & 0.71 & 0.41 & 0.49 & 0.54 & 0.16 & 0.03 & 0.08 & 0.22 & 0.11 & 0.10 \\
\hline & $\mathrm{m}: 2.0 \mathrm{mM}$ & 1.53 & 0.85 & 1.27 & 1.22 & 0.34 & 0.11 & 0.12 & 0.41 & 0.21 & 0.17 \\
\hline & $\mathrm{m}: 4.0 \mathrm{mM}$ & 1.97 & 1.04 & 1.68 & 1.56 & 0.48 & 0.22 & 0.23 & 0.63 & 0.36 & 0.23 \\
\hline & $\mathrm{m}: 10.0$ & 2.46 & 1.3 & 2.2 & 1.99 & 0.61 & 0.59 & 0.79 & 1.12 & 0.83 & 0.27 \\
\hline
\end{tabular}

\begin{tabular}{|c|c|c|c|c|c|c|c|c|c|c|c|}
\hline \multirow{7}{*}{$\begin{array}{c}\text { CB } \\
\text { pigs }\end{array}$} & & \multicolumn{5}{|c|}{ Basal diet } & \multicolumn{5}{|c|}{ SBP diet } \\
\hline & & Ch 1 & Ch 2 & Ch 3 & Mean & SD & Ch 1 & Ch 2 & Ch 3 & Mean & SD \\
\hline & Basal & 062 & ก 78 & $2 n 1$ & 114 & n 76 & $n 86$ & $n 86$ & 127 & $1 \cap n$ & $\cap 24$ \\
\hline & m. $0.5 \mathrm{mM}$ & 0.60 & 0.79 & 1.05 & 0.81 & 0.23 & 0.18 & 0.26 & 0.52 & 0.32 & 0.18 \\
\hline & $\mathrm{m}: 2.0 \mathrm{mM}$ & 1.31 & 1.76 & 2.69 & 1.92 & 0.70 & 0.82 & 0.71 & 1.34 & 0.96 & 0.34 \\
\hline & $\mathrm{m}: 4.0 \mathrm{mM}$ & 1.68 & 2.58 & 3.62 & 2.63 & 0.97 & 1.75 & 1.34 & 2.24 & 1.78 & 0.45 \\
\hline & $\mathrm{m}: 10.0$ & 2.02 & 3.73 & 4.82 & 3.52 & 1.41 & 3.62 & 3.47 & 3.39 & 3.49 & 0.12 \\
\hline
\end{tabular}


Table 10: Short circuit current in the colon mucosa $\left(\mu \mathrm{Eq} / \mathrm{cm}^{2} / \mathrm{h}\right)$.

\begin{tabular}{|c|c|c|c|c|c|c|c|c|c|c|c|}
\hline \multirow{7}{*}{$\begin{array}{c}\text { SH } \\
\text { pigs }\end{array}$} & & \multicolumn{5}{|c|}{ Basal diet } & \multicolumn{5}{|c|}{ SBP diet } \\
\hline & & Ch.7 & Ch. 8 & Ch 9 & Mean & $\mathrm{SD}$ & Ch.7 & Ch. 8 & Ch 9 & Mean & $\mathrm{SD}$ \\
\hline & Racal & n 56 & 007 & $n 57$ & $\cap 68$ & 025 & 117 & 127 & ก 78 & $1 \mathrm{nK}$ & ก)5 \\
\hline & m. $0.5 \mathrm{mM}$ & 0.00 & 0.11 & 0.08 & 0.06 & 0.06 & 0.07 & 0.04 & 0.00 & 0.04 & 0.04 \\
\hline & $\mathrm{m}: 2.0 \mathrm{mM}$ & 0.00 & 0.34 & 0.07 & 0.14 & 0.18 & 0.30 & 0.18 & 0.34 & 0.27 & 0.08 \\
\hline & $\mathrm{m}: 4.0 \mathrm{mM}$ & 0.00 & 0.41 & 0.04 & 0.15 & 0.23 & 0.33 & 0.26 & 0.38 & 0.32 & 0.06 \\
\hline & $\mathrm{m}: 10.0$ & -0.08 & 0.41 & 0.07 & 0.13 & 0.25 & 0.30 & 0.18 & 0.30 & 0.26 & 0.07 \\
\hline
\end{tabular}

\begin{tabular}{|c|c|c|c|c|c|c|c|c|c|c|c|}
\hline \multirow{7}{*}{$\begin{array}{c}\text { BB } \\
\text { pigs }\end{array}$} & & \multicolumn{5}{|c|}{ Basal diet } & \multicolumn{5}{|c|}{ SBP diet } \\
\hline & & Ch.7 & Ch. 8 & Ch 9 & Mean & SD & Ch.7 & Ch. 8 & Ch 9 & Mean & SD \\
\hline & Racal & 007 & 111 & ก5? & ก 87 & $\cap 21$ & n 71 & 111 & 002 & ก 07 & ก)1 \\
\hline & $\mathrm{m} .0 .5 \mathrm{mM}$ & 0.00 & 0.04 & -0.04 & 0.00 & 0.04 & -0.04 & 0.04 & 0.00 & 0.00 & 0.04 \\
\hline & $\mathrm{m}: 2.0 \mathrm{mM}$ & 0.19 & 0.15 & 0.04 & 0.13 & 0.08 & 0 & 0.15 & 0.08 & 0.08 & 0.08 \\
\hline & $\mathrm{m}: 4.0 \mathrm{mM}$ & 0.26 & 0.22 & 0.00 & 0.16 & 0.14 & 0.04 & 0.15 & 0.11 & 0.10 & 0.06 \\
\hline & $\mathrm{m}: 10.0$ & 0.26 & 0.22 & -0.04 & 0.15 & 0.16 & 0.04 & 0.11 & 0.04 & 0.06 & 0.04 \\
\hline
\end{tabular}

\begin{tabular}{|c|c|c|c|c|c|c|c|c|c|c|c|}
\hline \multirow{7}{*}{$\begin{array}{c}\text { CB } \\
\text { pigs }\end{array}$} & & \multicolumn{5}{|c|}{ Basal diet } & \multicolumn{5}{|c|}{ SBP diet } \\
\hline & & Ch.7 & Ch.8 & Ch 9 & Mean & $\mathrm{SD}$ & Ch.7 & Ch. 8 & Ch 9 & Mean & SD \\
\hline & Racal & $1 \cap 8$ & $n$ on & $n 24$ & ก 77 & ก 20 & $1 \mathrm{n} 4$ & 116 & 057 & n01 & 024 \\
\hline & $\mathrm{m} \cdot 0.5 \mathrm{mM}$ & 0.00 & 0.03 & 0.03 & 0.02 & 0.02 & 0.00 & 0.00 & 0.00 & 0.00 & 0.00 \\
\hline & $\mathrm{m}: 2.0 \mathrm{mM}$ & 0.00 & 0.03 & 0.14 & 0.06 & 0.07 & 0.08 & -0.04 & -0.07 & -0.01 & 0.08 \\
\hline & $\mathrm{m}: 4.0 \mathrm{mM}$ & 0.04 & 0.03 & 0.18 & 0.08 & 0.08 & 0.04 & -0.08 & -0.07 & -0.04 & 0.07 \\
\hline & $\mathrm{m}: 10.0$ & -0.04 & 0.03 & 0.29 & 0.09 & 0.17 & 0.04 & -0.08 & -0.07 & -0.04 & 0.07 \\
\hline
\end{tabular}


Table 11: Tissue conductance in the jejunal mucosa $\left(\mathrm{mS} / \mathrm{cm}^{2}\right)$.

\begin{tabular}{|c|c|c|c|c|c|c|c|c|c|c|c|}
\hline \multirow{7}{*}{$\begin{array}{l}\text { SH } \\
\text { pigs }\end{array}$} & & \multicolumn{5}{|c|}{ Basal diet } & \multicolumn{5}{|c|}{ SBP diet } \\
\hline & & $\mathrm{Ch} 1$ & $\mathrm{Ch} 2$ & $\mathrm{Ch} 3$ & Mean & $\mathrm{SD}$ & Ch 1 & $\mathrm{Ch} 2$ & $\mathrm{Ch} 3$ & Mean & $\mathrm{SD}$ \\
\hline & Racal & 145 & 157 & 110 & 1287 & 174 & 65 & $1 \cap 0$ & 85 & 862 & $29 n$ \\
\hline & $\mathrm{m} .0 .5 \mathrm{mM}$ & -0.7 & 0.4 & 1.0 & 0.23 & 0.86 & 0.8 & 1.1 & 1.0 & 0.97 & 0.15 \\
\hline & $\mathrm{m}: 2.0 \mathrm{mM}$ & -0.6 & 3.5 & 3.0 & 1.97 & 2.24 & 3.3 & 3.7 & 2.7 & 3.23 & 0.50 \\
\hline & $\mathrm{m}: 4.0 \mathrm{mM}$ & -0.7 & 4.6 & 3.6 & 2.50 & 2.82 & 4.5 & 4.4 & 3.6 & 4.17 & 0.49 \\
\hline & $\mathrm{m}: 10.0 \mathrm{mM}$ & -1.2 & 5.5 & 4.0 & 2.77 & 3.52 & 5.0 & 4.7 & 4.0 & 4.57 & 0.51 \\
\hline
\end{tabular}

\begin{tabular}{|c|c|c|c|c|c|c|c|c|c|c|c|}
\hline \multirow{7}{*}{$\begin{array}{c}\text { BB } \\
\text { pigs }\end{array}$} & & \multicolumn{5}{|c|}{ Basal diet } & \multicolumn{5}{|c|}{ SBP diet } \\
\hline & & Ch 1 & Ch 2 & Ch 3 & Mean & $\mathrm{SD}$ & Ch 1 & $\mathrm{Ch} 2$ & Ch 3 & Mean & $\mathrm{SD}$ \\
\hline & Racal & 126 & $11 \cap$ & 125 & $177 n$ & 147 & 101 & 326 & 328 & 2717 & 766 \\
\hline & $\mathrm{m} .0 .5 \mathrm{mM}$ & 0.6 & 1.0 & 0.9 & 0.83 & 0.21 & 0.5 & 0.2 & -1.5 & -0.27 & 1.08 \\
\hline & $\mathrm{m}: 2.0 \mathrm{mM}$ & 2.6 & 3.2 & 3.7 & 3.17 & 0.55 & 1.3 & 0.7 & -2.4 & -0.13 & 1.99 \\
\hline & $\mathrm{m}: 4.0 \mathrm{mM}$ & 3.4 & 3.9 & 5.2 & 4.17 & 0.93 & 2.7 & 2.0 & -1.7 & 1.00 & 2.36 \\
\hline & $\mathrm{m}: 10.0 \mathrm{mM}$ & 4.0 & 4.0 & 5.7 & 4.57 & 0.98 & 2.8 & 1.3 & -0.8 & 1.10 & 1.81 \\
\hline
\end{tabular}

\begin{tabular}{|c|c|c|c|c|c|c|c|c|c|c|c|}
\hline \multirow{7}{*}{$\begin{array}{c}\text { CB } \\
\text { pigs }\end{array}$} & & \multicolumn{5}{|c|}{ Basal diet } & \multicolumn{5}{|c|}{ SBP diet } \\
\hline & & $\mathrm{Ch} 1$ & Ch 2 & $\mathrm{Ch} 3$ & Mean & SD & Ch 1 & $\mathrm{Ch} 2$ & Ch 3 & Mean & $\mathrm{SD}$ \\
\hline & Basal & 14.0 & 30.5 & 25.2 & 23.23 & 8.42 & 35.2 & 34.1 & 26.6 & 31.97 & 4.68 \\
\hline & $\mathrm{m} .0 .5 \mathrm{mM}$ & 1.0 & 0.4 & 1.8 & 1.07 & 0.70 & 0.0 & -1.9 & 1.5 & -0.13 & 1.70 \\
\hline & $\mathrm{m}: 2.0 \mathrm{mM}$ & 2.5 & 0.2 & 2.3 & 1.67 & 1.27 & -0.4 & 0.6 & 4.4 & 1.53 & 2.53 \\
\hline & $\mathrm{m}: 4.0 \mathrm{mM}$ & 3.2 & 0.2 & 2.5 & 1.97 & 1.57 & 0.3 & 1.3 & 7.4 & 3.00 & 3.84 \\
\hline & $\mathrm{m}: 10.0 \mathrm{mM}$ & 3.5 & 0.2 & 3.7 & 2.47 & 1.97 & -0.9 & 0.3 & 5.9 & 1.77 & 3.63 \\
\hline
\end{tabular}


Table 12: Tissue conductance in the colon mucosa $\left(\mathrm{mS} / \mathrm{cm}^{2}\right)$.

\begin{tabular}{|c|c|c|c|c|c|c|c|c|c|c|c|}
\hline \multirow{7}{*}{$\begin{array}{c}\text { SH } \\
\text { pigs }\end{array}$} & & \multicolumn{5}{|c|}{ Basal diet } & \multicolumn{5}{|c|}{ SBP diet } \\
\hline & & Ch.7 & Ch. 8 & Ch 9 & Mean & $\mathrm{SD}$ & Ch.7 & Ch. 8 & Ch 9 & Mean & SD \\
\hline & Racal & 227 & 187 & 211 & 9082 & 751 & 121 & $1 n$ & 170 & $17 n n$ & 172 \\
\hline & m.0.5mM & -0.2 & 0.1 & 0.5 & 0.13 & 0.35 & 0.1 & 0.2 & 0.0 & 0.10 & 0.10 \\
\hline & $\mathrm{m}: 2.0 \mathrm{mM}$ & -1.4 & -2.2 & -0.7 & -1.43 & 0.75 & 0.1 & 0.2 & -0.4 & -0.03 & 0.32 \\
\hline & $\mathrm{m}: 4.0 \mathrm{mM}$ & -2.2 & -3.1 & -1.3 & -2.20 & 0.90 & 0.0 & 0.1 & -0.6 & -0.17 & 0.38 \\
\hline & $\mathrm{m}: 10.0$ & -3.4 & -4.3 & -1.6 & -3.10 & 1.37 & -0.4 & 0.0 & -1.5 & -0.63 & 0.78 \\
\hline
\end{tabular}

\begin{tabular}{|c|c|c|c|c|c|c|c|c|c|c|c|}
\hline \multirow{7}{*}{$\begin{array}{c}\text { BB } \\
\text { pigs }\end{array}$} & & \multicolumn{5}{|c|}{ Basal diet } & \multicolumn{5}{|c|}{ SBP diet } \\
\hline & & Ch.7 & Ch. 8 & Ch 9 & Mean & $\mathrm{SD}$ & Ch.7 & Ch.8 & $\mathrm{Ch} 9$ & Mean & $\mathrm{SD}$ \\
\hline & Racal & $17 \Delta n$ & 112 & 08 & 1117 & $\begin{array}{lll}1 & 21 \\
\end{array}$ & 02 & 125 & 178 & 1152 & 104 \\
\hline & $\mathrm{m} .0 .5 \mathrm{mM}$ & -0.1 & 0.3 & 0.3 & 0.17 & 0.23 & 0.1 & 0.4 & -0.2 & 0.10 & 0.30 \\
\hline & $\mathrm{m}: 2.0 \mathrm{mM}$ & 0.6 & 0.6 & 0.8 & 0.67 & 0.12 & 0.3 & 0.2 & 0.2 & 0.23 & 0.06 \\
\hline & $\mathrm{m}: 4.0 \mathrm{mM}$ & 0.2 & 0.5 & 0.9 & 0.53 & 0.35 & 0.1 & -0.2 & -0.2 & -0.10 & 0.17 \\
\hline & $\mathrm{m}: 10.0$ & 0.2 & 0.3 & 1.1 & 0.53 & 0.49 & -0.1 & -0.5 & -0.7 & -0.43 & 0.31 \\
\hline
\end{tabular}

\begin{tabular}{|c|c|c|c|c|c|c|c|c|c|c|c|}
\hline \multirow{7}{*}{$\begin{array}{c}\text { CB } \\
\text { pigs }\end{array}$} & & \multicolumn{5}{|c|}{ Basal diet } & \multicolumn{5}{|c|}{ SBP diet } \\
\hline & & Ch.7 & Ch. 8 & Ch 9 & Mean & $\mathrm{SD}$ & Ch.7 & Ch. 8 & Ch 9 & Mean & $\mathrm{SD}$ \\
\hline & Racal & 850 & 140 & 178 & $17 \cap 7$ & 236 & 114 & 06 & 178 & 1127 & $16 n$ \\
\hline & $\mathrm{m} .0 .5 \mathrm{mM}$ & 0.3 & -1.0 & 0.0 & -0.23 & 0.68 & 0.1 & -0.2 & -0.1 & -0.07 & 0.15 \\
\hline & $\mathrm{m}: 2.0 \mathrm{mM}$ & -0.4 & 0.5 & -2.2 & -0.70 & 1.37 & 0.5 & -0.6 & -0.5 & -0.20 & 0.61 \\
\hline & $\mathrm{m}: 4.0 \mathrm{mM}$ & -0.8 & -0.8 & -2.7 & -1.43 & 1.10 & 0.7 & -1.0 & -1.0 & -0.43 & 0.98 \\
\hline & $\mathrm{m}: 10.0$ & -1.1 & -2.4 & -4.1 & -2.53 & 1.50 & 0.6 & -1.5 & -1.5 & -0.80 & 1.21 \\
\hline
\end{tabular}




\section{Appendix Study 6}

Table 13: Influence of diet and pig breed on nutrient intake and fecal excretion $\left(\mathrm{mg} / \mathrm{d}^{*} \mathrm{~kg}{ }^{0.75}\right)$.

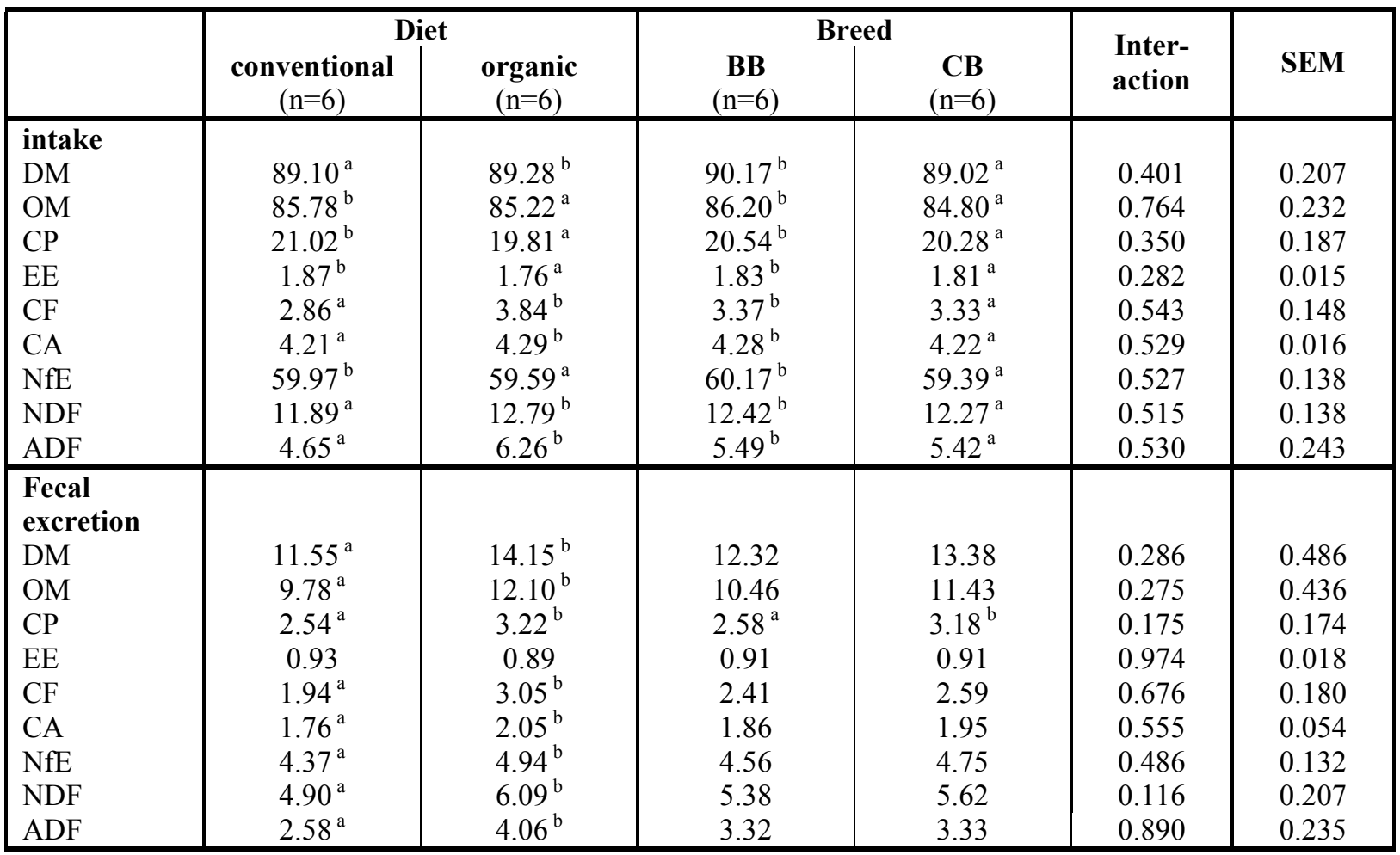




\section{Danksagung}

Herzlich bedanken möchte ich mich bei Herrn Prof. Abel für die Überlassung des Themas, die freundliche Aufnahme in die Arbeitsgruppe sowie für die nette und persönliche Betreuung.

Mein Dank gilt auch Herrn Prof. Breves für die nette Unterstützung während der Untersuchungen an der TiHo Hannover und für die Übernahme des Korreferates.

Herrn Rolf Jeromin danke ich für die Anleitung und Hilfe bei der Durchführung der Fütterungsversuche sowie der Laboranalysen.

Frau Becker, Frau Burmester, Frau Dringenberg sowie Hakan Öztürk möchte ich ganz herzlich für die Hilfe während und bei den Versuchen mit dem COSITEC sowie der Ussing Kammer an der TiHo Hannover danken.

Ulrike Meister sowie Corinna Brockmann danke ich für die Hilfe bei den Stoffwechselversuchen sowie bei zahlreichen Analysen, ebenso Dirk Berthold für die Hilfe bei den Mikrokalorimeterversuchen.

Meinen Mitdoktoranden Mom, Despal und Bernardo danke ich für die Unterstützung und auch für die vielen netten und sehr lustigen Stunden am Institut.

Meiner Tante und meinem Onkel Barbara und Gary Daniels in den USA danke ich für das geduldige Korrekturlesen.

Meinem Freund Alexander von Heimendahl möchte ich herzlich für das Ertragen zahlreicher Krisen beim Schreiben der Arbeit und für seine Unterstützung danken.

Meinen Freunden in Göttingen und sonst wo in der Welt danke ich für ihre Ratschläge, sowie für die nette gemeinsame Zeit in Göttingen.

Nicht zuletzt möchte ich meinen Eltern für die finanzielle und anderweitige Unterstützung danken. 


\section{Lebenslauf}

\section{Persönliche Daten}

Name:

Elke Meister

Geburtsdatum:

05. September 1974

Geburtsort:

Langen/ Offenbach

Staatsangehörigkeit:

Deutsch

\section{Ausbildung}

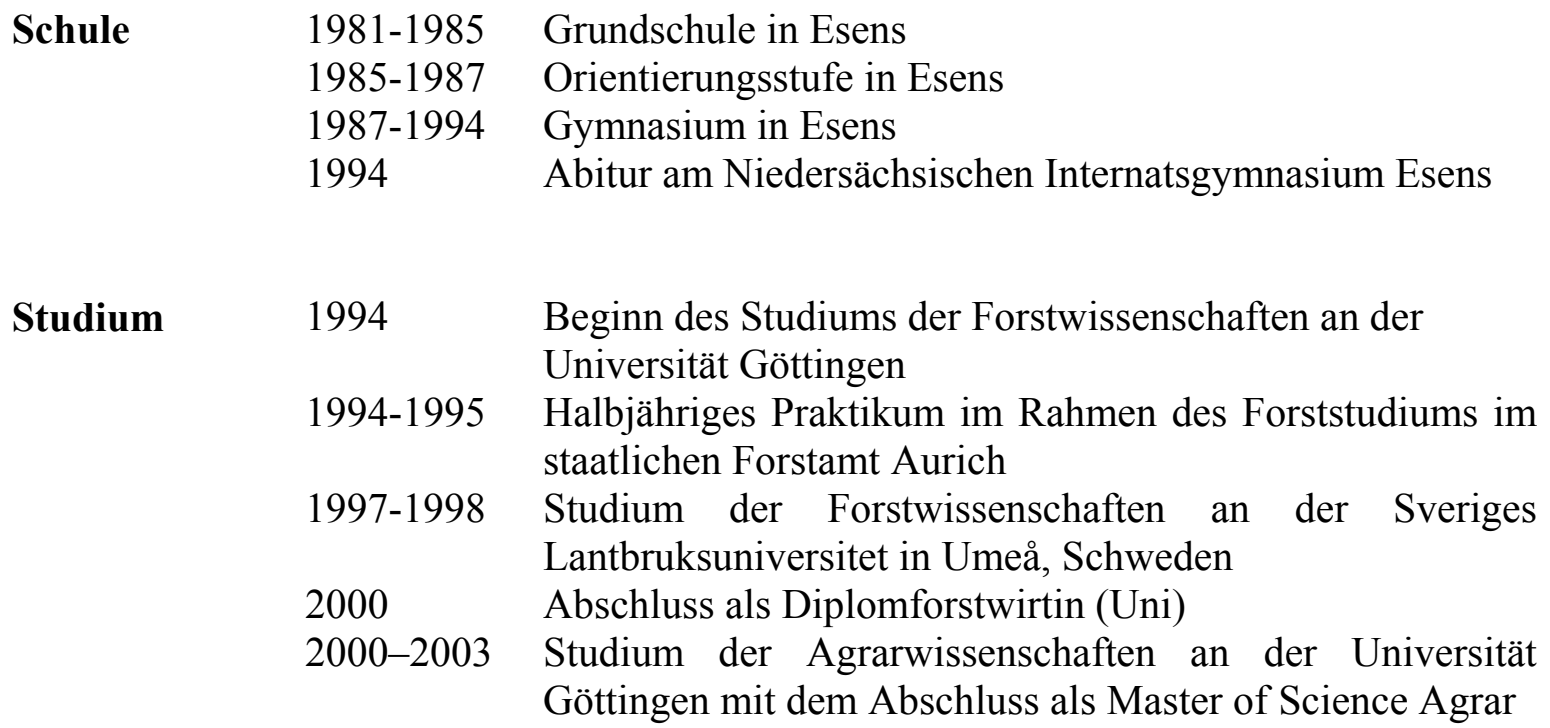

Wissenschaftl. 2002-2004 Wissenschaftliche Mitarbeiterin am Institut für Tätigkeit Tierphysiologie und Tierernährung der Universität Göttingen

2002-2004 Doktorandin am Institut für Tierphysiologie und Tierernährung der Universität Göttingen 